(2) norden 



\section{Arbejdspladslæring}

forudsætninger, strategi/metoder og resultater 


\section{Arbejdspladslæring}

forudsætninger, strategi/metoder og resultater

TemaNord 2007:576

(C) Nordisk Ministerråd, København 2007

ISBN 978-92-893-1557-9

Tryk: Ekspressen Tryk \& Kopicenter

Trykt på miljøvenligt papir som opfylder kravene i den nordiske miljøsvanemærkeordning. Publikationen kan bestilles på www.norden.org/order. Flere publikationer på www.norden.org/publikationer

Printed in Denmark

Nordisk Ministerråd

Store Strandstræde 18

1255 København K

Telefon (+45) 33960200

Fax (+45) 33960202

www.norden.org

\section{Nordisk Råd}

Store Strandstræde 18

1255 København K

Telefon (+45) 33960400

Fax (+45) 33111870

\section{Det nordiske samarbejde}

Det nordiske samarbejde er en af verdens mest omfattende regionale samarbejdsformer. Samarbejdet omfatter Danmark, Finland, Island, Norge og Sverige, samt de selvstyrende områder Færøerne, Grønland og Åland.

Det nordiske samarbejde er både politisk, økonomisk og kulturelt forankret, og er en vigtig medspiller i det europæiske og internationale samarbejde. Det nordiske fællesskab arbejder for et stærkt Norden i et stærkt Europa.

Det nordiske samarbejde ønsker at styrke nordiske og regionale interesser og værdier i en global omverden. Fælles værdier landene imellem er med til at styrke Nordens position som en af verdens mest innovative og konkurrencedygtige regioner. 


\section{Indholdsfortegnelse}

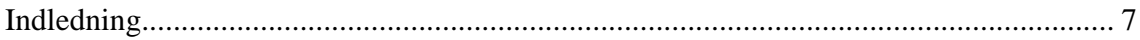

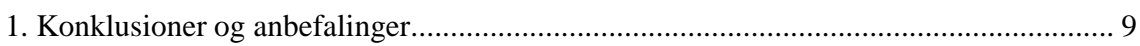

Konklusioner: Hvad kendetegner de succesfulde strategier inden for læring i

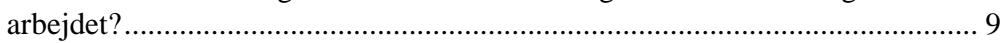

1.1 Succes faktorer: Faktorer der fremstår som bærende for „best practice“................. 9

Ad 1.1 Integration mellem formel læring og uformel læring ..................................... 11

Ad 1.2 Nært samarbejde mellem arbejdsplads og uddannelsesudbyder ...................... 13

Ad 1.3 Arbejdspladsens øverste ledelse og daglige ledelse støtter og legitimerer kompetenceudviklingstiltagene på arbejdspladsen........................................ 13

Ad 1.4 Medarbejderinvolvering ................................................................................. 14

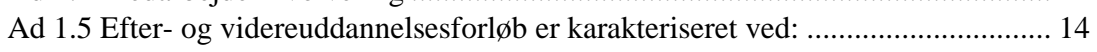

Ad 1.6 Muligheder for refleksion. Etablering af refleksionsrum................................ 15

Ad 1.7 Integration af individuel læring og organisatorisk læring: integration af individuelle udviklingsprocesser og sociale forandringsprocesser på arbejdspladsen.

Ad 1.8 Efter- og videreuddannelse og kompetenceudviklingstiltag er led i en mere omfattende strategi for udvikling af virksomheden........................................ 17

Ad 1.9 Arbejdspladsen støtter forandringer der hidrører fra kompetenceudvikling og integrerer kompetenceudvikling med rutiner inden for personaleudvikling.... 18

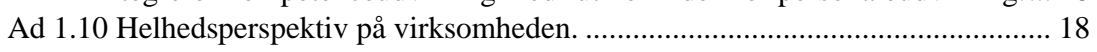

Ad 1.11 Anvendelse af vejledere og mentorer på arbejdspladsen. ............................ 19

Ad 1.12 Etablering af særlige roller på arbejdspladsen til støtte for læring i arbejdet.19

Ad 1.13 Arbejdspladsen er indrettet som et optimalt læringsmiljø for læring i arbejdet.

1.2 Konkrete modeller for best practice ................................................................. 21

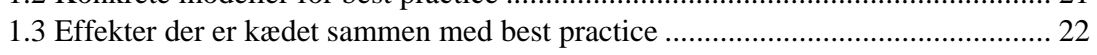

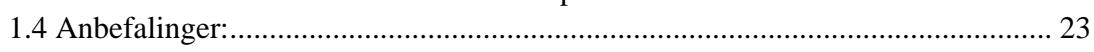

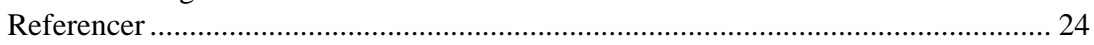

2. Læring i arbejdet - perspektiver og udgangspunkter ................................................... 25

2.1 Et uddannelsespolitisk perspektiv: Lifelong learning og kompetence begrebet i UNESCO, OECD og EU............................................................................ 25

2.2 Definitioner af grundlæggende begreber og afgrænsning af feltet ....................... 26

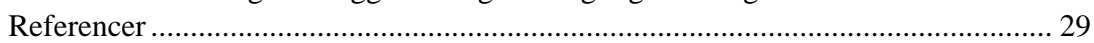

3. Det nordiske projekt: Voksnes læring i arbejdslivet ................................................... 31

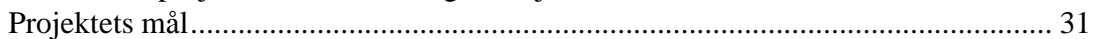

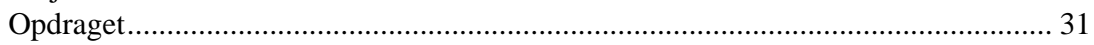

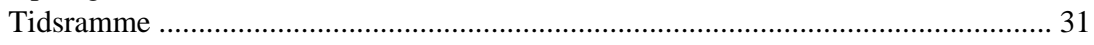

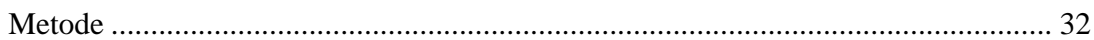

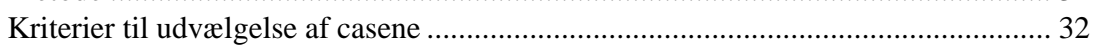

Forskningsspørgsmål.............................................................................................. 33

Gennemførelsen af projektet. Hovedfaserne i projektet har været: ........................... 33

4. Vad vet vi? En översikt av tidigare nordisk forskning om kompetens-utveckling i

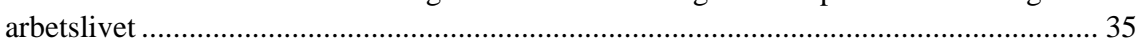

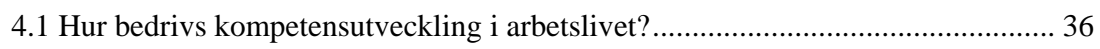

4.2 Varför satsar organisationer på kompetensutveckling? ........................................ 38

4.3 Vilka effekter kan uppnås av kompetensutveckling i organisationer?....................... 40

4.4 Vad kännetecknar framgångsrika strategier för kompetensutveckling? ................. 43

4.5 Avslutande kommentarer ................................................................................ 49

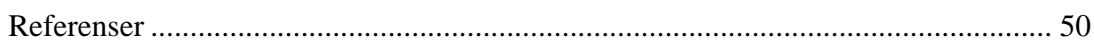


5. Seks cases fra de nordiske lande - i kort og redigeret form ...........................................5

Case 1: Læring der forbedrer praksis i arbejdet. Undervisning med interventionssigte:

at støtte arbejdspladsens forandringsprocesser

Case 2. Work smarter not harder: Udvikling af den menneskelige side af virksomheden gennem integration af læring, refleksionsprocesser, videndeling og udviklingsprocesser på virksomheden. .......................................................61 61

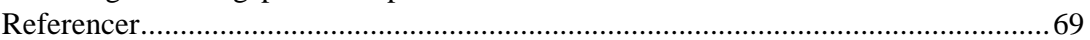

Case 3. Medarbejderuddannelse gennem medarbejderdialog ..................................... 70

Case 4. Arbetsplatslärande - ett sätt att utveckla individer och organisationer............81

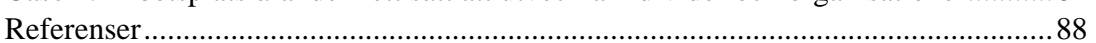

Case 5. Yrkesbaserat lärande. Projekt i Söderhamn åren 2002-2005 ........................... 89

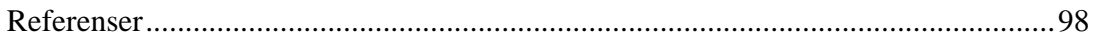

Case 6. Udvikling af en lærende omgang med arbejdet............................................99

6. Analyse af cases: Hvad karakteriserer de effektive strategier? Beskrivelse af fem

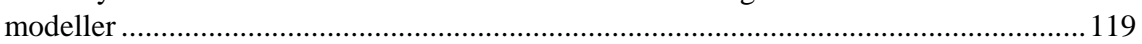

Hvordan kan best practice beskrives? Niveauer for beskrivelse af best practice .......119

Model 1: Etablering af en udviklingsorganisation uden for arbejdspladsen, og samtidig i samspil med arbejdspladsen...

Model 2: Erhvervsbaseret læring (Yrkesbaserat lärande). Etablering af samarbejde mellem en uddannelsesinstitution og en arbejdsplads, hvor arbejdspladsens praksis er udgangspunkt for integration af praksisviden og teoretisk viden. Söderhamn modellen.

Model 3: Medarbejderuddannelse gennem gap-analyse baseret på medarbejderdialog .

Model 4: E-læring og fleksibel læring på arbejdspladsen. Etablering af minilæringscentre på arbejdspladsen. ................................................................... 135

Model 5: Arbejdspladsen som ramme og læringsmiljø for medarbejdernes kompetenceudvikling. Udvikling af et læringssystem på arbejdspladsen...... 140

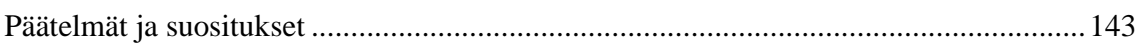

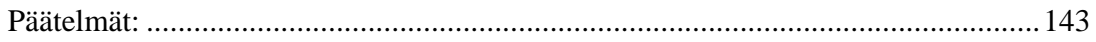

Menestystekijät: parhaiden käytäntöjen keskeiset tekijät..........................................143

Virallisen ja epävirallisen oppimisen yhdistyminen ..............................................144

Työpaikan ja koulutuksen tarjoajan läheinen yhteistyö ...........................................147

Työpaikan ylimmän ja toimeenpanevan johdon tuki ja oikeutus työpaikalla toteutettaville osaamisen kehittämistoimenpiteille .........................................147

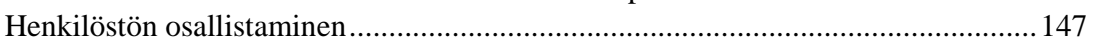

Jatko- ja täydennyskoulutuksen ominaispiirteet.................................................... 148

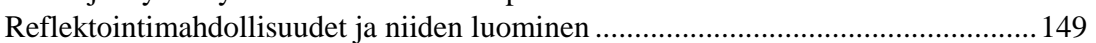

Yksilöllisen ja organisatorisen oppimisen yhdistäminen: työpaikan yksilölliset kehitysprosessit ja sosiaaliset muutosprosessit yhdistyvät.............................150

Jatko- ja täydennyskoulutus sekä osaamisen kehittämistoimenpiteet osana työpaikan

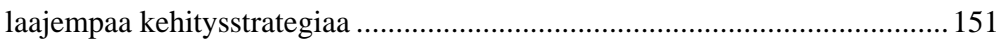

Työpaikan tuki muutoksille, jotka ovat seurausta osaamisen kehittämisestä, ja osaamisen kehittämisen yhdistäminen henkilöstön kehittämisrutiineihin......151

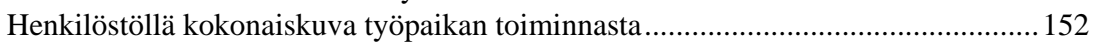

Ohjaajien ja mentorien käyttö työpaikalla .............................................................. 152

Oppimista tukevien erityisroolien luominen työpaikalla ............................................. 153

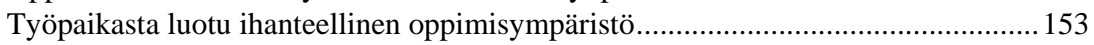

Konkreettisia malleja parhaista käytännöistä .......................................................... 154

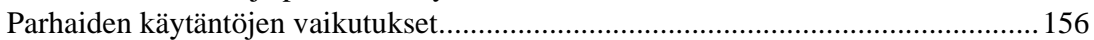

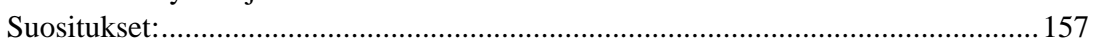

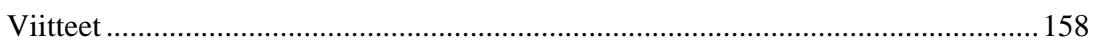




\section{Indledning}

Nordisk Ministerråds rådgivningsgruppe for nordisk Samarbejde om Voksnes Læring (SVL) har initieret et komparativt studie i de nordiske lande, af "Voksnes leering i arbejdslivet." Opdraget blev givet til Danmarks Pædagogiske Universitet som har ledet og koordineret studiet i samarbejde med Linköping Universitet/Centre for Studies of Humans, Technology and Organization. De projektansvarlige er henholdsvis lektor Steen Høyrup og professor Per-Erik Ellström. Studiet er i det væsentlige gjennomført i 2006 med afrapportering foråretvåren 2007.

Læring og kompetenceudvikling er af overordentlig stor betydning, for den enkeltes liv, for virksomhederne og for samfundet som helhed, ikke mindst i et globalt perspektiv. Fra pædagogisk forskning véd vi, at læring i praksis er hensigtsmæssig og effektiv, når det der skal læres er udførelsen af konkrete handlinger i en arbejdssammenhæng. Vi ved også at praksis alene gør det ikke, teoretisk viden er ligeledes væsentlig for udvikling af færdigheder og kompetencer. Dette har været et væsentligt udgangspunkt for studiet.

I denne sammenhæng peger megen forskning på de store potentialer arbejdspladsen har, som arena for læring. Sigtet med det foreliggende projekt er at skabe viden om, hvad der er de mest hensigtsmæssige måder at organisere læring på, med arbejdspladsen som udgangspunkt, og skabe indsigt i, hvordan vi bedst kan indrette arbejdspladser, så de samtidig er en god ramme om produktion (varer, service og viden) og et læringsmiljø, der på den mest hensigtsmæssige måde fremmer læring. Hvilke faktorer synes at være særlig vigtige mht. at støtte læring i arbejdet?

En dokumenteret viden inden for dette felt vil kunne være værdifuld for virksomhedsledere og uddannelsesansvarlige på vore arbejdspladser, og parterne omkring kompetenceudvikling af medarbejderne på arbejdspladserne. Den udviklede viden kan ligeledes være et vigtigt grundlag for samarbejde mellem partnerne, der træffer aftaler om og tilrettelægger kompetenceudvikling og efter- og videreuddannelse af medarbejderne på arbejdspladserne.

Rapporten er disponeret således, at hovedkonklusioner og anbefalinger gives direkte efter indledningen. I kapitlet: Læring i arbejdet - perspektiver og udgangspunkter bringes rapportens indhold og problematik ind i en større uddannelsespolitisk sammenhæng, og de grundlæggende begreber som livslang læring og kompetencebegrebet defineres. Herefter gives en beskrivelse af hovedtræk i det nordiske projekt, Voksnes læering $i$ arbejdslivet: opdraget, formål, metode, begrebsafklaring og gennemførelse mv. I næste kapitel "Vad ved vi? En översikt av tidligare nordisk forskning om kompetensutveckling i arbetslivet", - gives en oversigt og 
strukturering af den allerede eksisterende viden på feltet, i opdateret form. Herefter følger en præsentation af case materialet - i form af 6 cases - bearbejdet til en kort og indbyrdes sammenlignelig form. (Det fulde case materiale er ikke medtaget i denne rapport). Disse to sidstnævnte kapitler udgør datagrundlaget, på hvilket der konkluderes. I det efterfølgende kapitel redegøres for bearbejdning af og refleksioner over casematerialet, på baggrund af hvilke der udvikles fem modeller for best practice.

Rapporten er skrevet på svensk og dansk. Kapitlet "Vad ved vi? En översikt av tidligare nordisk forskning om kompetensutveckling i arbetslivet“ er udarbejdet af professor Per-Erik Ellström. De to danske cases er redigeret af lektor Steen Høyrup, og bygger på casebeskrivelser af lektor Hanne Dauer Keller, Aalborg universitet, og Steen Høyrup. Den finske case er redigeret af Steen Høyrup og bygger på en casebeskrivelse udarbejdet af ph.d.-studerende Maija Vähämäki, Turku School of Economics and Business Administration. Den norske case er udarbejdet og redigeret af amanuensis Mette Iversen, Danmarks Pædagogiske Universitet. De svenske cases er redigeret af ph.d.-studerende Erica Byström og professor Per-Erik Ellström, og bygger på bidrag fra Lennart Svensson, Malin Ljungzell, Robert Höghielm og Sven-Olaf Larsson.

Tak til alle for samarbejde og bidrag til projektet. Ligeledes tak for samarbejdet til Nordisk Ministerråds rådgivningsgruppe for nordisk Samarbejde om Voksnes Læring (SVL). 


\section{Konklusioner og anbefalinger}

Konklusioner: Hvad kendetegner de succesfulde strategier inden for læring i arbejdet?

Konklusionerne formuleres i tre afsnit:

1. Faktorer der fremstår som bærende for „best practice“

2. Konkrete modeller for best practice

3. Karakteristiske træk ved effekter af effektive strategier

\subsection{Succes faktorer: Faktorer der fremstår som bærende} for „best practice“

Et hovedtræk i konklusionerne er, at succes faktorerne der kan udpeges, er meget komplekse. De fleste succes-faktorer har således karakter af at være relationer mellem faktorer. F.eks. relationen mellem formel og uformel læring, relationen mellem individuel læring og forandringer på arbejdspladsen, mv.

Der er i nedenstående redegørelse en vis overlapning i beskrivelsen af succes faktorer. Dette skyldes at faktorerne ikke opererer som isolerede faktorer men indgår i et nært samspil med hinanden i forskellige sammenhænge. 


\section{Succes-faktorer: En oversigt}

1. Integration mellem formel læring og uformel læring

2. Nært samarbejde mellem arbejdsplads og uddannelsesudbyder

3. Arbejdspladsens ledelse støtter og legitimerer kompetenceudviklingstiltagene på arbejdspladsen

4. Medarbejderinvolvering

5. Efter- og videreuddannelsesforløb er karakteriseret ved:
5.1 Virksomhedstilpasset undervisning
5.2. Målorienteret uddannelse
5.3 Fleksibilitet
5.4 Erfaringsbaseret læring er udgangspunktet
5.5 Teori-praksis kobling som et gennemgående element
5.6 Adgang til læringsressourcer
5.7 Arbejdsformerne er dialogprægede og problemorienterede, og giver deltagerne mulighed for at være aktive, handle, eksperi- mentere og forbinde kursussituation med arbejdssituationen
5.8 Tidlig oplevelse af succes for medarbejderne

6. Muligheder for refleksion. Etablering af refleksionsrum

7. Integration af individuel læring og organisatorisk læring: integration af individuelle udviklingsprocesser og sociale forandringsprocesser på arbejdspladsen

8. Efter- og videreuddannelse og kompetenceudviklingstiltag er led i en mere omfattende strategi for udvikling af virksomheden

9. Arbejdspladsen støtter forandringer der hidrører fra kompetenceudvikling og integrerer kompetenceudvikling med rutiner inden for personaleudvikling

10. Helhedsperspektiv på virksomheden

11. Anvendelse af vejledere og mentorer på arbejdspladsen

12. Etablering af særlige roller på arbejdspladsen til at støtte læring i arbejdet

13. Arbejdspladsen er indrettet som et optimalt læringsmiljø for læring i arbejdet

13.1 Karakteristika ved arbejdsopgaverne

13.2 Støtte for laring i det daglige arbejde

13.3 En arbejdsplads læeringskultur

13.4 Virksomheden er organiseret for både produktion og laring (udvikling)

13.5 Ledelsens betydning, ledelseskompetence 


\section{Ad 1.1 Integration mellem formel læring og uformel læring ${ }^{1}$}

Formel læring er institutionaliseret læring der foregår i uddannelsesinstitutioner. Uformel læring er i denne sammenhæng læring i det daglige arbejde, hvor arbejdspladsen er læringsmiljø, hvor læring ikke behøver have et formuleret formål, og hvor den lærende muligvis ikke er sig bevidst at han/hun lærer gennem arbejdsprocessen. Den måde arbejdet er organiseret på og den måde som job udformes og forvaltes på, bestemmer ikke blot hvad der laves af hvem og hvornår, men også hvad medarbejderne lærer.

I denne sammenhæng anfører Professor Henrik Holt Larsen:

For det første er læring på jobbet (uformel læring, red.) ofte et bedre, mere effektivt, mere smidigt og billigere alternativ til at lære noget, end ved at blive sat på skolebænken (formel læring, red.). For det andet viser talrige undersøgelser, at det som folk lærer mest af, netop er læring på jobbet (Henrik Holt Larsen 2002, p. 12).

På dette punkt er denne rapports hovedkonklusion lidt anderledes:

Den mest effektive læring i arbejdet finder sted når formel og uformel læring integreres, dvs. når læring på kurser og „,æring på jobbet“ integreres.

Henrik Holt Larsen anfører dog også, at læring på jobbet som kilde til kompetenceudvikling ikke overflødiggør kurser. (Larsen, 2002, p. 12) Denne erkendelse fremgår også af den foreliggende rapport.

Med reference til rapportens terminologi kan dette også formuleres således: det mest effektive er en integration af den linecere strategi - hvor kompetenceudvikling sker i to trin, først erhverves den og efterfølgende anvendes den - og den interaktive strategi, hvor kompetence erhverves og anvendes parallelt. Den uformelle laring i det daglige arbejde integreres med planlagte uddannelsestiltag.

Denne komplekse succesfaktor for best practice inkluderer en række mere specifikke kendetegn, hvorigennem relationen og integrationen kan udmøntes:

- Ved tilrettelæggelsen af kursusforløb inddrages medarbejderne i en dialog med formulering af deres uddannelsesbehov, og deres syn på arbejdspladsens udviklingsbehov og problemer. Medarbejdernes perspektiv, erfaringer og læringsbehov udgør et vigtigt grundlag for kursustilrettelæggelsen.

- Kompetenceudviklingsprogrammer baserer sig på virksomhedens egen interne kompetence, f.eks. afklaret gennem

\footnotetext{
${ }^{1}$ Det danske begreb "Uformel læring” svarer her til det svenske begreb "informellt lärande” og det engelske udtryk "informal learning”.
} 
medarbejderudviklingssamtaler eller realkompetenceafklaringer. Voksen- og efteruddannelsestiltag er rettet imod og er skræddersyet til erkendte og formulerede behov for læring og udvikling i arbejdet.

- Uddannelsen finder sted på arbejdspladsen, eller i direkte tilknytning til arbejdspladsen, helt eller delvis inden for arbejdstiden, og deltagerne i uddannelsen udgøres af enten teams af medarbejdere, eller alle medarbejdere en enhed af arbejdspladsen, f.eks. produktionen, eller alle arbejdspladsens medarbejdere og ledere.

- Uddannelsen er designet som et samspil mellem kursusforløb og praktikførløb, hvor kursusforløbene er relativt korte i forhold til praktikforløbene, der typisk er længere.

- Kursusforløbene baserer sig på en række pædagogiske principper der tilstræber at sammenholde og integrere teoretisk viden og praksisviden (arbejdserfaringer og viden der evt. er kropsbunden og ikke sat på sproglig formel, såkaldt tavs viden)

- For de mest uddannelsesfremmede medarbejdere har det vist sig hensigtsmæssigt at det er praksis der strukturerer teorien, dvs. at det er praksis der bestemmer hvilken teori der udvælges og tidspunkterne for formidlingen af teori, og omfanget af teoriformidling. Teori læres når der i arbejdets praksis opstår behov herfor, og teoretisk viden fremstår som nødvendig for at kunne løse opgaver og imødekomme krav i arbejdet.

- Teori og praksis kan integreres ved at der både arbejdes deduktivt (formulerede teorier bruges som redskaber til at forstå og analysere praksis og arbejdsproblemer) og induktivt (formulerede erfaringer og eksempler fra arbejdet almengøres og forstås i lyset af udvalgt relevant teori). Arbejde med cases, øvelser og rollespil mv. er induktive arbejdsformer. Udgangspunkt i deltagernes erfaringer og perspektiver er et generelt induktivt princip.

- Hvor teorien er baseret på almene fag skabes mulighed for at integrere almen viden og specifik faglig viden.

- Arbejdsformerne der skal støtte udviklingen af kompetencer er dialogpræget og lægger vægt på at deltagerne er aktive, undersøgende, eksperimenterende, eksponerer og diskuterer deres holdninger og værdier, og får mulighed for at handle, enten „som om handlinger“ i kursussituationen (f.eks. i form af øvelser og rollespil) eller planlagte handlinger der efterfølgende udføres i arbejdssituationen.

- I praktikforløbene er det indbygget, at medarbejderne undersøger arbejdsforhold og problemer i arbejdet, og formulerer tanker om eller tager initiativer til forbedringer og forandringer i arbejdet. Disse momenter føres efterfølgende ind i kursusforløbet til en fælles bearbejdning, forståelse, perspektivering og almengørelse. 


\section{Ad 1.2 Nært samarbejde mellem arbejdsplads og uddannelsesudbyder}

Ovennævnte succes faktor for best practice er en afledt konsekvens på det institutionelle niveau af faktoren: integration mellem formel og uformel lcering. Denne integration forudsætter et nært samarbejde mellem arbejdspladsens ledelse og relevante uddannelsesinstitutioner der forestår voksen- og efteruddannelse. Indholdet af samarbejdet drejer sig om flere forhold:

- Et samarbejde om at afklare arbejdspladsens situation, karakteristika, uddannelsesbehov og problemer som grundlag og udgangspunkt for planlægning og udførelse af kompetenceudviklingsforløb. Uddannelsesinstitutionen kan i denne indledende fase være initiativ med henblik på at forestå relevante undersøgelser af arbejdspladsen.

- Et samarbejde om at afklare rammer, metoder og ressourcetilførsel til kompetenceudviklingsprojektet.

- Et samarbejde om de forhold, hvor der skabes en nær kobling mellem arbejdsplads og kursus, - jfr. ovenstående. Særlig vigtig er her ledelsens legitimering af at arbejdspladsforbedringer, der er planlagt under kurset, og viden og færdigheder, der er udviklet under kurset, kan overføres til arbejdspladsen. Tilsvarende skal ledelsen legitimere, at arbejdspladserfaringer og - problemer må tages op til behandling på kurset.

- Der skal være et samarbejde om follow-up på arbejdspladsen, af implementeringen af planer om forbedringer på arbejdspladsen.

\section{Ad 1.3 Arbejdspladsens øverste ledelse og daglige ledelse støtter og legitimerer kompetenceudviklingstiltagene på arbejdspladsen}

At hjælpe læring på vej er et ledelsesansvar, som det formuleres af Henrik Holt Larsen (Larsen, 2002, p. 10). Det er veldokumenteret at ledelsen er væsentlig og har et betydeligt ansvar for læring i arbejdet. Ledelsen har dels en væsentlig betydning på et overordnet niveau med at legitimere, støtte og tildele ressourcer og rammer til kompetenceudvikling. Hertil kommer at ledelsen har ansvar mht. at give støtte til en række mere konkrete funktioner i kompetenceudviklingen af medarbejdere på arbejdspladsen. I denne forbindelse kan der peges på at ledelsen skal facilitere samtlige de forhold der i denne konklusion fremhæves som væsentlige for læring i arbejdet. 


\section{Ad 1.4 Medarbejderinvolvering}

Medarbejderinvolvering (medarbejderinddragelse, medarbejderdeltagelse, participation) er en meget væsentlig succesfaktor. Medarbejderinvolvering er en del af læringskulturen på virksomheden: medarbejderne anses grundlæggende af ledelsen for at være ressourcer for virksomhedens produktion og udvikling. Medarbejderinvolvering er også en væsentlig motivationsfaktor: motivation for at indgå i videndeling og i kompetenceudviklingsforløb.

Både arbejdet med at mobilisere og artikulere medarbejdernes erfaringskundskab (uformel læring) og med at sammenkoble de forskellige perspektiver til en samlet helhedsopfattelse, kræver en høj grad af medarbejderinvolvering, fra de ansattes side. (Eikeland\&Berg, 1997). I fremstillingen ovenfor fremgår det, i hvor mange sammenhænge medarbejderinvolvering indgår, og hermed er en meget væsentlig succes-faktor.

Medarbejderinvolvering kan finde sted på mange niveauer og i mange funktioner, herunder bl.a.: i planlægning og tilrettelæggelse af efter- og videreuddannelse, i større omstillingsprocesser på arbejdspladsen, i forsøgs- og udviklingsarbejder, i produktionsgruppens arbejdsplanlægning og planlægning af læreprocesser, f.eks. i sidemandoplæring (ikke formel læring), medvirkning i virksomhedens udviklingsorganisation, mv.

\section{Ad 1.5 Efter- og videreuddannelsesforløb er karakteri- seret ved:}

a. Virksomhedstilpasset undervisning. Undervisningsforløbene er skræddersyet til arbejdspladsens situation og kompetenceudviklingsbehov.

b. Målorienteret uddannelse. Uddannelsen er orienteret mod at realisere tydeligt formulerede mål. Målene er relateret til arbejdspladsens udvikling.

c. Fleksibilitet. Undervisningsforløbene er fleksible, dvs. at undervisning og læring i sin realisering løbende indrettes efter behov og problemer der opstår hos medarbejderne og på arbejdspladsen. I mere individuelt designede uddannelsesforløb forbindes fleksibilitet med at læring tilpasses den enkelte medarbejders forudsætninger, tempo, erfaringer, læringsstil mv.

d. Erfaringsbaseret læering er udgangspunktet. I uddannelsesforløbene indgår et samspil mellem teoretisk viden og praksisviden/erfaringer, men medarbejdernes erfaringer og arbejdssituation er et væsentligt udgangspunkt og forbliver et centralt omdrejningspunkt for undervisningen. 
e. Teori-praksis kobling som et gennemgående element. Teori anvendes som optik og perspektiver på praksis, praksis generaliseres og forstås i lyset af teori.

f. Adgang til lceringsressourcer. Læringsressourcer kan være lærere, vejledere, mentorer - der både kan være tilstede i undervisningsforløbene og på arbejdspladsen - interaktivt studiemateriale, IKT/netbaseret læringsredskaber, osv.

g. Arbejdsformerne er dialogprcegede og problemorienterede, og giver deltagerne mulighed for at være aktive, handle, eksperimentere og forbinde teori og praksis, og forbinde kursussituation med arbejdssituationen.

h. Tidlig oplevelse af succes for medarbejderne. Uddannelsesforløbene tilstræber at etablere en tidlig oplevelse af succes hos deltagerne: deltagerne engagerer sig i læreprocesser, oplever at det lærte har relevans for arbejdssituationen og kan bruges, at det er meningsfuldt at lære og at læring kan overføres til arbejdspladsen og give indflydelse.

\section{Ad 1.6 Muligheder for refleksion. Etablering af reflek- sionsrum.}

Refleksion er en kompleks proces der forbinder tænkning, handling og erfaring. Man kan reflektere alene eller sammen med andre, om egne handlinger og erfaringer, eller fælles handlinger og erfaringer. Refleksion kan defineres som:

En intellektuel og evt. social aktivitet, hvor individer undersøger egne handlinger i bestemte sociale situationer, idet tidligere erfaringer tages op til undersøgelse og revurdering, med en analyse af årsager og virkninger af handlinger og hændelsesforløb i det sociale felt, med mulighed for at drage konklusioner om, og lave planer for fremtidige handlinger.

Refleksion indebærer et „stop og tænk“, at træde et skridt tilbage, og undersøge sammenhænge mellem handlinger og sociale processer, undersøge egne og fælles erfaringer. Refleksion indeholder både et tænken tilbage, og et tænken frem og handle fremadrettet for at løse problemer og få nye indsigter og erfaringer om forholdene på arbejdspladsen.

I megen læringsteori fremhæves refleksion som en grundlæggende faktor i læreprocesser, herunder praksislæring og læring på arbejdspladsen.

Nogle vigtige konkrete funktioner i kollektiv refleksion (refleksion som sociale processer) er:

- At lære af fejl

- Videndeling

- Fællesskab omkring mål og visioner (vision sharing) 
- Udfordring af vanemæssig og rutinepræget tænkning (Challenging groupthink)

- Feed-back processer. At bede om feed-back. Follow up på initiativer og udviklingsprojekter. (Høyrup, 2004)

Succesfuld arbejdspladslæring er karakteriseret ved at der er etableret gode muligheder for refleksion.

Undervisningsforløb kan fungere som en ramme om refleksion, og kan understøtte refleksion, og dette med mulighed for at støtte flere af elementerne i refleksion: se tilbage på erfaringer, sammenholde erfaringer og anlægge nye perspektiver på og kritisk vurdering af erfaringer, bl.a. i lyset af nye teoretiske perspektiver. Mulighederne for at tænke frem, og handle fremadrettet kan gennemføres på et eksperimenterende plan i undervisningssituationer eller kan implementeres i det virkelige liv, på arbejdspladsen. Refleksionsprocesserne kan således forbinde teori med praksis, formel læring med uformel læring, og individuelle processer med sociale processer på arbejdspladsen. Refleksiv lering på denne måde er grundlaggende for udvikling af kompetencer.

På arbejdspladsen kan refleksion foregå i forskellige rum: I forskellige former for møder, planlagte og institutionaliserede møder og spontant afholdte møder. Arbejdspladsen kan indrette små kontorer for refleksion der er placeret ude i produktionen, således at refleksionsaktiviteter og arbejdsaktiviteter er planlagte og integrerede i forhold til hinanden. Refleksion foregår typisk i forbindelse med planlægning af forsøgs- og udviklingsarbejder på arbejdspladsen, og follow up på udviklingstiltag, der er en væsentlig motor for at vedligeholde udviklingsprocesser og læreprocesser på arbejdspladsen, kan ses som et væsentligt element i refleksion.

Endelig kan refleksion forekomme som et fast etableret element i den lærende organisation.

\section{Ad 1.7 Integration af individuel læring og organisatorisk læring: integration af individuelle udviklingsprocesser og sociale forandringsprocesser på arbejdspladsen.}

Kompetence er mere end viden, kompetence er en betegnelse for viden, kunnen, færdigheder, holdninger mv. der kan bruges, dvs. omsættes i handling til løsning af arbejdsmæssige krav og udfordringer. Kompetencer udmøntes i handlinger i det sociale felt der udgøres af arbejdspladsen. Best practice er karakteriseret ved at arbejdspladsen i sin dagligdag understøtter og giver rum for udøvelsen af disse handlinger. Nogle konkrete eksempler herpå er:

- Når medarbejdere kommer tilbage til deres arbejde efter et kompetenceudviklingsforløb sluses de ikke straks ind i de 
arbejdssituationer og arbejdsrutiner de tidligere har haft. Der skabes en overgangsperiode, hvor medarbejderen kan eksperimentere og prøver sig frem med at udfolde sine nye kompetencer.

- Kompetenceudvikling følges op af ændringer i medarbejderens jobsituation, f.eks. således at arbejdsopgaverne bliver mere krævende, mere komplekse, mere ansvarsfulde eller indebærer en større handlefrihed (dispositionsrum). Større indflydelse på eget arbejde. Kompetenceudvikling forbindes med karriereudvikling. I denne sammenhæng kan kompetenceudviklingen også følges af højere løn, eller evt. mere generelt et lønsystem der er incitament for kompetenceudvikling.

- Efter- og videreuddannelsesforløb indeholder som et element udformning af planer om forbedringer i det daglige arbejde, og en implementering på arbejdspladsen af disse planer.

- Follow up og klare mål for virksomhedens udvikling. Follow-up i relation til implementering af planer om forbedringer udarbejdet på efteruddannelsesforløb, eller i relation til implementering af forsøgsog udviklingsprojekter på arbejdspladsen. Follow up er grundlæggende for en organisatorisk læring der består i, at medarbejdere og ledelse i fællesskab gør deres erfaringer op mht. hvad konsekvenserne har været for arbejdspladsen af implementeringen af forskellige udviklingstiltag. For at kunne opgøre konsekvenserne og vurdere dem, er det uomgængeligt at virksomheden har klare mål for sin udvikling, så eventuelle divergenser mellem en intenderet og en faktisk udvikling kan kortlægges. Dette kan igen danne baggrund for nye handlinger eller udviklingsarbejder der kan ses som led i organisatorisk læring.

\section{Ad 1.8 Efter- og videreuddannelse og kompetenceudvik- lingstiltag er led i en mere omfattende strategi for udvik- ling af virksomheden.}

Kompetenceudviklingstiltag må ikke være designet som lokale, afgrænsede og selvstændige projekter, afgrænset fra virksomheden som helhed. Best practice former for arbejdspladslæring er karakteriseret ved at være en integreret del af virksomhedens overordnede udviklingsstrategi og målrealisering, og være relateret til andre læringstiltag og udviklingsprojekter. 


\section{Ad 1.9 Arbejdspladsen støtter forandringer der hidrører fra kompetenceudvikling og integrerer kompetenceudvik- ling med rutiner inden for personaleudvikling.}

En af de væsentlige rutiner der her tænkes på er MUS: medarbejderudviklingssamtaler. I disse samtaler kan medarbejdernes uddannelsesbehov klarlægges, og anvendes som grundlag for arbejdspladslæringen. Tilsvarende kan MUS anvendes som grundlag for at erhvervede kompetencer relateres til karriereudvikling, nye jobs, forbedrede lønforhold mv. Arbejdspladsen kan formelt anerkende erhvervede kompetencer - herunder realkompetencer - gennem skriftlige anerkendelser, f.eks. i form af „kørekort“ til bestemte maskiner, arbejdsfunktioner o.lign.

\section{Ad 1.10 Helhedsperspektiv på virksomheden.}

De succesfulde strategier i læring i arbejdet støtter medarbejderne i at opnå et helhedsperspektiv på virksomheden. Helhedsperspektivet kan skabes på mange måder. Det kan skabes gennem den måde hvorpå deltagere udvælges og grupperes på i forbindelse med læringsaktiviteter (dannelse af grupper på tværs af formelle afdelinger, så erfaringsudveksling på tværs af grænser forekommer).

Helhedsperspektivet kan skabes gennem arbejdsorganiseringen på arbejdspladsen, der er en vigtig faktor i læringsmiljøet: f.eks. ved afgrænsningen af produktionsgruppers ansvarsområde, således at gruppen ikke kun har ansvar indadtil, men også ansvar udadtil - mod helheden - i relation til planlægningsafdelingen, kvalitetssikringsafdelingen, osv. Ved medarbejderinvolvering i virksomhedens forsøgs- og udviklingsprojekter, mv. Gennem refleksion, på møder, i undervisning og refleksion som en integreret del af arbejdsorganiseringen. Helhed kan skabes gennem refleksion. Eikeland\&Berg påpeger, at ingen - hverken ledelse eller medarbejdere - har direkte adgang til helheden.( Eikeland\&Berg, 1997).

Samtidig er et helhedsperspektiv fundamentalt: medarbejdere sidder ofte inde med kendskab til, hvorfor ting går galt, og med gode ideer til hvordan problemer kan løses. En vigtig grund til at kommunikation og samarbejde er vigtig i en organisation er netop hver enkelt medarbejder og leders begrænsede perspektiv, mangel på helhedsperspektiv. For at danne sig et billede af helheden er det nødvendigt at snakke sammen, forstå de andres perspektiv og forsøge at sætte perspektiverne sammen. ((Eikeland\&Berg, 1997). Dette kan bl.a. ske gennem refleksion. 


\section{Ad 1.11 Anvendelse af vejledere og mentorer på arbejds- pladsen.}

Dette er også en måde hvorpå arbejdspladsen støtter medarbejdernes kompetenceudvikling. Der findes mange måder at beskrive vejlederes og mentorers opgaver og funktioner på. Her kan kort nævnes at vejlederen har faglig ekspertise inden for det fagfelt, hvor kompetenceudviklingen finder sted, og således direkte kan give faglig støtte og være en læringsressource for medarbejderen. Mentoren er en person der hjælper medarbejderen med at holde styr på og koordinere de mange forskellige læringssammenhænge og læringsmuligheder og læringsressourcer der står til rådighed for medarbejderen. Både vejleder og mentor tager udgangspunkt i medarbejderens perspektiv i forhold til uddannelse.

\section{Ad 1.12 Etablering af særlige roller på arbejdspladsen til støtte for læring i arbejdet.}

Der kan være tale om en Human Ressource leder, tillidsrepræsentant mv., der løbende er forpligtet til at tage spørgsmål om medarbejderudvikling op på relevante møder, og løbende tage initiativ til igangsætning af udviklingsprojekter og især varetager spørgsmålet om follow - up på uddannelsesaktiviteter og udviklingsarbejder på arbejdspladsen. Forekomsten af „ildsjæle“ på arbejdspladsen er en uformel men vigtig rolle der kan forekomme sammen med institutionaliseringen af særlige roller, hvor personalechefer eller tillidsrepræsentanter kan holde ideer (fra efter - og videreuddannelsesforløb, udviklingsarbejder mv.) levende, bringe dem videre i systemet og tage vare på at de bliver implementeret i arbejdshverdagen.

\section{Ad 1.13 Arbejdspladsen er indrettet som et optimalt læ- ringsmiljø for læring i arbejdet.}

Dette er arbejdspladslæring i snæver forstand, på dansk anvendes undertiden udtrykket „lcering på jobbet“ (Henrik Holt Larsen, 2002). Der er her tale om den interaktive strategi, hvor kompetence udvikles og anvendes parallelt. Selv om der her ikke er tale om efter - og videreuddannelse af voksne i form af kurser mv., er det erfaringen fra projektet, at selv når arbejdspladsen har udviklet et i høj grad optimalt læringsmiljø og en udviklet struktur og kultur for videndeling, har arbejdspladsen ofte et yderligere behov for viden tilført udefra, fra uddannelser.

Overordnet kan man med Henrik Holt Larsen (2002, p. 12) sige at denne model for læring understreger de læringsmuligheder der ligger 
indbygget i det enkelte job, i samspillet mellem mennesker og job, og i samspillet mellem det enkelte menneske og organisationen.

Følgende faktorer karakteriserer et godt læeringsmiljø i arbejdet:

1.13.1 Arbejdsopgaverne. Arbejdsopgaverne er indrettet så de støtter læring ved:

- at der findes variation i arbejdet hvad angår: hvad man gør, hvordan, med hvem, hvor og hvornår

- at arbejdsopgaverne har et udfordrende indhold i forhold til medarbejderens forud-sætninger

- at medarbejderne får feed-back på udført arbejde

- at der findes autonomi (frihedsgrader) i tolkningen og udførelsen af arbejdet

- at arbejdsopgaver delegeres

- at der er mulighed for medarbejderne til at udvikle et helhedsperspektiv

- at det er muligt af lære af fejl

1.13.2 Støtte for laring i det daglige arbejde, f.eks. gennem:

- møder med erfaringsudveksling og refleksion

- vejledning, kollegial supervision, brug af mentor mv.

- udviklingsprojekter

- efterspørgselstyret uddannelsestiltag

1.13.3 En arbejdsplads leringskultur er karakteriseret ved:

- åbenhed og tillid, snarere end angst og usikkerhed

- initiativ og risk-taking understøttes

- tolerance over for forskelligheder, usikkerhed og fejl

- opmuntring til at tænke alternativt og afprøvning af indarbejdede tænkemåder og arbejdsmåder

1.13.4 Virksomheden er organiseret for både produktion og laring (udvikling), hvilket bl.a. kræver at tilstrækkelig tid og ressourcer afsættes til lærings- og udviklingsaktiviteter. Der er eksempler på virksomheder der fast ansætter et større antal medarbejdere end det der direkte fordres af produktionen, fordi en vis del af arbejdskraften løbende er engageret i efter- og videreuddannelse. Der er mulighed for at en virksomhed der i sin formelle organisationsstruktur har en afdeling med ansvar for opfølgning på uddannelsestiltag, eller ansvar for udviklingstiltag. Væsentlig er de i organisationen indbyggede muligheder for refleksion og videndeling. 
1.13.5 Ledelsens betydning, ledelseskompetence: at ledelse på alle niveauer på arbejdspladsen forstår betydningen af og har kompetence til at organisere for og støtte lærings- og udviklingsprocesser.

Som nogle konkrete eksempler kan nævnes, at kravene til arbejdsopgaverne f.eks. kan realiseres gennem en arbejdsorganisering med produktionsgrupper. Gennem en team-organisering kan sikres variation, udfordring, autonomi (selvstændighed), feed-back og mulighed for at lære af fejl. Medarbejderinddragelse i virksomhedens udviklingsprojekter fremmer variation, udfordring, autonomi og udvikling af læringskulturen, og mulighed for at give medarbejderen et helhedsperspektiv på virksomheden.

Variation og udfordring understøttes også typisk af job-rotation i arbejdet.

\subsection{Konkrete modeller for best practice}

Følgende fem modeller realiserer en betydelig andel af de bærende succes-faktorer:

Model 1:

Etablering af en udviklingsorganisation uden for arbejdspladsen, og samtidig i samspil med arbejdspladsen.

Best practice: Undervisning som arbejdsplads intervention.

Model 2:

Erhvervsbaseret læring (Yrkesbaserat Lärande). Etablering af samarbejde mellem en uddannelsesinstitution og en arbejdsplads, hvor arbejdspladsens praksis er udgangspunkt for integration af praksisviden og teoretisk viden. Söderhamn modellen.

\section{Model 3:}

Medarbejderuddannelse gennem gap-analyse baseret på medarbejderdia$\log$.

Model 4:

E-læring og fleksibel læring på arbejdspladsen. ${ }^{2}$ Etablering af minilæringscentre på arbejdspladsen.

\footnotetext{
${ }^{2}$ Begrebet E-læring dækker over læring med og gennem informations- og kommunikationsteknologi (IKT). I bred betydning korresponderer det med det internationale begreb CSCL: Computer Supported Collaborative Learning
} 
Model 5:

Arbejdspladsen som ramme og læringsmiljø for medarbejdernes kompetenceudvikling. Udvikling af et læringssystem på arbejdspladsen.

Model 5a:

Læringsmulighederne er integreret i arbejdspladsens organisation.

Model $5 b$

Arbejdspladsen er organiseret som en parallel organisation: en arbejdsorganisation i samspil med en udviklingsorganisation. Udviklingsorganisationen er et læringssystem på arbejdspladsen.

\subsection{Effekter der er kædet sammen med best practice}

Følgende er karakteristisk for effekterne:

1. Læringsprodukterne viser sig som forbedrede kompetencer til at udføre de konkrete arbejdsopgaver (job performance). Udvikling af specifikke faglige kompetencer.

2. Der kan skelnes mellem ,at gøre“- kompetencer og „innovative kompetencer" i form af selvstændighed i handling og problemløsning, evne til at finde nye løsninger på problemer, osv. Læringsprodukterne viser sig ikke blot som „at gøre“ (at udføre) kompetencer, men også som udvikling af de innovative kompetencer.

3. Der kan skelnes mellem snævre arbejdspladsrelaterede kompetencer og mere brede kompetencer i form af en generel højere værdi for medarbejderen. Læringsprodukterne viser sig som begge former for kompetencer, dvs. udvikling af en øget „employment“. Som eksempler på brede kompetencer der ofte ses udviklet kan nævnes:

- $\quad$ ønske om at præge arbejdspladsen

- ny tillid til at kunne øve indflydelse på arbejdspladsen, færdighed $i$ at formulere forbedringsforslag til arbejds"pladsen

- ændret holdning til uddannelse, øget interesse for at lære

- medarbejderne ser læring som en del af arbejdet

- $\quad$ viden om større dele af arbejdspladsen, arbejdspladsen som helhed

- udvikling af sociale kompetencer, f.eks. kompetencer der er nødvendige for at arbejde i teams

- $\quad$ kompetencer der drejer sig om at kunne se helheden og tage ansvar for helheden (arbejdspladsen)

- $\quad$ kompetencer vedr. initiativ og selvledelse, der er vigtige i en team-organiseret arbejdsplads. 
- Udvikling af „empowerment“ hos medarbejderne. Begrebet defineret som: „En larings - og utviklingsprocess som øker folks (individ, gruppe, samfunn) kontrol over faktorer som oppfattes betydningsfulle for egen helse og livskvalitet" (LHA I: Eikeland 2006).

4. Læringskompetencerne viser sig ikke alene på et individuelt niveau, men også som udviklinger på et organisationsniveau, som f.eks.: større effektivitet, udvikling af en læringskultur på arbejdspladsen, udvikling af en diskuterende og dialogpræget måde at samarbejde på, mv. Som eksempler kan nævnes:

- udvikling af en åbenhedskultur, hvor medarbejderne er åbne for nye udviklinger i virksomheden, og for at indgå i og engagere sig i disse udviklinger

- virksomheden, og for at indgå i og engagere sig i disse udviklinger

- Udvikling i virksomhedens samlede produktion og økonomi

- En integration af arbejde og lærings- og udviklingsprocesser

- En diskuterende og dialogpræget arbejdsmåde

- Virksomhedens målsætning bliver klarere for alle, og den enkelte medarbejder kan se hvordan han/hun kan bidrage til at realisere målsætningen

- Udvikling af et læringssystem på arbejdspladsen

- Optimering af arbejdspladsen som arena for læring.

\subsection{Anbefalinger:}

- At der udvikles et nærmere samarbejde mellem voksenuddannelsesinstitutioner og arbejdspladser, der ønsker kompetenceudvikling af medarbejderne.

- Samarbejdet omkring kompetenceudvikling af arbejdspladsen kan tage mange former: Der kan være tale om et fast engagement hvor voksenuddannelsesinstitutionen udgør et løbende støttesystem til Elæring og „blended learning“ (en kombination af computerstøttet læring og socialt baseret læringsaktiviteter), der forløber på arbejdspladsen. Der kan være tale om engangsforløb i form af undervisning med interventionssigte, hvor undervisning og organisationsudvikling integreres. Der kan være tale om konsulentbistand til arbejdspladsen for at støtte en udvikling mod et optimalt læringsmiljø i arbejdet. Der er mulighed for lederuddannelse, for at udvikle ledernes kompetencer til at initiere og styre kompetenceudvikling af medarbejderne.

- At voksenuddannelsesinstitutionerne får forbedret deres muligheder for at samarbejde med arbejdspladserne om undervisnings- og læringsforløb der er fleksible og tilpassede til arbejdspladsens situation. 
Dette indebærer at der skal gives voksenuddannelsesinstitutionerne vilkår til og en incitamentsstruktur til at arbejde med de fleksible og arbejdspladstilpassede læringsforløb, og at institutionernes organisation udvikles med henblik på at være effektiv til at varetage de nye opgaver.

- At medarbejderne på voksenuddannelsesinstitutionerne selv indgår i kompetenceudviklingsforløb, der giver dem kompetencer til at arbejde i nær tilknytning til og på arbejdspladserne med kompetenceudvikling for arbejdspladsens medarbejdere.

- At voksenuddannelsesinstitutionerne udvikler kompetence til og forestår lederudviklingskurser, der sigter mod at udvikle pædagogiske kompetencer hos arbejdspladsernes ledere og uddannelsesansvarlige, herunder kompetencer til at udvikle arbejdspladsens organisation til et optimalt læringsmiljø.

- At arbejdspladsernes ledere og uddannelsesansvarlige orienterer sig stærkere mod kompetenceudvikling af medarbejderne, bl.a. ved at indgå i netværk med arbejdspladser med udbyggede erfaringer herom, og med uddannelsesudbydere.

- Der er tegn på at voksenuddannelsesinstitutionerne har vanskeligt ved at „levere varen“ i form af den nyeste teknologiske viden, som virksomhederne har behov for. Det anbefales at voksenuddannelsesinstitutionerne intensiverer deres samarbejde med universiteterne (forskningstilknytning) inden for det teknologiske område, og endvidere tilsvarende samarbejde inden for det pædagogiske område med universiteter, der forestår uddannelsesforskning. Øget samarbejde og videndeling og videngenerering mellem forskningsinstitutioner, uddannelsesinstitutioner og arbejdspladser synes at være perspektivrigt.

\section{Referencer}

Eikeland Olav og Anne Marie Berg (1997): Medvirkningsbasert organisasjonslæring og utviklingsarbeid i kommunene. Oslo. Kommuneforlaget. Eikeland Olav, Liv Hanson Ausland m.fl. (2006): Har systematisk læring på arbeidsplassen noe med livsfaseog seniorpolitikk å gjøre? Rapportering fra Forsøks- og Utviklingsprosjektene i Nasjonalt Krafttak for seniorpolitikk i arbeidslivet (2001-2005).

Finansministeriet: Livslang opkvalificering og uddannelse for alle på abejdsmarkedet - rapport fra Trepartsudval- get - Bind 1: Den fremtidige voksenog efteruddannelsesindsats. Udgivet 07.02.2006

Holt Larsen, H. med flere (2002). Læring på jobbet. Et Overblick. KL og KTO.

Andersen, V., Clematide, B. og Høyrup,S.: Arbejdspladsen som læringsmiljø. Learning Lab Denmark, Roskilde Universitetsforlag, 2004. Heri især:

Steen Høyrup: Læringsformer, refleksionsprocesser og læringsrum i arbejdslivet, p. 73-98. 


\section{Læring i arbejdet - perspekti- ver og udgangspunkter}

Som baggrund for præsentationen af det nordiske projekt præsenteres i det følgende en bredere uddannelsespolitisk sammenhæng, som projektet kan ses i. Samtidig præciseres væsentlige begreber der anvendes i projektet.

\subsection{Et uddannelsespolitisk perspektiv: Lifelong learning og kompetence begrebet i UNESCO, OECD og EU}

Alt afhængig af, om inspirationskilden har været UNESCO’s begreb om lifelong learning eller OECE's begreb om recurrent education, har den politiske opmærksomhed i løbet af 1990'erne i stigende grad - og med forskellig betoning - været rettet mod voksnes uddannelse og læring, både internationalt og i Norden. Begreberne om livslang læring og tilbagevendende uddannelse afspejler, at de to organisationer historisk set har stået for forskellige teoretiske og ideologiske positioner. UNESCO har været relateret til kampen mod analfabetisme og en humanistisk tradition, hvor demokrati og personlig udvikling har væeret nøgleordene i begrebet livslang lering. OECD har som en organisation for økonomisk samarbejde og udvikling været orienteret mod arbejdsmarkedet og økonomisk vækst, og man har lagt vægt på tilbagevendende uddannelse som en vekselvirkning mellem arbejde og uddannelse gennem hele livet. De to tænkemåder og generationer har dog nærmet sig hinanden gennem årene og begge steder anvendes i dag begrebet livslang læring. De to positioner ligger stadig bag tænkningen i livslang læring: en humanistisk tradition, der betoner individets udvikling, lighed og sikring af uddannelse til alle, og en position hvor uddannelse ses som investering i „human capital“ iden globale økonomiske konkurrence. Her er man orienteret mod behovet for den nødvendige kvalificerede arbejdskraft med de rette faglige og personlige kvalifikationer/kompetencer.

Med vedtagelsen af Maastrichttraktaten i 1993 får EU en mere direkte betydning for det uddannelsespolitiske område. Med Memorandum om livslang læring (Kommissionen 2000) og ikke mindst med opfølgningen på memorandummet, Realisering af et europæisk område for livslang læirng (Kommissionen, 2001) står begreberne om livslang læring og kompetenceudvikling centralt. Væsentligt i denne tredje generation inden for lifelong learning er en udvidelse af det livslange læringssbegeb, til at inkludere lifewide learning. Lifewide learning er et udtryk for at vores tænkning om læring indebærer, at læring så at sige slipper ud af uddan- 
nelsesinstitutionerne. Læring finder stadig sted i disse institutioner, de er indrettet til det og det er deres formål, men læring finder også sted i to andre sektorer i samfundet: på arbejdspladserne og i den civile sektor. Tænkningen er, at kompetencer kan tilegnes i en hvilken som helst af de tre sektorer, og kan anvendes i alle tre sektorer. Hermed er arbejdspladsen som lceringsarena blevet fremhævet og knæsat begrebesmæssigt.

\subsection{Definitioner af grundlæggende begreber og afgræns- ning af feltet}

I Realisering af et europæisk område for livslang læring (Kommissionen, 2001) formuleres fire mål for livslang læring:

- Selvrealisering

- Aktivt borgerskab

- Social inddragelse

- Beskæftigelsesegnethed (employability)/tilpasningsevne.

Livslang læring defineres som:

Al læringsaktivitet, som man deltager i gennem hele livet, med det formål at fremme viden,

færdigheder og kompetencer set i et personligt, borgermæssigt, socialt og/eller beskæftigelsesrelateret mål.

Med denne brede definition fokuseres der på såvel formelle, ikkeformelle som uformelle læringsaktiviteter, både horisontalt og vertikalt i forhold til et livsforløb - altså læringssituationer og læringsaktiviteter forstået bredt og gennem hele livet.

I definitionen på livslang læring indgår begrebet „kompetencer“. I dokumentets ordliste defineres kompetence således:

Evnen til effektivt at anvende erfaring, viden og kvalifikationer.

Om kompetencebegrebet skal i denne sammenhæng kort siges følgende: Der hersker stadig blandt både forskere og uddannelsespolitikere uenighed eller manglende afklaring om begrebets brug og betydning, ikke mindst mht. hvad der er forskelle og ligheder mellem kompetencer og kvalifikationer. I store træk ser det ud til at kvalifikationsbegrebet var populært i Norden i 70'erne og 80'erne, medens kompetencebegrebet blev populært i 90'erne og stadig er det i dag. Kvalifikationsbegrebet var knyttet til industrisamfundet, kompetencebegrebet er knyttet til videnssamfundet. Hermed er kompetencebegrebet også knyttet til forskellige vidensformer - ikke blot „sikker viden“ og selvstændiggjort viden, viden 
der er kodificeret som sprog, men også kropsbunden viden, viden som intuition og såkaldt tavs viden - og til den opfattelse, at viden kan være noget meget omskifteligt. Endvidere er viden ikke blot „noget der er inde i hovedet på folk“, viden ligger også i relationer mellem medarbejderne, viden kan være spredt („distributed knowledge“) og viden kan deles, og videndeling kan ledes (Knowledge management).

I kompetencebegrebet synes der at være enighed om følgende grundlæggende træk:

- Kompetence er mere end viden. Det indeholder en række flere elementer, som f.eks. kunnen, færdigheder, holdninger, værdier, identitet mv.

- Kompetencer indeholder et element af handling og anvendelse. Der er tale om viden - og flere elementer - der kan omsættes i handling, viden der kan anvendes til løsning af foreliggende krav og udfordringer.

- Kompetencer kan udvikles både i formelle uddannelsessammenhænge, på arbejdspladsen og i den civile sektor. Kompetencer dækker således over et bredt læringsbegreb der inkluderer formel læring, ikke formel læring (f.eks. sidemandsoplæring) og uformel læring (læring der typisk er et sideprodukt til en anden aktivitet, f.eks. leg og arbejde).

De tre hovedtræk der går igennem kompetence og læringsbegrebet i den foreliggende rapport er således:

1. Kompetenceudvikling indebærer at det der er lært kan omsættes i handling, og kan anvendes til at løse opgaver, problemer og udfordringer

2. Kompetenceudvikling kan finde sted i flere forskellige læringsarenaer, herunder især formelle uddannelsesinstitutioner og arbejdspladsen

3. Kompetenceudvikling inkluderer både formel læring, ikke formel læring og uformel læring

\section{Afgrcensning og præcisering af feltet: voksnes læring i arbejdet}

Internationalt findes en række betegnelser der er næsten identiske mht. betydning, men som dog varierer lidt mht. at definere området relativt snævert resp. bredt: working life learning, workplace learning, work related learning, m.fl. På dansk taler vi om læring i arbejdet, arbejdslivslæring, arbejdspladslæring, etc.

I den foreliggende rapport har vi valgt en bred opfattelse af feltet, som vi benævner arbejdspladslæring. 
Vi inkluderer følgende aktiviteter og processer - læreprocesser - i området:

- Arbejdspladsen opfattet som et læringsmiljø, som en arena for læring. Dette perspektiv inkluderer to felter:

- Lærerprocesser der rent faktisk finder sted på arbejdspladsen, og dette gælder både læring der er planlagt og formaliseret, som f.eks. sidemandsoplæring og jobrotation, og læring der finder sted som et sideprodukt til arbejdsprocessen, selv om der er tale om en læring som ledelse resp. medarbejdere ikke selv er sig bevidst (informal learning, incidental learning).

- Bestræbelser på at udforme dette læringsmiljø så det bliver hensigtsmæssigt og effektivt, f.eks. gennem udformning af arbejdsopgaverne så de bliver varierede og rimeligt krævende, udformningen af arbejdsorganiseringen i f.eks. produktionsgrupper, der indeholder muligheder for team-læring med høj indflydelse og ansvar.

- Undervisningsaktiviteter - der kan finde sted på arbejdspladsen (arbejdspladsforlagt undervisning) eller uden for arbejdspladsen, på f.eks. et uddannelsescenter - hvor der tilstræbes en nær integration mellem undervisningen og forholdene på en konkret arbejdsplads. Integrationen kan f.eks. dreje sig om undervisningens indhold, der i høj grad bliver forhold, problemer og udviklingsplaner på arbejdspladsen, eller om undervisningens mål, hvor målet ikke blot er at den enkelte deltager lærer, men også at det den enkelte lærer skal anvendes på arbejdspladsen, til at forbedre praksis, til at støtte forandringsprocesser og organisatoriske forhold på arbejdspladsen. Vi kan her tale om undervisning som intervention på arbejdspladsen.

Vores definition af begrebet arbejdspladslæring - workplace learning ligger således tæt op ad den begrebsbestemmelse der anbefales af $\mathrm{K}$. Evans:

Workplace learning as learning in, for, and through the workplace. K. Evans: (2006, p. 19)

Målet for arbejdspladslcring vil almindeligvis være dobbelt og på to niveauer: et mål er kompetenceudvikling af den enkelte medarbejder. Et andet mål er forandring og forbedring på organisationsniveau, dvs. udvikling af arbejdspladsen. Førstnævnte mål kan være et middel til at realisere det andet mål, arbejdspladsudvikling. Arbejdspladsudvikling i form af udvikling af arbejdspladsen som læringsmiljø kan være et middel til kompetenceudvikling af medarbejderne der igen tilsigter at virke positivt ind på arbejdspladsens produktion. Kompetenceudviklingen kan dreje sig om kompetencer til at udføre arbejdet på den konkrete arbejdsplads, men 
der er også mulighed for at de udviklede kompetencer er mere brede, så de indebærer en udvikling af medarbejdernes employability (generelle arbejdsegnethed på arbejdsmarkedet).

\section{Referencer}

Evans, K. et al (2006) Improving Workplace Learning. Routledge. London.

Korsgaard, O. (1999) Kundskabskapløbet - uddannelse i videnssamfundet. Haslev: Nordisk Forlag, Gyldendal.

Kommisionen for de europæiske fællesskaber (2000). Memorandum om livslang læring. Europa-kommissionen, Arbejdsdokument fra EUkommissionens tjenestegrene. Bruxelles, 30/10-2000
Kommisionen for de europæiske fællesskaber (20010). Realisering af europæisk område for livslang læring. Eurpopa-kommissionen, Generaldirektoratet for Udannelse og Kultur og Generaldirektoratet for beskæftigelse, sociale anliggender og Arbejdsmarkedsforhold. Bruxelles.

Steen Høyrup og Kim Pedersen: Kampen om kompetencerne. Kapitel i: Bryderup, I.M. (red) Pædagogisk Sociologi. En antologi. Danmarks Pædagogiske Universitets forlag 2003, p. 187-211. 



\section{Det nordiske projekt: Voksnes læring i arbejdslivet}

\section{Projektets mål}

Projektets mål er at kortlægge former for best practice mht. læring i arbejdet. Målet er at afdække: „What works in workplace learning“. Ud over det faglige indhold indgår en løbende formidling om projektet, som en del af projektets mål.

Forskerne søger at beskrive og analysere forskellige former for praksis mht. læring i arbejdet, der virker og har den tilsigtede effekt. På baggrund af case-studier, søger forskerne dels at udlede modeller for, hvordan læringsforløb og kompetenceudvikling kan organiseres på hensigtsmæssige måder, og søger at identificere faktorer der har en grundlæggende betydning for at læring og kompetenceudvikling finder sted på effektiv måde på den enkelte arbejdsplads.

\section{Opdraget}

Undersøgelsen har karakter af et udredningsarbejde, en vidensopsamling om voksnes læring i arbejdslivet. Der skal ikke igangsættes ny empirisk forskning på feltet.

Det ligger i opdraget, at projektet skal gennemføres i de nordiske lande: Norge, Sverige, Finland, Danmark og Island, og selvstyreområderne Grønland, Færøerne og Ålandsøerne, - dette under forudsætning af at der foreligger et egnet materiale (case-beskrivelser) i forhold til de opstillede kriterier.

Under projektets gennemførelse viste det sig at det kun var muligt at indhente case materiale der imødekom kriterierne i Norge, Sverige, Finland, Danmark, hvorfor kun disse lande indgår i projektet.

\section{Tidsramme}

Projektet starter i november 2005 og afsluttes ultimo 2006, med en midtvejsstatus omkring maj måned. Projektets afslutning er senere udsat til primo februar 2007. 


\section{Metode}

Med henblik på at realisere projektets mål er der anvendt en kombination af to metoder. Der er gennemført en „state of the art“ hvor den eksisterende og aktuelle viden inden for feltet er kortlagt. Denne viden der bygger på et bredt spektrum af empiriske studier kombineres med viden der skabes af et lille antal intensive studier - case studies - der overvejende er gennemført på mindre antal arbejdspladser. Case studierne skal sikre, at vi i forskningen er tæt på praksis.

Det er en kombination af disse to tilgange - den ekstensive og den intensive - der ligger til grund for rapportens konklusioner. Gennem denne kombination af ekstensive og intensive studier udnytter vi både fordelen ved intensiv forskning tæt på praksis, der bygger på kvalitative data, og samtidig sikrer vi gyldigheden af vores forskningsresultater i kombinationen med den ekstensive metode, således at gyldigheden af vores forskningsresultater går ud over de enkelte undersøgte arbejdspladser.

\section{Kriterier til udvælgelse af casene}

Der er på forhånd opstillet en række kriterier, som de udvalgte cases om læring i arbejdet skal opfylde:

- Der er særlig fokus på kortuddannede: hvordan sikres de kortuddannede de optimale læringsmuligheder

- Realkompetenceafklaring af medarbejderne må gerne indgå som grundlag for læringen i arbejdet

- Casen skal så vidt muligt indeholde et samspil mellem uddannelsesinstitutioner og kompetenceansvarlige på arbejdspladsen

- Casen skal kunne siges at være et eksempel på „best practice“, der også indeholder en rammebeskrivelse (organisation, økonomi mv.) for den beskrevne praksis

- Casen skal være tæt på praksis

- Det er en fordel hvis teori-praksis problematikken bliver behandlet direkte i casen

Hovedreglen har været, at der skal udvælges én case fra hvert af de nordiske lande. Nævnte krav til casene har dog vist sig at være så krævende, at det - som nævnt ovenfor - kun har været muligt for forskerne at finde cases, der nogenlunde imødekommer kriterierne, i Sverige, Norge, Danmark og Finland. Den foreliggende rapport bygger på to cases fra Sverige, én fra Norge, to fra Sverige og én fra Finland.

Det at sammenligne „det gode eksempel“ fra de respektive nordiske lande regner vi for at være et frugtbart og konstruktivt grundlag for at 
afdække faktorer af særlig stor betydning for at læringen er effektiv og hensigtsmæssig.

Idet der er tale om „det gode eksempel“ eller „best practice“ har det ved udvælgelsen af casene været vigtigt, at der eksisterer en god dokumentation for at der er opnået gode resultater gennem den pågældende praksis, den anvendte metode. Der bygges her på data fra virksomhedsledere og forskere.

\section{Forskningsspørgsmål}

Gennem den tematiske og tværgående analyse af casene søges følgende spørgsmål belyst:

- Hvad karakteriserer den pædagogiske strategi, den anvendte metode i casen?

- Hvilken kompetenceudvikling er det der sker? Hvilke typer af kompetencer udvikles?

- Hvad karakteriserer forholdet mellem teori og praksis i læringen?

- Er der tale om individuel eller organisatorisk læring, dvs. spørgsmålet om læring som individuelle- eller sociale forandringer i arbejdet.

- Ledelsens betydning for etableringen og gennemførelsen af kompetenceudviklingsforløb på arbejdspladsen.

\section{Gennemførelsen af projektet. Hovedfaserne i projektet har været:}

Planlægning af projektet, der er forløbet ultimo 2005 og primo 2006. Herefter er der taget kontakt til forskningsmiljøer og foretaget indsamling og udvælgelse af cases. Efterfølgende har arbejdet drejet sig om bearbejdning, udbygning, supplering af case beskrivelser, beskrivelser af cases: besøg/møder, interview mv. Arbejdet afsluttes med bearbejdning og analyse af cases.

Lidt mere detaljeret kan projektgennemførelsen beskrives således:

Til og med juni 2006 drejer arbejdet sig i det væsentligste om:

- At opsøge forskningspublikationer, rapporter o.lign., gennem kommunikation med forskere og forskningsmiljøer i de resp. nordiske lande.

- At gennemlæse og analysere det indsamlede forskningsmateriale i relation til kriterierne.

- At udvælge én (evt. to) case(s) fra hver af de nordiske lande, - ud fra de formulerede kriterier. 
- Hertil kommer indsamling af yderligere informationer til supplering af casematerialet (f.eks. ved interview af forfatteren) og evt. omskrivning, bearbejdning eller supplering af den foreliggende caseredegørelse/forskningspublikation.

Primo 2007 er anvendt til skrivning af rapporten med konklusioner og anbefalinger.

En erfaring fra dette arbejde var, at det var meget vanskeligt at finde case beskrivelser, der blot imødekommer de væsentligste af kriterier der var opstillet. Det har derfor været nødvendigt for os at udvælge case - og forskningsbeskrivelser der var mangelfulde i forhold til vores kriterier og efterfølgende arbejde med at supplere og uddybe casebeskrivelserne. Dette er gjort ved at kontakte forskerne bag casebeskrivelserne og lærere og praktikerne på arbejdspladserne, for at indsamle datamateriale til at supplere casebeskrivelserne.

Den efterfølgende bearbejdelse af casematerialet er foregået sådan, at de meget omfattende casebeskrivelser - vores rådata - er forkortet ned til korte casebeskrivelser. Beskrivelserne er ikke blot kortet ned, de er også sat på en systematisk form - den samme skabelon. Sidstnævnte har gjort det muligt at læse på tværs af casene, og gennemføre tematiske analyser, f.eks. for at sammenligne den anvendte strategi, opnåede resultater osv.

Casene dækker følgende områder: fremstillingsvirksomhed (den ene danske og den finske case), procesindustri (den ene danske case), human service og sundhedsområdet (den norske case). De to svenske cases har en mere generel karakter, idet modellerne er anvendt på flere arbejdspladser. 


\section{Vad vet vi? En översikt av tidigare nordisk forskning om kompetens-utveckling i arbets- livet}

I det följande kapitlet ges en översikt om kompetensutveckling i företag och organisationer utifrån tidigare forskning. Vi har därvid avgränsat oss till i första hand forskning kring kompetensutveckling i de nordiska länderna. Vad vet vi då utifrån tidigare forskning om utbildning och andra former för kompetensutveckling i företag? Varför görs satsningar på kompetensutveckling? Vilka motiv och syften kan urskiljas? Hur går man i företagen konkret tillväga, vilka metoder och angreppssätt används? Hur kan vi förstå vilka specifika mekanismer och förhållanden som har betydelse för att nå framgång med satsningar på kompetensutveckling på arbetsplatsen? Vilka effekter uppnås för organisationen och för deltagande individer?

Trots de förväntningar som finns vad gäller satsningar på kompetensutveckling, och trots de stora satsningar som trots allt görs i de nordiska länderna, så kan man konstatera att vi fortfarande i hög grad saknar empiriskt baserad, pedagogisk forskning om kompetensutveckling och vuxnas lärande i arbetslivet. Vi har endast lyckats identifiera ett fåtal studier där man undersökt satsningar på kompetensutveckling i arbetslivet med fokus på de frågeställningar som intresserar oss i denna rapport. Den empiriska forskning som finns kring dessa frågor utgörs istället i stor utsträckning av ekonomisk forskning. Även om man inom detta område gett en rad viktiga bidrag för förståelsen av kompetens- och utbildningsfrågor och deras betydelse för företaget, så betraktas utbildnings- och lärandeprocesser i organisationer i denna forskning ofta utifrån ett "black box" perspektiv, dvs. som givna storheter som inte närmare problematiseras och studeras.

I den forskningsöversikt som ges i detta kapitel kommer vi att fokusera på följande tre frågeställningar:

- Varför satsar verksamheter på att arrangera olika former för kompetensutveckling för de anställda?

- Vilka effekter är realistiska att uppnå genom satsningar på kompetensutveckling?

- Vad kännetecknar framgångsrika strategier och metoder för kompetensutveckling i organisationer? 
Innan vi går in på dessa frågor är det dock på sin plats att säga något om begreppet kompetensutveckling som det kommer att användas i det följande.

\subsection{Hur bedrivs kompetensutveckling i arbetslivet?}

Vi kan här definiera kompetensutveckling som en sammanfattande beteckning för de olika åtgärder som kan utnyttjas för att påverka utbudet av kompetens på en verksamhets interna arbetsmarknad (hos enskilda anställda; grupper av anställda eller hela personalgruppen). Allmänt sett, så kan avses åtgärder som innebär:

- Planerad utbildning eller träning av personal genom t ex kurser på eller utanför arbetsplatsen, och som leder till betyg eller någon form av certifierning (s k formell utbildning).

- Olika typer av planerade satsningar på lärande på en arbetsplats som dock inte är avsedda att leda till betyg eller certifiering, till exempel seminarier, handledning, nätverk (icke-formellt lärande).

- Lärande i och genom det dagliga arbetet som inte är planerat eller kanske ens medvetet (informellt lärande). Detta lärande kan främjas eller motverkas exempelvis beroende på hur arbetsorganisationen utformats eller beroende på hur ledarskapet utövas i verksamheten.

Kompetensutveckling på arbetsplatsen kan alltså utgöra en eller flera av dessa åtgärder eller ingå i ett "system” av åtgärder. Det bör i sammanhanget påpekas att termen kompetensutveckling ibland även används i en annan betydelse, nämligen som beteckning på de individuella lärprocesser som leder till en förändring av individens kompetens. Vi kan alltså skilja mellan en organisationsrelaterad och en individrelaterad innebörd av termen kompetensutveckling. Här är det också viktigt att understryka att även aktiviteter som inte har kompetensutveckling eller lärande som primärt syfte, i realiteten kan innebära kompetensutveckling för individen. Det är detta som ovan avses med informellt lärande. Exempel på detta är deltagande i olika typer av utvecklingsprojekt eller satsningar på arbetsrotation, liksom naturligtvis t ex facklig eller politisk verksamhet.

I en nyligen avslutad utvärdering av kompetensutveckling i små- och medelstora företag som ingått i det svenska Mål 3 programmet (Svenska ESF-Rådet, 2003) kunde man med hjälp av statistiska analyser av svaren på en enkät ställd till ett stort antal arbetsplatser $(\mathrm{N}=680)$ urskilja följande tre strategier för kompetensutveckling: 
”Lära-på-jobbet"-strategin,

som bygger på främst följande lärandeaktiviteter: kurser på arbetsstället, möten med personalen, studiebesök vid andra avdelningar, skapande av arbetslag samt arbete i projekt. Strategin betonar arbetet som den plats där kompetensen bäst utvecklas. I denna strategi ingår flera element. Grupper bildas, projekt skapas och möten arrangeras på arbetsstället för att kompetens ska förvärvas. Detta kan ses som en interaktiv strategi där kompetens förvärvas och används parallellt.

”Lära-sig-själv"-strategin,

som bygger på främst följande aktiviteter: kurser anordnade utanför arbetsstället, inköp av facklitteratur och självstudier. Strategin bygger på en klassisk syn på kompetens och lärande och innefattar vanligen tre tydliga steg; kurs bedriven av en kursanordnare utanför arbetsplatsen, inköp av litteratur samt självstudier. Strategin innebär att kompetens ska överföras från en lärare till en elev, och att kompetensen förvärvas utanför arbetsplatsen och den operativa verksamheten. Det är därför att betrakta som en linjär strategi där kompetens först förvärvas i ett steg och därefter används i ett andra steg;

"Lära-av-andra"-strategin,

som sker främst genom deltagande i nätverk och externa studiebesök. Denna strategi är något av en kombination av de två tidigare strategierna. Även här är arbetsplatsen av betydelse, men inte den egna utan andra, ofta liknande, arbetsplatser. Här är ambitionen att lära sig genom att se hur andra gör. En ofta använd metod för detta är vad som kallas "benchmarking".

Av dessa tre strategier dominerar "lära-sig-själv"-strategin (som i genomsnitt anges av $56 \%$ av de svarande), följt av "lära-på-jobbet"strategin (i genomsnitt $38 \%$ av svaren) och "lära-av-andra"-strategin, (29\% av svaren).

De ovan nämnda strategierna för kompetensutveckling kan naturligtvis kombineras, vilket också ofta sker i praktiken. Man kan till och med hävda att man bör eftersträva en integration mellan två eller flera de nämnda strategierna, för att underlätta ett kvalificerat lärande i det dagliga arbetet (se vidare avsnitt 2.4 nedan). Utifrån den ovan refererade utvärderingen (Svenska ESF-Rådet, 2003) kan man, något tillspetsat, säga att lära-sig-själv"-strategin leder till kompetensutveckling hos individen, men att dessa resultat inte nödvändigtvis blir vare sig bestående eller kommer verksamheten till godo. För att det senare ska bli fallet krävs även att den utvecklade kompetensen tas tillvara i den dagliga verksamheten. Detta förutsätter, i sin tur, exempelvis uppföljningar av de resultat som uppnåtts hos deltagande individer, samt ofta även förändrade arbets- 
uppgifter och därmed kanske även arbetsorganisatoriska förändringar. En möjlig slutsats av detta är betydelsen att arbeta med en integration av olika strategier. Detta för att säkerställa att den yrkeskompetens och det ökade intresse som utvecklas hos individen också uppmärksammas och tas tillvara i den dagliga verksamheten.

Betydelsen av att eftersträva en integration mellan olika strategier för kompetensutveckling stöds även av andra studier inom området. Exempelvis visar Rönnqvist (2001) utifrån en studie av kompetensutveckling inom hälso- och sjukvårdsorganisationer på betydelsen av att integrera informellt lärande i det dagliga arbetet med planerade utbildningsinsatser (se även Svensson \& Åberg, 2001).

\subsection{Varför satsar organisationer på kompetensutveckling?}

Varför satsar organisationer på utbildning och andra former för kompetensutveckling? Kan satsningar på kompetensutveckling förstås som kalkylerade och rationella överväganden, eller är sådana satsningar istället främst ett uttryck för opportunism och modetrender?

Flera studier av satsningar på kompetensutveckling i arbetslivet pekar på att olika yttre kontextuella faktorer kan ses som nödvändiga, men icke tillräckliga betingelser för att företag och organisationer skall sata på utbildning och andra former av kompetensutveckling. En relativt vanligt förekommande situation är att affärsmässiga (t.ex. produktutveckling) eller tekniska förändringar skapar en kompetensklyfta - de kompetens som efterfrågas finns bara i begränsad utsträckning hos den anställda personalen. Denna kompetensklyfta utgör oftast den faktor som, genom tämligen komplexa processer, kan leda vidare till satsningar på någon form av kompetensutveckling. (se t ex Pettigrew, Hendry \& Sparrow, 1988). Om det sedan faktiskt görs satsningar på kompetensutveckling eller ej avgörs av samspelet mellan ett stort antal faktorer i företagens yttre och inre kontext. Dessa resultat och slutsatser stödjs av annan empirisk forskning och teoribildning på området (se t ex Nordhaug, 1992).

Resonemanget ovan kan exemplifieras utifrån en svensk studie av utbildningssatsningar i 16 tillverkningsföretag (Hamngren, Laestadius \& Odhnoff, 1995). I denna studie belyses samspelet mellan yttre och inre drivkrafter för satsningar på kompetensutveckling. Särskilt nämns följande sju faktorer som betydelsefulla för att nå framgång:

- förekomsten av "eldsjälar”, dvs förändringsagenter (t ex linjechefer, arbetsledare, personalchefer eller fackliga företrädare) som håller idéerna levande, bär dem framåt och mobliserar andra att utveckla dem;

- högsta ledningens och chefernas aktiva stöd bl a för att legitimera arbetet;

- fackligt stöd; 
- utvecklingsprogrammet baseras på egen, intern kompetens samt planeras och genomförs på basis av bred delaktighet från de som berörs av programmet;

- målinriktade utbildningar utifrån tydliga mål;

- tillräcklig tid för programmets genomförande samt god "timing” av åtgärder;

- lönesystem som stöder kompetensutveckling.

I en fallstudie av kompetensutveckling i sju små- och medelstora företag visar Ellström \& Nilsson (1997) att olika yttre faktorer, och främst då lågkonjunkturen, varit viktiga drivkrafter när det gäller gjorda satsningar på utbildning. I det typiska fallet har en minskad orderingång med åtföljande ekonomiska problem och risk för permitteringar eller nedläggning initierat ett sökande efter olika vägar för att kunna upprätthålla och utveckla verksamheten. I flera av företagen har även ökade krav på lönsamhet, ökade kundkrav vad gäller t ex kvalitet och leveranstider eller ökade krav på personalens kompetens funnits med som motiv till gjorda satsningar på utbildning.

Liksom i de ovan refererade studierna var dock de yttre faktorerna inte tillräckliga för att förklara besluten om och inriktningen av gjorda satsningar på kompetensutveckling. Istället tyder resultaten på nödvändigheten av att beakta inte enbart omgivningsfaktorer, men även de föreställningar och intressen som ägaren/ledningen och andra aktörer inom företaget har, och som bestämmer vad man ser som det lämpliga, möjliga och önskvärda sättet att bedriva företagets verksamhet, inklusive de satsningar som görs på kompetensutveckling. Dessa slutsatser får ytterligare stöd och fördjupas i den uppföljning av fyra av de sju företagen som redovisas av Nilsson (2003). Utifrån denna uppföljande studie blir det tydligt hur satsningar på kompetensutveckling formas i ett samspel mellan omvärldsfaktorer (t ex ökad konkurrens eller förändrade kundkrav) och olika aktörer (ledning, fackliga företrädare och anställda) inom organisationen. Avgörande för vad det blir av de satsningar som görs är i hög grad styrkan i aktörernas intresse av att arbeta med kompetensutveckling, men även deras förmåga att tydliggöra och få gehör för sina intressen samt förmåga att driva utvecklingsprocesser. Här visas inte minst graden av tillit mellan ledning och anställda vara en betydelsefullfaktor för hur en satsning på kompetensutveckling kommer att utvecklas i företaget.

Sammanfattningsvis kan konstateras att de ovan redovisade forskningsresultaten tämligen samstämmigt betonar olika omvärldsfaktorers betydelse för hur organisationer arbetar med utbildning och kompetensutveckling. Samtidigt kan konstateras att ingen enda faktor eller grupp av faktorer (t.ex. teknikutvecklingen) kan utnämnas till den mest betydelsefulla eller i sista hand bestämmande faktorn för de satsningar som görs på kompetensutveckling. 
Av allt att döma kan istället gjorda satsningar på kompetensutveckling bäst förstås som ett resultat av ett komplext samspel mellan yttre krafter och de olika organisationsinterna "logiker" som olika aktörer representerar. Mycket talar också för att yttre faktorer (t ex ökade kundkrav eller minskad orderingång) skall ses som nödvändiga, men inte tillräckliga förutsättningar för företags satsningar på kompetensutveckling. Dessutom förefaller det vara betydelsefullt att det inom företaget finns en "god jordmån” för sådana satsningar, dvs att organisationen har en god lärandemiljö. Organisationens lärmiljö påverkas inte minst av ledningens och de fackliga organisationernas uppfattningar om värdet av utbildning, men även av de anställdas upplevda behov av kompetensutveckling och motivation för deltagande i utbildning.

\subsection{Vilka effekter kan uppnås av kompetensutveckling i organisationer?}

Forskning om effekter av utbildning och andra former av kompetensutveckling i organisationer är tämligen svagt utvecklat såväl teoretiskt som empiriskt. En stor del av den tillgängliga forskningen är inriktad på studier av utbildningseffekter, inte sällan i form av deltagares attityder till utbildning. Den vidare innebörd av begreppet kompetensutveckling som presenterats tidigare där i kompetensutveckling också inkluderades exempelvis lärande i det dagliga arbetet $-\mathrm{s}$ k informellt lärande - har endast i begränsad omfattning studerats från effektperspektiv. Detta speglas även i denna kortfattade översikt. Det är därför inte helt enkelt att besvara den i rubriken formulerade frågeställningen.

Hur kan vi då definiera och mäta effekter av kompetensutveckling? En fortfarande ofta använd indelning av effekter föreslogs av Kirkpatrick (1959; se även Kirkpatrick, 1996). Denna indelning bygger på en åtskillnad mellan fyra effekt- eller resultatnivåer, nämligen:

- deltagares attityder till och värdering av t ex en utbildning och dess resultat;

- effekter på individnivå i form av förvärvade kunskaper eller färdigheter, men även t ex i form av förändrade attityder (t ex inställning till utnyttjande av ny teknik);

- effekter i form av att individen blir bättre på att utföra vissa arbetsuppgifter ("job performance");

- effekter i form av förbättrade prestationer på verksamhetsnivå t ex ett arbetslags prestationer eller prestationer på organisationsnivå.

Generellt kan man förvänta sig att relationerna mellan dessa nivåer är komplexa och att effekter på olika nivåer samspelar med varandra. En närmast logisk självklarhet är att en positiv värdering av t ex en utbild- 
ning eller dess effekter hos deltagarna egentligen inte säger något om effekter på övriga nivåer (man behöver inte gilla en utbildning för att man ska lära sig något, omvänt betyder det faktum att deltagarna utrycker gillande för en utbildning inte nödvändigtvis att de lärt sig särskilt mycket, eller att det de lärt sig inte var vad som avsågs i målen för utbildningen). Ytterligare en mer generell reflektion som kan göras är att det naturligtvis är väsentligt lättare att uppnå positiva effekter på den första nivån än på den andra nivån. Liksom det är väsentligt mer komplicerat och krävande att uppnå effekter på den tredje eller fjärde nivån än på den andra nivån. Generellt måste man naturligtvis utfärda en stark varning för att tolka effekter på nivå ett (eller på någon annan nivå) som automatiska indikatorer på att effekter föreligger även på "högre” nivå.

Vilka är då effekterna av deltagande i kompetensutveckling? I en norsk studie redovisar Nordhaug (1985; se även Nordhaug, 1991) olika effekter av kompetensutveckling på individnivå. Undersökningen baseras på ett urval av individer ( $\mathrm{n}=299$ ). I fokus för analysen står individens behållning av olika former av utbildning. Utifrån en avancerad statistisk analys av enkätsvaren var det i denna studie möjligt att urskilja tre olika typer av effekter, nämligen att deltagande i utbildningen gett:

- motivation för fortsatt lärande (ökat intresse för fortsatt utbildning, ökat allmänt intresse för lärande, ökat intresse för ett visst ämne);

- möjligheter till karriärutveckling (främst befordran, intressantare arbete, ökad självständighet);

- möjligheter till psykosocial utveckling (främst ökat självförtroende, självförverkligande, nya vänner).

Som Nordhaug noterar är dessa tre faktorer intressanta inte minst utifrån den konventionella synen på kompetensutveckling i organisationer som förmedlare av mer specifika, arbetsrelaterade kunskaper och färdigheter. Resultaten från undersökningen pekar också mer "oväntade” resultat, exempelvis att en viktig effekt av kompetensutveckling är ökad motivation för lärande.

Dessa resultat stöds av senare studier. Ellström \& Nilsson (1997) kunde i den tidigare refererade studien av kompetensutveckling i små- och medelstora företag visa på följande typer av effekter på individnivå:

- ett ökat yrkeskunnande i termer av att man bättre klarar sina nuvarande arbetsuppgifter;

- $\quad$ ett ökat intresse att lära nytt i arbetet, dvs. en ökad motivation för lärande;

- att man fått en bättre helhetsbild av arbetet;

- att man fått ett större ansvar;

- att man trivs bättre i arbetet. 
Liknande resultat redovisas även av Gill, Kock \& Ellström (2005) i en studie av kompetensutveckling i små- och medelstora företag. I den senare studien framstår effekter i form av ökad motivation och intresse för att lära nytt som lika stora eller till och med större än de effekter som rapporteras i form av ökat yrkeskunnande.

Hur kan då förstå dessa resultat som visar att man förutom olika (kognitiva) effekter i form av ökade kunskaper och färdigheter kan förvänta sig olika typer av effekter kopplade till motivation, intresse och trivsel. Ett intressant resonemang kring dessa frågor förs av Tuomisto (1986) i en finsk undersökning, som menar att kompetensutveckling i arbetslivet vid sidan av effekter i form av kunskaper och yrkeskunnande även kan sägas ha "ideologiska" eller värderingsmässiga effekter. Han urskiljer tre typer av sådana värderingsmässiga effekter, nämligen:

- att öka verksamhetens legitimitet i de anställdas ögon, vad gäller bl a dess mål, grundläggande ideologi och maktstruktur;

- att öka de anställdas motivation och därmed förbättra deras arbetsprestationer, utan att behöva höja deras kompetens;

- att förbättra organisationens sammanhållning, klimat eller organisationskultur för att därmed skapa en "vi-anda” och en bättre uppslutning kring verksamhetens mål och värderingar.

Detta visar på en inneboende motsättning i kompetensutveckling. Å ena sidan kan personalutbildning ses som ett instrument för styrning och anpassning av de anställda till rådande förhållanden på arbetsplatsen eller i organisationen. $\AA$ andra sidan kan utbildningen samtidigt ses som ett instrument för att öka de anställdas intresse och beredskap för fortsatt lärande. Båda dessa tolkningar av vad kompetensutveckling kan innebära kan naturligtvis vara både riktiga och fullt förenliga. En viktig uppgift för fortsatt forskning är emellertid att närmare klargöra dessa funktioner och deras inbördes relationer.

Ytterligare en dimension av utbildningseffekter diskuteras av Ellström \& Nilsson (1997). Flera av de ovan nämnda effekterna kan sägas ha en anpassningsinriktad karaktär, dvs de avser ett ökat yrkeskunnande, ett ökat ansvar eller bättre trivsel i relation till nuvarande arbetsuppgifter. Andra effekter som vi kan kalla för utvecklingsinriktade effekter, innebär istället:

- att man fått mer kvalificerade arbetsuppgifter; eller

- att man fått ett ökat inflytande.

Dessa typer av effekter rapporterades dock endast av relativt få deltagare eller i större utsträckning endast från ett par av företagen. 
I en annan del av den ovan refererade norska undersökningen diskuterar Nordhaug (1985) vilka effekter personalutbildning kan få på organisationsnivå. Personalutbildning kan leda till såväl funktionella som dysfunktionella effekter på organisationsnivå. Som exempel på den förra kategorin antas utbildning fungera som mekanism för bl a:

- urval och mobilitet på den interna arbetsmarknaden i företaget;

- socialisering och social kontroll av anställda;

- legitimering av mål och beslut;

- förbättrad beslutsförmåga i organisationen;

- utveckling av medbestämmande och arbetsmiljö;

- utveckling av organisationens förändringsberedskap;

- en förbättrad motivation och lärandemiljö.

Som möjliga exempel på dysfunktionella effekter anges: "mismatch" mellan individens kompetens utvecklingsbehov och organisatoriska behov (t.ex. felutbildning, underutbildning, överutbildning), resursavtappning (braindrain) samt utveckling av kunskapsmonopol inom organisationen. Detta resonemang pekar på betydelsen av att i försök att mäta resultat av personalutbildning även uppmärksammar oavsiktliga och oplanerade effekter. Nordhaug (1985) redovisar dock ingen empirisk studie vad gäller effekter på organisationsnivå, utan söker indirekt stöd för sitt resonemang i annan forskning.

\subsection{Vad kännetecknar framgångsrika strategier för kom- petensutveckling?}

Få studier har försökt att studera frågan vad som kännetecknar framgångsrika strategier för kompetensutveckling. Ett annat sätt att formulera denna fråga är: Under vilka förutsättningar kan program för kompetensutveckling i organisationer förväntas leda till avsedda effekter. Flertalet av de studier som försökt belysa denna fråga utgörs av s k multipla fallstudier. Exempel på andra typer av studier finns dock också.

Framgång i genomförda satsningar på utbildning och andra former för kompetensutveckling i företag beror inte enbart på den strategi och de metoder som tillämpas. Naturligtvis är detta viktiga aspekter, men detta får inte undanskymma att forskningen inom området tämligen entydigt pekar på att uppnådda effekter av kompetensutveckling beror på ett samspel mellan:

- deltagarförutsättningar (tidigare erfarenheter av utbildning, självförtroende, motivation, kompetens); 
- utbildningens planering, innehåll, utformning (design) och genomförande;

- förutsättningar relaterade till verksamhetens inre kontext (lärmiljö), dvs faktorer kopplat till ledning, arbetsorganisation, organisationskultur etc.

\section{Deltagarförutsättningar}

Förutsättningar för vuxnas deltagande i utbildning är ett område som under de två senaste decennierna i hög grad stått i fokus för vuxenpedagogisk forskning. Beredskapen att delta och det faktiska deltagandet i olika former av vuxenutbildning är högst ojämnt fördelad i samhället, och starkt kopplad bl a till levnadsvillkor, familjebakgrund, tidigare skolgång och nuvarande arbetsförhållanden. Det är t ex ett välkänt faktum att beredskapen att delta i olika former av vuxenutbildning har ett samband med tidigare utbildningsnivå: ju högre utbildningsnivå, desto större är beredskapen att delta i och utnyttja möjligheter till fortsatt utbildning. Det har också visat sig vara svårt att, annat än marginellt, påverka eller kompensera för detta mönster genom olika former av reformer (Rubenson, 1996).

Vad specifikt gäller deltagande i kompetensutveckling i organisationer finns en rad studier som visar att ju mer kvalificerad position man har i arbetslivet, desto vanligare är det att man deltar i olika former av kompetensutveckling (Rubenson, 1996). Detta torde delvis, men inte enbart handla om att arbetsgivaren erbjuder utbildning främst till personal i nyckelfunktioner inom organisationen. Som visats av Larsson med flera (1986), har icke-facklärda arbetare med kort formell utbildningsbakgrund och arbetsuppgifter som ställer ringa krav på yrkeskompetens ofta en mycket snäv och instrumentell syn på utbildning. De saknar i hög grad motivation för att delta i utbildning om inte denna är direkt kopplad till krav i arbetet. Därmed efterfrågas inte heller utbildning, och beredskapen att delta i utbildning som erbjuds är sannolikt låg i stora grupper av anställda med kort utbildning och okvalificerat arbete.

I linje med dessa resultat diskuterar Illeris (2003; 2006; 2007) kortutbildade vuxnas grundläggande ambivalens inför deltagande i utbildningsaktiviteter. Kortutbildade är ofta mycket lågt motiverade för och har svårt att lära något av utbildningsaktiviteter som inte kan se meningen med utifrån deras eget perspektiv. Slutsatsen av detta resonemang är att det blir viktigt hur en utbildning introduceras och läggs upp (se vidare nedan).

Kan man då säga något mer specifikt om de faktorer som påverkar individers motivation för deltagande i utbildning? Viktiga faktorer, som betonats inte minst inom vuxenpedagogisk forskning (Rubenson, 1996) är syn på värdet av lärande och individuell utveckling; förväntat utbyte av gjorda satsningar; självförtroende i betydelsen tilltro till sin egen förmåga att lära. Dessa faktorer är i sin tur i hög grad relaterade till social bak- 
grund, utbildningsnivå, tidigare erfarenheter av olika typer av lärandesituationer, arbetsförhållanden samt ekonomisk, politiska och kulturella faktorer i samhället.

Maud Baumgarten (2006) visar i en nyligen publicerad studie hur anställdas deltagande i läraktiviteter på en arbetsplats sammanhänger med självförtroende, men även med en rad andra faktorer kopplade till arbetsförhållanden samt de anställdas inflytande i och över arbetet. Hon visar i denna studie på tre typer av deltagarmönster, och grupperar deltagande individer utifrån dessa mönster i tre grupper: de engagerade, de motvilliga och de osäkra. Den första gruppen, de engagerade, utmärktes av ett gott självförtroende som innebar att de inte tvekade att ta på sig nya uppgifter eller anta utmaningar. Deras aktiviteter innebar att de kom in i vad som i studien karakteriseras som "positiva lärspiraler". Gruppen de motvilliga gav uttryck för att de inte delade företagets mål bakom genomförda förändringar och satsningar på kompetensutveckling. Deras deltagande var begränsat, och deltagarmönstret tolkas som att de kommit in i en "negativ lärspiral”. Fokus för denna grupp ligger på fritiden och de aktiviteter som man då utför snarare än i arbetet. Gruppen de osäkra hade i flertalet fall arbetet länge inom företaget med enahanda arbetsuppgiftger, och med ett lågt inflytande i och över arbetet. Hur läraktiviteterna organiserades visade sig ha stor betydelse för denna grupps deltagande. Tillräckligt med tid för lärande samt handledning var viktiga faktorer för denna grupp. En slutsats av denna studie är således betydelsen av den typ av bakgrundsfaktorer som ovan påtalats. Men samtidigt sätts fokus även på betydelsen av delaktighet samt hur läraktiviteter organiseras, dvs. vad som i det följande kallas utbildningsrelaterade förutsättningar.

\section{Utbildningsrelaterade förutsättningar}

Vad gäller utbildningsrelaterade förutsättningar kan man utifrån tidigare forskning (se t ex Ellström \& Nilsson, 1997; Svenska ESF-Rådet, 2003; Kock, Gill \& Ellström, 2006) peka på en rad viktiga förutsättningar som sammanhänger med utbildningens planering, utformning (design) och genomförande. Ser vi först till utbildningens planering är det viktigt:

- att motiven för den gjorda satsningen är problemorienterade snarare än opportunistiska, dvs att kompetensutvecklingen ses som ett led i en strategi t ex för att stödja en förändra arbetsorganisation eller planerad ny produktion, och inte i första hand som ett sätt att få del av vissa stödresurser eller $\mathrm{t}$ ex för att kompetensutveckling allmänt sett "ligger i tiden";

- att personalen direkt eller indirekt, t ex via fackliga eller andra företrädare, i någon mening är delaktiga i planeringen av utbildningssatsningen (här kan man naturligtvis urskilja olika grader och typer av delaktighet). 
Vilka mer konkreta faktorer och förhållanden är då betydelsefulla för att nå framgång med satsningar på kompetensutveckling i en verksamhet? Såväl Ellström \& Nilsson (1997) som Illeris (2007) behandlar en rad i sammanhanget betydelsefulla faktorer. Samtliga dessa faktorer ligger nära den konkreta utbildningssituationen och hur den utformas. Exempel på betydelsefulla faktorer är:

- hur deltagarna kontaktas och rekryteras till en utbildning: det är av stor betydelse att detta sker på personlig basis, helst genom en person som den potentielle deltagaren känner sig trygg med;

- $\quad$ att den vägledning som sker inför en utbildning är personlig och sker i dialog, samt utgår från deltagarens perspektiv, upplevda problem och svårigheter - detta utan att vara manipulerande;

- att utbildningen sker på eller i direkt anknytning till arbetsplatsen, helt eller delvis under arbetstid och tillsammans med andra från samma arbetsplats - detta inte minst för att undvika deltagarnas associationer till kanske dåliga erfarenheter av skolan och att återigen tvingas "sitta på skolbänken";

- att undervisningen är målinriktad och aktiverande genom former (t ex projekt och grupparbete) som förutsätter medbestämmande och medansvar från deltagarnas sida - detta är viktigt även om undervisningen från början kanske sker med högre grad av lärarstyrning, något som ofta erfarenhetsmässigt förväntas av deltagarna;

- att utbildningen sker i samspel och bygger på en integration mellan lärande i arbetet och utanför det direkta arbetet, dvs. ett samspel mellan kursdelar och praktikdelar, där kursdelarna typiskt är kortare (några dagar upp till en vecka) och praktikdelarna längre;

- att praktikdelarna innehåller moment av undersökningar eller förändringar av arbetet (t ex i form av kortare projekt) som utgår från upplevda problem eller utbildningsbehov, och som man sedan kan lägga fram, diskutera och dra slutsatser av i en följande kursdel;

- att det finns en samverkan mellan arbetsplats och utbildningsarrangör;

- att deltagarna får någon form av "papper” på eller formell dokumentation (kursbevis) på den utbildning man genomgått och vad man lärt i form av kunskaper eller färdigheter;

- att det sker någon form av förändring när man återvänder till arbetet efter avslutad utbildning, så att det man lärt sig kommer att efterfrågas och kan få praktisk användning i arbetet;

- att gjorda satsningar är verksamhetsinriktade, dvs inriktade mot att fördjupa eller bredda de anställdas kompetens som ett medvetet led i en mer långsiktig affärs- eller verksamhetsutveckling ( $\mathrm{ex}$ införande av målstyrda grupper), snarare än individinriktade, dvs inriktade mot att öka de anställdas kompetens, men utan eller med endast lös koppling till verksamhetens utveckling 
Förutsättningar relaterade till organisationens inre kontext och lärmiljö

Med inre kontext avses här olika faktorer relaterade till produktionsorganisation, arbetsuppgifternas karaktär, ledning etc. Vi ska här kortfattat peka på några faktorer som, utifrån tidigare forskning (Ellström \& Nilsson, 1997; Hamngren, Laestadius \& Odhnoff, 1995; Pettigrew m fl, 1988), förefaller vara av särskild vikt för att uppnå avsedda effekter av satsningar på kompetensutveckling i organisationer.

För det första visar dessa och andra studier att effekterna av genomförd kompetensutvecklinmg tycks sammanhänga med förutsättningarna för lärande i det dagliga arbetet. I de företag som utmärks av en relativt sett god lärmiljö (t.ex. genom att arbetsuppgifternas komplexitet kräver ett kontinuerligt lärande) rapporteras i högre grad effekter än i de företag där förutsättningarna för lärande i arbetet inte framstår som lika gynnsamma. Företag som rapporterar goda utbildningseffekter tycks dessutom i högre grad än övriga företag ha en verksamhet som karakteriseras av:

- att mer tid har avsatts för olika utbildningsaktiviteter;

- att betydelsefulla aktörer inom företaget, främst ledning och fackliga företrädare, ser utbildning och lärande som ett både effektivt och legitimt sätt att hantera företagets problem/utmaningar, dvs att verksamheten genomsyras av en stark tilltro till och ett reellt engagemang för utbildning och lärande som betydelsefulla för företagets utveckling och överlevnad;

- förekomsten av "eldsjälar”, dvs förändringsagenter (t ex linjechefer, arbetsledare, personalchefer eller fackliga företrädare) som håller idéerna levande, bär dem framåt och mobliserar andra att utveckla dem.

Vad utmärker då en god lärmiljö? På denna punkt finns en tämligen god överensstämmelse mellan olika forskare vad gäller betydelsen av bland annat följande förhållanden (se t ex Ellström, 2004; Holt Larsen med flera, 2002; Skule \& Reichborn, 2002):

1. Att arbetsuppgifterna främjar lärande genom:

a) att det finns variation i arbetet vad gäller vad man gör, hur, med vem, var och när;

b) att man får feedback (återkoppling) på utfört arbete;

c) att det finns en autonomi (frihetsgrader) i tolkning och utförande av arbetet;

d) att arbetsuppgifter delegeras;

e) att det finns möjligheter att utveckla ett helhetsperspektiv;

f) att det finns möjligheter att lära av fel och misstag.

2. Att det finns stöd för lärande i det dagliga arbetet genom t ex:

a. erfarenhetsträffar;

b. handledning, inkl kollegial handledning; 
c. "miniprojekt” med fokus på ständiga förbättringar;

d. efterfrågestyrda utbildningsinsatser.

3. Att verksamhetens kultur utmärks av:

a) öppenhet och tillit snarare än rädsla eller ängslan;

b) en betoning av initiativ och risktagande;

c) en tolerans för olikheter, osäkerhet och fel;

d) uppmuntran av alternativtänkande och (om-)prövning av etablerade tanke- och arbetssätt.

4. Att verksamheten organiseras både för produktion och för lärande (utveckling), vilket bl a kräver att tillräcklig tid och andra resurser avsätts för lärande- och utvecklingsaktiviteter'

5. Att ledningen på samtliga nivåer i verksamheten förstår betydelsen av och har kompetens att arrangera för och stödja lärande-och utvecklingsprocesser.

I relation till de två sistnämnda punkterna är det en återkommande observation i många verksamheter att utvecklingsinriktade aktiviteter tenderar att "drunkna" i vardagens rutiniserade verksamhet. Det finns också en dubbelhet i en sådan rutinisering. A ena sidan kan man se rutiner som ett sätt att skapa den stabilitet och förutsägbarhet som utgör en viktig förutsättning för en effektiv verksamhet (och för utveckling av denna verksamhet). Å andra sidan försvårar rutiniseringen ett lärande som innebär nytänkande och förnyelse för såväl individer som verksamheter. För att främja ett utvecklingsinriktat lärande krävs istället ofta ett brott med etablerade rutiner och vanemönster. För att detta skall ske krävs många gånger att vi ställs inför krav på förändring i form av någon ny, närmast "krisartad" problemsituation (se vidare Ellström, 2004).

Detta ligger väl i linje med de forskningsresultat som redovisades ovan i avsnitt 4.2, nämligen att en rad studier av lärande och kompetensutveckling i organisationer pekar på att initieringen av sådana processer många gånger förutsätter ett utifrån kommande omvandlings- eller förändringstryck, exempelvis i form av en förändrad konkurrenssituation; snabb teknisk utveckling; ökade kvalitetskrav; tydliga krav från kunder/klienter, kollegor eller ledning. Samtidigt kan man emellertid även peka på resultat som tyder på att även om ett starkt förändringstryck är nödvändigt, så är det knappast en tillräcklig förutsättning för att etablerade rutiner skall brytas och för att ett utvecklingsinriktat lärande skall initieras. Vad som krävs är dessutom olika typer av stöd och resurser för lärande. Detta inte minst för att skapa den trygghet och tillit som är nödvändig för att balansera den osäkerhet och oro som varje mer genomgripande förändring innebär för individer och kollektiv. Här har ledningen en viktig roll för att aktivt stödja och stimulera de anställda att engagera sig i lärande- och utvecklingsaktiviteter kopplat till det dagliga arbetet. Med andra ord, vi bör inte förvänta oss att de möjligheter till lärande och utveckling som finns i ett visst arbete kommer att realiseras med någon 
slags automatik, istället krävs ett brett spektrum av uthålliga utvecklingsinsatser.

I förlängningen av detta resonemang kommer man in på förhållandet mellan informellt lärande i det dagliga arbetet och formella, planerade utbildningsinsatser. Som redan berörts ovan finns mycket som talar för att det informella lärandet många gånger förutsätter ett "kognitivt stöd” i form av lämpligt utformade formella utbildningsinsatser. Denna argumentation stöds även av empiriska studier av vad som kännetecknar framgångsrika strategier för kompetensutveckling i organisationer (Rönnqvist, 2001; Skule \& Reichborn, 2002; Svensson, Jakobsson \& Åberg, 2001).

\subsection{Avslutande kommentarer}

Av allt att döma kan satsningar på kompetensutveckling i organisationer bäst förstås som ett resultat av ett komplext samspel mellan yttre krafter och olika interna "logiker" som olika aktörer inom organisationen representerar. Mycket talar också för att yttre kontextuella faktorer (t ex ökade kundkrav eller minskad orderingång) skall ses som nödvändiga, men inte tillräckliga betingelser för företags satsningar på kompetensutveckling. Dessutom torde krävas att det inom företaget finns en "god jordmån”, dvs en god lärandemiljö, för sådana satsningar. Hit hör, som också visats i ovan refererade studier, inte minst förekomsten av en "utbildnings-" eller "lärandekultur" inom organisationen. En sådan kultur är beroende av bl. a. ledningens och de fackliga organisationernas uppfattningar om värdet av utbildning, men även av de anställdas upplevda behov av kompetensutveckling och motivation för deltagande i utbildning.

En annan viktig faktor för uppkomsten av en utvecklingsstödjande lärmiljö är personalens utbildningsnivå och företagets (och personalens) tidigare erfarenheter av kompetensutveckling. I en norsk studie (Nordhaug \& Gooderham, 1996) beskrivs förekomsten av en slags "kompetanseutviklingens jernlov", vilken bl.a. innebär att kompetensutveckling tenderar att efterfrågas i högre grad i företag där personalen har en högre utbildningsnivå. Omvänt gäller också, som berördes ovan, att vuxna med kort formell utbildning tenderar att ha en ambivalent eller rent av negativ inställning till deltagande i satsningar på kompetensutveckling (Illeris, 2007). Denna dynamik kan naturligtvis bidra till ökande utbildningsklyftor inom en verksamhet, men därmed även inom samhället i stort. En annan sida av den ovan nämnda "järnlagen” är att gynnsamma erfarenheter av kompetensutveckling tenderar att skapa krav på ytterligare kompetensutveckling, och på motsvarande sätt kan mindre lyckade satsningar på kompetensutveckling leda till en minskad efterfrågan på kompetensutveckling. Vi kan således genom vad vi gör i en verksamhet när det gäller satsningar på kompetensutveckling bidra till att skapa såväl goda som 
onda cirklar - cirklar som främjar eller hämmar utveckling av de anställda och av verksamheten.

\section{Referenser}

Ellström, P.-E. (2004). Reproduktivt och utvecklingsinriktat lärande. I: P.E. Ellström, \& G. Hultman (red.), Lärande och förändring i organisationer. Om pedagogik i arbetslivet. Lund: Studentlitteratur.

Ellström, P.E. \& Nilsson, B. (1997). Kompetensutveckling i små- och medelstora företag. En studie av förutsättningar, strategier och effekter. Linköping: CMTO och Institutionen för pedagogik och psykologi, Universitetet i Linköping, LiU-PEK-R-199.

Gill, A., Ellström, P.-E., \& Kock, H. (2005). Competence Development in Small and Medium Sized Enterprises (SMEs). Paper presented at the European Conference on Educational Research (ECER), Dublin, September 810, 2005.

Hamngren, I., Laestadius, S. \& Odhnoff, J. (1995). Effektivare produktion. Utbildningens roll för framgångsrika arbetsorganisationsförändringar. Stockholm: Inst. för Industriell Ekonomi och organisation. KTH.

Holt Larsen, H. med flera (2002). Læring på jobbet. Et Overblick. KL og KTO.

Illeris, K. (2003). Voksenuddannelse og voksenlæring. København: Roskilde Universitetsforlag.

Illeris, K. (2006): Læring. København: Roskilde Universitetsforlag.

Illeris, K. (2007). De kortuddannede voksenuddannelsernas største problem. Dansk Pædagogisk Tidsskrift

Kirkpatrick. D.L. (1959). Techniques for evaluating training programs. Training and Development Journal, 13, 11, 3-9.

Kirkpatrick, D.L. (1996). Invited reaction: Reaction to Holton Article. $\mathrm{Hu}$ man Resource Development Quarterly, 7, 1, 23-26.

Kock, H., Gill, A., \& Ellström, P.-E. (2006). Strategies for Competence Development at the Workplace: Lear- ning Environments and Learning Outcomes. Paper presented at the European Conference on Educational Research (ECER), Geneva, September 13-15, 2006.

Larsson, S., Alexandersson, C., Helmstad, G., \& Thång, P.-O. (1986). Arbetsupplevelse och utbildningssyn hos icke facklärda. Göteborg: Göteborg Studies in Educational Sciences 57.

Nilsson, B. (2003). Förändringsdynamik. En studie av utvecklingsprocesser i fyra småföretag.

Linköping: Linköping Studies in Education and Psychology No. 93, Linköpings universitet.

Nordhaug, O. (1985). Effekter av personalopplaering. Trondhiem: Norsk voksenpedagogisk institutt.

Nordhaug, O. (1991). The Shadow Educational System. Adult Resource Development. Oslo: Norwegian University Press.

Nordhaug, O. (1992). Human Capital in Organizations. Competence, Training and Learning. Oslo Scandinavian University Press.

Nordhaug, O., \& Gooderham, P.N. (1996). Kompetenseutvikling i næringslivet. Oslo: Cappelen Akademisk Forlag.

Pettigrew, A. M., Hendry, C. och Sparrow, P. R. (1988). Training in Britain. A Study of Funding, Activity and Attitudes. Employers' Perspectives on Human Resources. London: Training Agency, HMSO.

Rubenson, K. (1996). Livslångt lärande - mellan utopi och ekonomi. I P.-E. Ellström, B. Gustavsson \& S. Larsson (red.) (1996). Livslångt lärande. Lund: Studentlitteratur.

Rubenson, K. (2003). Adult Education and Cohesion. Lifelong Learning in Europe, 8, 1, 23-31.

Rönnqvist, D. (2001). Kompetensutveckling i praktiken - ett samspel mellan ledning, yrkesgrupper och om- 
värld. Linköping: Linköping Studies in Education and Psychology No. 81, Linköpings universitet.

Skule, S., \& Reichborn, A. N. (2002). Learning-conducive work. A survey of learning conditions in Norwegian workplaces. Cedefop Panorama series; 30. Luxembourg: Office for Official Publications of the European Communities.

Svenska ESF-Rådet (2003). Halvtidsutvärdering av Växtkraft Mål 3 i Sverige. Stockholm: Svenska ESF-Rådet.
Svensson, L., Jakobsson, E., \& Åberg, C. (2001). Utvecklingskraften i nätverk. Om lärande mellan företag. Stockholm: Santérus Förlag.

Svensson, L. \& Åberg, C. (2001). Elearning och arbetsplatslärande. Borås: Bilda förlag.

Tuomisto, J. (1986). The Ideological and Sociohistorical Bases of Industrial Training. Adult Education in Finland, 23, 3-24. 



\title{
5. Seks cases fra de nordiske lande - i kort og redigeret form
}

\author{
Case 1: Læring der forbedrer praksis i arbejdet. Under- \\ visning med interventionssigte: at støtte arbejdspladsens \\ forandringsprocesser
}

Case af lektor Hanne Dauer Keller. Redigeret ved Steen Høyrup

\section{Baggrund. Problem og sigte}

Det foreliggende projekt indgår i et mere omfattende projekt - KOMUD-projektet - der har til formål at skabe viden om, hvorledes efteruddannelse kan bidrage til erhvervsmæssig udvikling i udkantsområder. Fokus er på, hvorledes uddannelsesinstitutioner i højere grad kan bidrage til at udvikle viden til gavn for medarbejdere og ledelse i virksomheder. Udannelsens planlægning, form og indhold skal være baseret på virksomhedens behov, udviklingsbehov og aktuelle problemer. Mål for undervisningen er ikke at medarbejderne skal lære et fag isoleret - i dette tilfælde faget Kommunikation \& Samarbejde - men at arbejde med faget som redskab til at støtte arbejdspladsens forandringsprocesser. Sigtet er ikke læring for læringens skyld, sigtet er læring der kan forbedre praksis på arbejdspladsen.

\section{Arbejdspladsen}

N. Graversen Metalvarefabrik A/S er beliggende i Balling i Jylland. Der er ca. 70 personer ansat i produktionen og de er hovedsagelig mellem 40 og 60 år. Ca. 2/3 er ufaglærte. Det er en mandearbejdsplads med kun få kvinder.

Graversen er underleverandør til en række virksomheder og producerer forskellige metalvarer, primært emfang. Graversen mærker en øget konkurrence, men p.t. ingen nedgang i produktionsbehovet.

Graversen har påbegyndt en outsourcing af visse dele af produktionen til en fabrik i Ukraine, som virksomheden selv er ved at etablere. Virksomhedens force er de mindre serier og derfor vil en fabrik i Ukraine, der kan producere større serier, være et supplement til kerneydelsen.

Arbejdet beskrives af medarbejderne som varieret og tilpas udfordrede. Det kan være meget stressende i perioder, hvor der er deadlines, der 
skal nås. De fleste føler ikke deres arbejde truet af fabrikken i Ukraine, men medarbejderne tænker naturligvis over situationen.

Der arbejdes alene eller i mindre grupper og der roteres i mindre grad. Der er dog behov for større funktionel fleksibilitet i fremtiden: Det er en proces, der er skudt i gang, men som forløber noget trægt.

Arbejdet planlægges og styres af værkførerne, men man går mere over til moderne ledelse: Som en medarbejder udtrykker det: I dag skal man motivere og få det til at fungere som en gruppe, en helhed, hvor alle medarbejderne skal have mere ansvar.

Mht. til uddannelse har ledelsen den holdning, at medarbejderne ikke lærer de faglige færdigheder som f.eks. at svejse via kurser. Derfor er holdningen at læring sker gennem øvelse på arbejdspladsen, hvorved de ufaglærte bliver tillærte. Kurser er heller ikke effektive, hvis det handler om at få den nyeste tekniske viden: Mellemledelsen vurderer, at virksomheden rent teknologisk er langt foran de tekniske skoler, der ikke vil kunne tilføre arbejdspladsen noget på det tekniske felt. Den nyeste teknologiske viden får virksomheden fra leverandører af ny teknologi til virksomheden.

Der har været afholdt interne kurser i kendskab til A og B-kunder med en ekstern konsulent: Medarbejderne vurderer det således: „De faglige kurser kan vi ikke bruge til noget, men omkring de bløde værdier, der har vi ikke de kompetencer som andre har og da må vi bruge eksterne“.

Især de ufaglærte medarbejdere efterlyser kurser, der kan give dem mere grundlæggende viden om det, de arbejder med. En medarbejder udtrykker det således: „, Nogle gange efterlyser vi uddannelse, for vi bliver hevet ind fra gaden og så oplært og vi får ikke mere viden, end den person har der oplærte os. Så nogle gange står vi med håret i postkassen, for du gør nogle ting, du har fået vist, men du ved egentlig ikke hvorfor, så da synes vi mange gange, at vi mangler noget“.

\section{Strategi og metode: Hvad gjorde man?}

Der gennemføres et undervisningsforløb - et kursus - placeret uden for arbejdspladsen, med deltagelse af hele gruppen af produktionsmedarbejdere. Endvidere er mellemledelsen (værkførere) og topledelsen repræsenteret i dele af forløbet. Kurset er tidsmæssigt struktureret som 5 hele dage a 8 lektioner, altså 40 timer i alt. I kurset er der lærer fri perioder - i alt 9 timer fordelt over 3 dage, hvor kursisterne arbejder med planlagte opgaver. Kurset er opdelt i to perioder: 2 dage og 3 dage, med ca. 8 ugers pause imellem. Kursets første to dage vægter det alment personlige i et bredt livsperspektiv, medens de 3 sidste dage orienterer sig mere mod arbejdslivet. De fleste deltagere er uvante med at deltage i kurser. Der bliver gennemført 8 hold med 8-9 personer pr. hold.

Kursusforløbet har et dobbelt sigte: En faglig del, der handler om samarbejde og kommunikation, og en socialiserende del, der handler om at ændre medarbejdernes holdninger og forventninger til arbejdspladsen 
Formålet med kursus inden for faget Samarbejde og Kommunikation er ikke, at medarbejderne skal lære faget isoleret, men at anvende faget til at understøtte en organisatorisk forandringsproces på arbejdspladsen.

Formålet er således dobbelt:

- en almen personlig udvikling

- at understøtte arbejdspladsens organisatoriske forandringsprocesser

Strategien er karakteriseret ved flg. elementer:

- Uddannelsesinstitutionens rolle: organisationskonsulent i stedet for leverandørrolle

- Overskridelse af grænsen mellem uddannelsesinstitution og arbejdslivet. Læreren overskrider grænsen ved at undersøge deltagernes og arbejdspladsens behov, ved at inddrage materiale fra virksomheden i undervisningen, og ved at tilbyde og indgå i en opfølgning. Grænse overskrides ved at læreren tænker virksomhedens behov ind i undervisningen og se undervisningen som et led i en organisatorisk forandringsproces. Ledelsen overskrider grænsen ved at bevæge sig ind i undervisningens rum ved at deltage i hvert holds fremlæggelse af mål ved kursets afslutning.

- Samarbejde mellem uddannelsesinstitution og virksomheden: I samarbejdet er der fokus på rammer om undervisningen og de overordnede mål

- Kortlcegning af kompetenceudviklingsbehov: Undersøgelse i projektstarten af virksomhedens aktuelle situation og behov og kompetenceudviklingsbehov. Aktørerne fra uddannelsesinstitutionen indgår i en dialogisk proces med virksomheden omkring kompetencebehov og uddannelsesplanlægning. VUC er en aktiv medskaber af virksomhedens uddannelsesbehov.

- Fokus på samspil mellem undervisningsrummet (temporært socialt system) og arbejdspladsen (det permanente sociale system), herunder:

- Opfølgningsproces: videreførelse af læringsprocessen i en opfølgningsproces, hvor der arbejdes på at prioritere og indfri mål. Medarbejderne skal - som et led i kurset - formulere nye mål for deres arbejde, og ledelsen skal støtte implementeringen af disse mål.

- Kortlægning af arbejdspladsens uddannelsesbehov, problemer og udfordringer, - som grundlag for undervisningen. (jfr. ovenstående).

- Uddannelsen har et interventionssigte: manifesterer sig bl.a. i målsætning og follow-up. Både ledelse og medarbejdere anskuer formålet med undervisningen ud fra en virksomhedslogik.

- Selve undervisningen præges af:

- Fleksibilitet og tilpasning af undervisningen i forhold til arbejdspladsens situation og behov. 
- Nær sammenhæng mellem teori og praksis Arbejde med case baseret undervisningsforløb, til integration af teori og praksis

- Dialogbaseret undervisning

- Lærerrollen:

- læreren skaber konstant forbindelse mellem teorien og kursisternes hverdagsliv/arbejdsliv, via eksempler og dialog omkring disse.

- læreren arbejder med holdninger og provokerer kursisternes holdninger frem. Eksponering og diskussion af holdninger.

- læreren overskrider de traditionelle grænser mellem uddannelsesinstitutionen og arbejdslivet ved på forhånd at undersøge deltagernes behov (gennem interviews) og undervejs at inddrage materiale fra virksomheden i undervisningen og efter kurset at tilbyde konsulentbistand i forbindelse med opfølgningen.

- skolastiske eksempler nedtones og praktiske fremhæves af læreren.

- Kursist rolle: det er ikke vigtigt at kursisterne demonstrerer at de „kan stoffet“ og „kommer med de rigtige svar“, men:

- Refleksion: det er væsentligt at kursisterne reflekterer over deres egen kommunikation og samarbejde i dagligdagen på arbejdet.

- Indhold: der er fokus på at støtte processer i virksomheden, der kan forbedre produktiviteten

- Tilrettelæggelsesformen er organiseret som en vekslen mellem dialogbaseret undervisning, traditionel gennemgang af stof, og øvelser. Der indgår gruppearbejde, bl.a. i perioder med lærerfri undervisning, hvor grupperne arbejder selvstændigt med opgaver, der er nøje tilrettelagt af læreren. Kurset veksler således mellem lærerstyret undervisning og gruppearbejde. Der lægges vægt på at deltagerne kan anvende deres erfaringer til at diskutere opgaverne og arbejde med casene

- Medarbejderindflydelse. Medarbejderne har indflydelse på undervisningsforløbet og på påvirkningen af udviklingsprocessen på arbejdspladsen, i den efterfølgende follow up og implementering af mål fra kurset. Der indgås aftale med ledelsen om at acceptere en bottom-up proces, hvor medarbejderne selv er med til at formulere mål og at sikre, at der følges op på målene ved at forpligte ledelsen på at lytte til forslagene. Det ideelle - der ikke til fulde realiseres i denne case er, at inddrage medarbejderne i alle faser af projektet, for at sikre sig medarbejdernes opbakning til forløbet.

- Motivation. Medinddragelse og medindflydelse giver motivation. Det er motiverende, at deltagerne kan se meningen med kurset. Tidlige erfaringer med at undervisningen forløber på en spændende og relevant måde virker motiverende for deltagelsen i forløbet. Motivationen øges hvis medarbejderne i opfølgningerne oplever, at de ønskede ændringer realiseres. 
Opfølgning.

Forløbet for medarbejderne blev fulgt op af et seminar for ledelsen, hvor læreren og projektlederen fra VUC formidlede deres viden om organisationen (arbejdspladsen) til ledelsen, og støttede ledelsen i det videre arbejde med organisationen. Det blev aftalt at gå videre med 5 mål for udviklingen af arbejdspladsen, formuleret på kurset, og det blev aftalt at anvende læreren fra undervisningsforløbet som konsulent i denne proces. Det første mål handler om at arbejde med information.

De 5 mål var:

Information

Arbejdsforhold og trivsel

Opkvalificering og uddannelse

Samarbejde og kommunikation

Effektivitet og planlægning.

Strategien er især karakteriseret ved to nøglebegreber. Et kernebegreb er fleksibilitet/tilpasning i tilrettelæggelsen og gennemførelsen af uddannelsesforløbet: fleksibilitet/tilpasning betyder, at undervisningens forskellige hovedelementer tilpasses til arbejdspladsens situation og behov. Arbejdspladsens situation influerer afgørende undervisningens mål, form, indhold, lcererrolle, rammerne for undervisningen, osv.

Det andet kernebegreb er samarbejde mellem uddannelsesinstitution og virksomheden.

Samarbejdet består af følgende elementer:

- Planlægning af kurset og udformningen af de overordnede mål

- Kortlægning og analyse af virksomhedens aktuelle problemstillinger, udfordringer og uddannelsesbehov, for at give kurset en bestemt retning. Grundlaget herfor er en dataindsamling på virksomheden, med repræsentanter for forskellige niveauer i organisationen. Underviserne/konsulenterne beskriver sig selv som „aktiv medskaber af virksomhedens uddannelsesbehov“. Dette bygger på at virksomhedens repræsentanter ofte har begrænsede forestillinger om kompetenceudviklingsbehovet og manglende ekspertise mht. planlægning af læreprocesser. Dette er forståeligt idet kompetenceudvikling som fagligt felt kan beskrives som et blødt defineret og svagt struktureret kundskabsfelt, hvilket betyder at ,det på forhånd kan være vanskeligt at bestemme, præcist hvilke kundskaber der er nødvendige for at løse problemet på en tilfredsstillende måde“. Derfor er der behov for at aktørerne på uddannelsesområdet kan indgå i en dialogisk proces med virksomheden omkring kompetencebehov og uddannelsesplanlægning. Uddannelsesinstitutionen skal spille aktivt med i selve analysen af kompetenceudviklingsbehovet. 
- Undervisningen har indbygget et interventionssigte. Dette implicerer en række aktiviteter og dispositioner: medarbejderne arbejder med mål for arbejdspladsen, fremlæggelse af mål og dialog med ledelsen, værkførernes deltagelse i kurset.

- Opfølgning på undervisningen: Hver gruppe har undervejs i undervisningen formuleret tre mål, som de ønsker der arbejdes videre med på virksomheden. Der formuleres hvad, der er målet, hvorfor de mener at netop dette mål er vigtigt, og endelig hvordan de tænker målet udført i praksis.

\section{Planlægning af undervisningsforløb}

Den overordnede planlægning af undervisningsforløbet gennemføres med deltagelse af VUC (uddannelsesinstitutionen) ved projektleder og lærer. Fra virksomheden deltog den økonomiansvarlige og en værkfører. Medarbejderne i produktionen var altså ikke repræsenteret. Der var betænkeligheder ved dette, men tillid mellem VUC og arbejdspladsen, og internt på arbejdspladsen bevirker at problemet - at den deltagende medarbejdergruppe ikke er involveret fra start i den overordnede planlægning overvindes.

I det indledende planlægning bliver projektets mål og organisering drøftet.

Uddannelsesinstitutionen - VUC - har en meget aktiv rolle i planlægningsforløbet, og argumenterer for, og kommer igennem med, en række vigtige elementer der skal indgå i projektet:

- Medarbejderne skal som et led i kurset formulere nye mål for deres arbejde.

- Ledelsen skal være til stede ved undervisningsforløbets afslutning og skal lytte til medarbejdernes fremlæggelse af mål.

- Mellemledelsen - værkførerne - skal også deltage i kurset.

Den særlige tilrettelæggelse af undervisningen - i forhold til arbejdspladsen

Mål:

Kursusmål er mål for virksomhedens udvikling. På kurset formulerer medarbejderne mål for virksomheden, mål for deres arbejde. Ledelsen skal lytte til målene, forholde sig til dem, prioritere dem og følge op på målene. Målene anskues både af ledelse og medarbejdere ud fra en virksomhedslogik.

Virksomheden havde opstillet følgende mål for undervisningsforløbet:

- at blive bedre til at samarbejde og kommunikere på alle niveauer

- at tage ansvar for helheden

- at ansvar rækker længere end ens egne opgaver

- $\quad$ at sætte ord på holdninger 
- at finde og bruge de nødvendige ressourcer i samarbejdet

- at skabe motivation for medarbejderinvolvering

- $\quad$ at øge arbejdsglæden og skabe korpsånd

Indhold:

Med udgangspunkt i deltagernes personlige og arbejdsmæssige erfaringer har undervisningen bl.a. indeholdt følgende emner:

Selvværd/selvtillid, transaktionsanalyse, herunder hensigtsmæssig ctr. konfliktskabende kommunikation, kropssprog, OK-positioner, herunder holdninger og holdningsændringer, grupper, personlighedstyper, ressourcer, roller, psykisk arbejdsmiljø, herunder stress, ledelsesformer, motivation, fleksibilitet/omstillingsparathed, konfliktløsning.

Eksamen:

Eksamen erstattes af fremlæggelse af mål, dvs. fremlæggelse af ønsker mht. ændring af praksis på arbejdspladsen.

Tidsmæssig placering og omfang:

Kurset placeres i arbejdstiden. Da det ikke er muligt for virksomheden, af hensyn til produktiviteten, at undvære et større antal medarbejdere samtidig, gennemføres undervisningen i 8 hold, med 8-9 medarbejdere på hvert hold. Ét hold ad gangen er på kursus en hel dag i arbejdstiden.

Kurset forløber over i alt 5 dage af 8 timer i foråret 2005.

Deltagere:

Deltagere på kurset udgøres af hele gruppen af produktionsmedarbejdere, samt nogle værkførere.

Organisering af undervisningsholdene:

Undervisningen foregår på mindre hold, der dannes på tværs af strukturerne (afdelingerne) på arbejdspladsen, således at udveksling af erfaringer og videndeling ikke holdes inden for afgrænsede enheder, men kan foregå på tværs af skellene i virksomheden.

Planlægning og styring af projektet:

Efter forslag fra VUC bliver man enig med virksomhedsledelsen om en bottom-up-proces, hvor medarbejderne selv er med til at formulere mål, og ledelsen forpligter sig til at forholde sig til målene, og følge op på dem. Herudover foregår planlægningen med løbende kontakt med ledelsen om formulering af de overordnede mål, ligesom planlægningen baseres på interview med repræsentanter for alle niveauer i virksomheden.

Analyse af virksomhedens uddannelsesbehov:

Der finder - som ovenfor beskrevet - en grundig analyse sted af virksomhedens uddannelsesbehov. 


\section{Resultat og effekter}

Forskeren vurderer, at der ses effekter på to planer:

- Det individuelle niveau: det faglige og personlige niveau

- Det sociale/organisatoriske niveau

Det individuelle niveau, medarbejderne:

Forskerne kan her konstatere en medlæring, dvs. en læring der er afgørende influeret af selve arbejdsmåden, den aktive og dialogbaserede arbejdsmåde:

- Ny tillid til at kunne øve indflydelse på arbejdspladsen

- Ønske om at præge arbejdspladsen

Der er her tale om holdningsændringer

På det sociale/organisatoriske niveau, medarbejderne, nævnes:

- Mmedarbejderne har fået viden om andre dele af virksomheden, end den afgrænsede del der udgør deres daglige arbejde.

- Medarbejderne har skabt personlige relationer til andre medarbejdere i andre afdelinger. Dette ses både som en effekt af gruppesammensætningen, men især en effekt af den dialogprægede undervisning, hvor mange deltog aktivt og derved åbnede sig for hinanden og lærte hinanden at kende

Ledelsen:

- lærer en del om medarbejderne i organisationen. Erhverver viden om medarbejdernes oplevelser af vanskeligheder i arbejdet, og medarbejdernes forslag til forbedringer af virksomheden.

\section{Referencer}

Dybdal, Lise: Kvalitetsudvikling VUC i Viborg Amt. Tilrettelæggelse af undervisning i Samarbejde og Kommunikation på private virksomheder. December 2005
Hanne Dauer Keller \& Marianne Kemény Hviid, Aalborg Universitet, Department of Education, Learning and Philosohy: Den vanskelige voksenuddannelse: Læring mellem undervisnings- og arbejdslogik. Oplæg ved NFPF 2006 i Órebro. 


\title{
Case 2. Work smarter not harder: Udvikling af den men- neskelige side af virksomheden gennem integration af læring, refleksionsprocesser, videndeling og udviklings- processer på virksomheden.
}

\author{
Dansk case 2, ved Steen Høyrup
}

\section{Baggrund. Problem og sigte}

Kernen i denne case er en virksomhed inden for procesindustri, der over en længere årrække (ca. 15 år) systematisk har arbejdet med at udvikle den menneskelige side af virksomheden i takt med udviklingen af den teknologiske side af virksomheden, således at arbejdspladsen til stadighed optimerer og balancerer den menneskelige og den tekniske side af virksomheden.

Målet er således at udvikle den menneskelige side af virksomheden, der udgøres af:

- Individer, de enkelte medarbejdere. Udvikling her drejer sig om medarbejderudvikling/ kompetenceudvikling.

- Udvikling af arbejdsorganiseringen på virksomheden, så denne både er effektiv mht. produktion, men fokus her er nok så meget på den menneskelige side af virksomheden. Målet er at udvikle et miljø på arbejdspladsen, hvor mennesker triveis, kan lære og kan udvikle sig og kan anvende deres ressourcer, kreativitet i forhold til de udfordringer som arbejdspladsen møder.

Midlerne til at realisere dette mål - udviklingen af medarbejderne og arbejdsorganisationen - er en bred vifte af pædagogiske tiltag:

- Formaliseret lcering: formalisering og certificering:

- Uuddannelse af medarbejderne på kortere kurser (AMU-kurser)

- $\quad$ Uuddannelse af medarbejderne på længere uddannelser (industrioperatøruddannelsen)

- $\quad$ Uuddannelse af medarbejderne i forhold til fælleskrav om sikkerhed på arbejdspladsen mv.

- Non-formal leering: formaliseret men uden stats godkendte almene certificeringer:

- Sidemandsoplcring: uddannelse af medarbejderne til erhvervelse af „hard core kvalifikationerne“: de nødvendige kompetencer til at betjene de konkrete maskiner og maskinparker, der er helt særegne for denne arbejdsplads. Der gives en arbejdsplads certificering i form af „kørekort“ til den/de maskiner man må betjene.

- Tilbagevendende internatkurser for det samlede personale, ledet af eksterne konsulenter, hvor medarbejderne analyserer egen 
arbejdsplads og lægger konkrete planer for udvikling af arbejdspladsen, rammer for produktionsgrupperne osv.

- Udvikling af arbejdspladsen som et frugtbart læringsmiljø. Informal læring: læring der finder sted som en integreret del af arbejdet, læring er ikke udskilt som en selvstændig proces.

- $\quad$ Team-læring, læring i produktionsgrupperne: læring om planlægning, samarbejde, kommunikation mv. i forbindelse med varetagelsen af det komplekse arbejde i produktionsgrupperne

- Læring gennem refleksion. Der er på arbejdspladsen skabt særlige muligheder for refleksion på møder og i mini-kontorer

- Læring gennem erfaringslæring og problemløsning i det daglige arbejde. Gennem organiseringen i produktionsgrupper møder medarbejderne et bredt spektrum af arbejdsmæssige krav og udfordringer i deres arbejde.

- Læring gennem videndeling. Det formuleres fra ledelsesside, at arbejdspladsen hele tiden - på grund af teknologiudviklingen der kræver ny viden mht. at betjene maskiner og på grund af behovet for den løbende udvikling af arbejdsorganiseringen - har et stort behov for både at få tilført viden udefra, og for at få delt den viden, der eksisterer i virksomheden. Arbejdspladsen søger på mange måder at støtte sådanne vidensdelingsprocesser.

- Læring gennem inddragelse af medarbejderne i udviklingsprojekter. På den ene side besidder medarbejderne omfattende ressourcer i forhold til udviklingsarbejder, i form af idéer og erfaringer, på den anden side erhverver medarbejderne en betydelig indsigt i virksomheden og dens udviklingsprocesser gennem deltagelsen i udviklingsprocesser i arbejdet.

\section{Arbejdspladsen}

NKT-cables Asnæs er en fabrik, der er en del af en større concern, NKTHolding der har fabrikker 9 steder I Europa. NKT fremstiller kabler. Virksomheden er den eneste af sin art i Danmark.

I dag udvikler, producerer og sælger virksomheden en lang række forskellige kabler, bl.a. kommunikations og datakabler og tilbehør. NKTafdelingen i Asnæs producerer med overskud.

Virksomheden har ca. 450 medarbejdere. Medarbejderne i produktionen er dels uddannede maskinoperatører og dels ufaglærte, der er oplært i virksomheden.

Medarbejderne bliver generelt længe i virksomheden. Der arbejdes i produktionen i tre holds skift.

For virksomheden har det i den hårde globale konkurrence været nødvendigt hele tiden at have den mest moderne og avancerede maskinpark til produktionen. Dette forhold bestemmer i høj grad medarbejdernes arbejde i produktionen. Det bliver medarbejdernes primære opgave at 
holde produktionen og hermed maskinerne i gang på den korrekte og effektive måde. Arbejdet for medarbejderne i produktionen består i konstant at forsyne med de nødvendige råvarer og overvåge og kontrollere at produktionen - der foregår i komplekse maskinparker - forløber regelmæssigt og korrekt. Med dette mønster kan virksomheden karakteriseres som proces-industri.

Pres for og ledelse af udviklingen i virksomheden

Et væsentligt incitament til udvikling af virksomheden har været det ydre pres på NKT. Dette ydre pres udspringer af tre forhold: Internationalisering, konkurrence og krav til kvalitet.

I den planlagte og systematiske udvikling af virksomheden er der tre felter der altid har været set i sammenhæng:

- Køb af teknik (maskiner, maskinpark), teknikudvikling

- Medarbejderuddannelse/-udvikling, kompetenceudvikling af medarbejderne

- Udvikling af arbejdsorganiseringen

Produktionsgrupper er omdrejningspunktet i virksomhedens arbejdsorganisering. Produktionsgrupperne har en ret høj grad af autonomi, idet de har betydelige beføjelser og stor indflydelse på eget arbejde. Produktionsgrupperne fremstår i dag som et reflekteret svar på udfordringerne på det globale marked, outsoursing-trusler osv.

Ledelsesfilosofi om den menneskelige side af arbejdet: Work smarter not harder

Både fra ledelses- og tillidsmandsside gives der udtryk for, at fabriksarbejde er hårdt arbejde. Arbejdets organisering ses som et middel til at skabe et arbejdsliv med udfordringer og goder i form af medindflydelse, medansvar, personlig udvikling og et godt arbejdsklima. Lykkes det at skabe et godt psykisk arbejdsmiljø, hvor medarbejderne trives og udvikler sig, vil dette også bevirke at deres produktivitet - og kvaliteten - er høj. Arbejdsorganisering og medarbejderudvikling må således ses i sammenhæng med rekruttering og fastholdelse af personale, og kvalitet og effektivitet i virksomhedens produktivitet.

Arbejdsorganisering og videnstung produktion: team-organiseret arbejde NKT ændrede i starten af 1990'erne sin arbejdsorganisering, fra en arbejdsorganisering efter princippet „én mand én maskine“ til „en gruppe af medarbejdere, en gruppe af maskiner, en gruppe af produkter“.

Virksomheden investerer løbende i og udvikler den tekniske side af virksomheden. Samtidig og sideløbende skal den menneskelige og sociale side af virksomheden udvikles. Uden den nødvendige viden om, hvordan maskinparkerne skal betjenes, er dem avanceret teknologi ikke meget 
værd. Den menneskelige side - som der i denne case fokuseres på handler om medarbejderudvikling og arbejdsorganisering.

Hermed bliver kompetenceudvikling af medarbejderne og lering i arbejdet fundamental for virksomheden. Den løbende udvikling af teknologi betyder, at jobbene og arbejdsfunktionerne i produktionen bliver videntunge, og løbende videndeling - der her ses som én form for læring - mellem medarbejderne indbyrdes og medarbejdere og ledelse, er en nødvendighed for virksomhedens effektivitet.

Hver produktionsgruppe varetager dermed den samlede produktionen af et kabel, fra råvarerne sættes til maskinen, til kablet kan afleveres til lageret. Hertil kommer, at det er et mål for hver produktionsgruppe, at alle medlemmer kan varetage alle de funktioner/betjene alle de maskiner, der ligger inden for gruppens område. Dette stiller store krav til den viden der skal eksistere i produktionsgruppen.

Produktionsgruppernes område for formel bemyndigelse i dag er følgende:

- Detalje planlægningen af arbejdet.

- Arbejdstid, ferie- og fridage.

- Udførelsen og kontrollen af arbejdet.

- Kompetenceudvikling. Produktionsgruppen står selv for del af kompetenceudviklingen hos medarbejderne der drejer sig om oplæringen ved maskinerne. Ud fra det „kørekort system“ der arbejdes med (omtales senere) sørger gruppen selv for at personer der ønsker oplæring kommer til at betjene de nødvendige maskiner og funktioner og med den nødvendige støtte fra en erfaren medarbejder i sidemandsoplæringen. Gruppen fastlægger den job-rotation der er nødvendig i relation til oplæringen. (Jobrotation er ikke nødvendig for at hindre $\mathrm{EGA}^{3}$, idet der er moderne løfteanordninger til tunge løft, mv.)

- Koordination med andre grupper og funktioner. Gruppens arbejdsfunktioner skal koordineres med andre funktioner i virksomheden, f.eks. lageret. Der afholdes faste møder hvorigennem denne koordination gennemføres. Medarbejderne fra de respektive produktionsgrupper skiftes til at være koordinator og indgå i en fælles koordinationsgruppe.

- Refleksion i gruppen. Gruppen arbejder fast med at omsætte fælles vedtagne overordnede principper for virksomheden til konkrete handlinger i hverdagen. Der følges løbende op på dette gennem et punkt på dagsordenen i et fast ugentligt møde. Der gennemføres også møder, hvor aktuelle problemer i gruppen tages op med muligheder for læring i forbindelse med disse problemløsningsprocesser. 
Alle disse områder rummer udfordringer og dispositionsfrihed for medarbejderne, og hermed et bredt spektrum af incitamenter for læring i arbejdet.

Strategi/metode: hvad gør man?

Strategien er sammensat, og kan siges at udgøres af følgende elementer:

- Udvikling af arbejdspladsen til et effektivt læringsmiljø i det daglige arbejde:

- Tteamlæring i produktionsgrupperne

- Sstøtte til refleksionsprocesser og videndelingsprocesser

- Anvendelse af eksterne uddannelsestilbud

- Anvendelse af intern oplæring: sidemandsoplæring

- Kompetenceafklaring og-validering

- Anvendelse af internatkurser for den samlede medarbejdergruppe

- Medarbejderinvolvering i udviklingsaktiviteter og i det daglige arbejde

- Follow up på udviklingsaktiviteter og planer

- Særlige roller til at stimulere og følge op på læreprocesser

- Integration af læring og virksomhedens samlede udviklingsstrategi

Udvikling af arbejdspladsen til et effektivt læringsmiljø: teamlæring i produktionsgrupperne

Arbejdet er organiseret i produktionsgrupper. Hver produktionsgruppe varetager et bredt arbejdsfelt, der bl.a. indeholder ansvar for sidemandsoplæring mv. Det brede spektrum af arbejdsopgaver giver mulighed for mange udfordringer, variation i arbejdet og et betydeligt friheds- og ansvarsområde, der fremmer læring. Arbejdet i produktionsgrupper rummer muligheder for fælles problemløsning og skabelse og udveksling af erfaringer og viden.

Arbejdet i produktionsgrupperne giver også mulighed for at lære en række sociale kompetencer, kommunikationskompetencer, samarbejdskompetencer mv., der er nødvendige kompetencer for at arbejde i teams.

Udvikling af arbejdspladsen til et effektivt læringsmiljø: støtte til refleksionsprocesser og videndelingsprocesser

Refleksionsprocesser og videndelingsprocesser foregår især på forskellige typer af møder. Der er nu fysisk installeret en række små kontorer ude i produktionen, med skrivebord og computer, hvor medarbejderne i arbejdstiden kan gå ind og tale om deres planlægning, samarbejde, organisering af arbejdet, opfølgning på beslutninger mv. Der er tale om refleksionsaktiviteter i fysisk etablerede refleksionsrum, og disse aktiviteter ses som en del af arbejdet, og indgår i den samlede arbejdsplanlægning. Refleksionsprocesser er blevet en del af arbejdsprocesserne. 
Ligeledes er der institutionaliseret en række af forskellige møder i arbejdet, der danner rammen om videndeling der er væsentlig for arbejdsudøvelsen. I disse møder, der foregår dagligt eller ugentligt, tager produktionsgrupperne bl.a. målsætninger op fra internatkurset (det årligt tilbagevendende), dvs. der er en løbende opfølgning på det man har aftalt. Læring finder i høj grad sted gennem follow up af planer for virksomhedens udvikling.

Anvendelse af eksterne uddannelsestilbud

Eksterne uddannelsestilbud anvendes med flere formål. Et formål er, at der skal skabes en fælles grundviden og kvalifikationer, der skal være ens for alle, f.eks. viden om sikkerhed i arbejdet, i forbindelse med betjening af maskinerne.

Eksterne uddannelsestilbud anvendes også med henblik på at udvikle brede basiskompetencer hos medarbejderne, der vurderes som et værdifuldt og hensigtsmæssigt grundlag for udviklingen af de særlige kompetencer der skal til for at betjene maskinparken. Disse særlige tekniske kompetencer er der kun brug for på denne ene arbejdsplads i Danmark. Der er her både tale om tekniske kompetencer, som f.eks. i industrioperatøruddannelsen, og de bløde kompetencer omkring samarbejde mv. der bl.a. er indeholdt i AMU-kurser. Der afholdes også kurser på virksomheden til udvikling af litteracy kompetencer for medarbejderne, bl.a. i dansk og fremmedsprog.

Virksomheden har en uddannelsespolitik, hvor der hele tiden er ansat en lidt større arbejdsstyrke end den der er nødvendig for at drive produktionen, således at der er en „buffer“ af overskydende arbejdskraft der gør det muligt at tage et antal medarbejdere ud til uddannelse uden for virksomheden. I denne politik indgår også, at medarbejdere helst udsendes parvis eller i mindre grupper, således at man lærer sammen. Når medarbejderne vender tilbage til virksomheden forventes det at de indgår i videndeling med andre medarbejdere, bl.a. ved at få ansvar for opgaver, projekter mv.

\section{Sidemandsoplæring}

Gennem sidemandsoplæring udvikles medarbejdernes hard core kompetencer, de specifikke kompetencer der skal til for at betjene de forskellige maskiner. Ansvaret for sidemandsoplæringen ligger i produktionsgrupperne. Sidemandsoplæringen er formaliseret på den måde, at der følges op på, om medarbejderen har erhvervet de nødvendige kompetencer for at kunne betjene maskinen.

Medarbejderen skal op til en „eksamen“, og han/hun får som „eksamensbevis“ et kørekort til maskinen. Det er et mål for medarbejderne at de skal have et vist antal kørekort, for at give virksomheden fleksibilitet ved betjeningen af maskinparken. Kørekortene er integreret med en øko- 
nomiordning, således at et vist antal kørekort giver en lønbonus, altså forhøjelse af grundlønnen.

\section{Kompetenceafklaring og -validering}

Det teknisk-faglige kompetencer er fastlagt som de kompetencer der skal til for at betjene en bestemt maskinpark, og den formelle validering ligger i det kørekort den enkelte medarbejder får som formel godkendelse, dvs. som bevis på sin realkompetence. Virksomhedens ledelse a jour fører hele tiden en liste over samtlige kørekort der er tildelt den samlede gruppe af medarbejdere.

Anvendelse af internatkurser for den samlede medarbejdergruppe

Der er skabt en tradition for at alle virksomhedens medarbejder ca. hvert andet år deltager i et internat arrangement, ledet af eksterne konsulenter, hvor medarbejdere og ledelse kollektivt dels vurderer, hvordan samarbejde og organisation fungerer, og dels skaber rammer for produktionsgruppernes virke, såkaldte „grundlove“ for produktionsgrupperne. Gennem en årrække er produktionsgruppernes virkefelt og ansvarsområde stadig blevet udvidet.

Medarbejderne inddrages således i fastlæggelsen og udviklingen af rammerne for eget arbejde. Man kan sige at arbejdspladsen har formaliseret et fælles refleksionsrum for struktur og arbejdsprocesser på arbejdspladsen. Gennem disse aktiviteter får medarbejderne mulighed for at få indblik i arbejdspladsen som et hele, dvs. overskride de erfaringer de har der er begrænset til mere afgrænsede dele af arbejdspladsen, f.eks. deres egen produktionsgruppe.

Medarbejderinvolvering i udviklingsaktiviteter og i det daglige arbejde

Der er en omfattende medarbejderinddragelse i udviklingsarbejder på arbejdspladsen. Inddragelsen i udviklingsarbejder giver muligheder for læring gennem erfaring med udvikling af nye arbejdsmåder - f.eks. lean production. Medarbejdernes erfaringer og ressourcer anses for vigtige for videndeling og udvikling af virksomheden. Medarbejderinvolvering eller participation finder således sted på mange niveauer i virksomheden: i det daglige arbejde gennem produktionsgruppernes planlægningsaktiviteter, gennem møde- og refleksionsvirksomhed, og gennem medarbejderinddragelsen i udviklingsarbejder

Follow up på udviklingsaktiviteter og planer

Den uddannelsesansvarlige på virksomheden giver udtryk for, at det ikke er så svært at formulere udviklingsplaner og initiativer, men der skal gøres en særlig indsats for at vedligeholde udviklingsaktiviteter og følge op på den. Follow up er alfa og omega for virksomheden. Follow up sikres i den struktur der er etableret for møder og refleksionsforløb, og de sikres 
ved nogle scrlige institutionaliserede roller, som uddannelseslederen og fællestillidsrepræsentanten har.

Follow up er et element i en læreproces: det giver mulighed for viden og indsigt i, hvilke konsekvenser forskellige planer, initiativer og implementeringer har givet anledning til, hvilke afvigelser der måtte foreligge i forhold til formulerede mål, hvilke sammenhænge der kan foreligge, og hvilke korrektioner og handlinger der må iværksættes for at fastholde målrealiseringen.

Særlige roller til at stimulere og følge op på læreprocesser

Den uddannelsesansvarlige og fællestillidsrepræsentanten har mulighed for at rejse spørgsmål vedr. udviklingsprocesser og udviklingstiltag, og bringe disse ind på de respektive møders dagsorden. Hermed bidrager disse rollefunktioner til at være dagsordenssættende, men ikke til at bestemme løsningen på de rejste problemer.

Integration af læring og virksomhedens samlede udviklingsstrategi

Hvis et enkelt punkt skal udvælges som adelsmærket for virksomhedens læringsstrategi må det være dette, integration. Integration finder - som vist ovenfor - sted på mange planer:

- En overordnet udviklingsstrategi er formuleret, bl.a. på internatarrangementerne, med medarbejderindflydelse. Enkeltinitiativer, formel uddannelse mv. ses i sammenhæng med den overordnede strategi

- Sidemandsoplæring, realkompetencevurdering og -certificering og lønniveau er integrerede størrelser

- Integration finder sted i den omfattende videndeling der finder sted, og som er støttet af en fysisk og organisatorisk struktur for møder og refleksion

- Refleksionsprocesser og daglige arbejdsprocesser indgår i en samlet planlægning og integreret arbejdsorganisering

- Integration af medarbejdernes erfaringer, ressourcer og ideer finder sted i produktionsgrupper, møde- og refleksionsaktiviteter og i den omfattende medarbejderinvolvering, medarbejderparticipation, der kendetegner virksomheden.

\section{Resultater og effekter}

Det vurderes at det er lykkedes at skabe en struktur, hvor en betydelig vidensdeling finder sted i arbejdet. Det vurderes at der er skabt en åbenhedskultur, hvor medarbejderne er åbne for nye udviklinger i virksomheden, og for at indgå og engagere sig i disse udviklinger.

Virksomhedsledelsen peger på en meget betydelig udvikling og forbedring i virksomhedens samlede produktion og økonomi, og tilskriver en 
væsentlig del af denne fremgang til den kompetenceudvikling og videndeling der løbende finder sted i virksomheden. Mottoet er: work smarter not harder. Vejen hertil går gennem udvikling af virksomheden som en frugtbar læringsarena, og inddragelse af medarbejderne i denne udvikling.

Det fremgår at effekterne viser sig på følgende planer:

- Individuelt, de tekniske-faglige kompetencer

- Individuelt, mere brede kompetencer. Det drejer sig om bl.a. følgende kompetencer:

- $\quad$ sociale kompetencer, kompetencer der er nødvendige for at arbejde i grupper

- $\quad$ kompetencer der drejer sig om at kunne se helheden og tage ansvar for helheden, for mere end den enkeltes afgrænsede del i produktionen

- $\quad$ kompetencer vedr. inititativ, selvledelse mv. Er bla. nødvendig for at arbejde i produktionsgrupperne

- $\quad$ åbenhed og interesse for nyt og udviklinger på arbejdspladsen

- Organisatoriske plan. Herunder bl.a.

- en åbenhedskultur

- $\quad$ en integration af arbejde, lærings- og udviklingsprocesser

- en gunstig indflydelse på produktivitet og økonomi i virksomheden

\section{Referencer}

Andersen, V., Clematide, B. og Høyrup,S.: Arbejdspladsen som læringsmiljø. Learning Lab Denmark, Roskilde Universitetsforlag, 2004. Heri især:

Steen Høyrup: Læringsformer, refleksionsprocesser og læringsrum i arbejdslivet, p. 73-98.

Steen Høyrup og Pernille Bottrup: Bæredygtighed på arbejdspladsen. Refleksion og læring i arbejdet. LO, april 2004

Steen Høyrup: Reflection as a core process in organisational learning.
Journal of Workplace Learning, Vol. 16, No.8, 2004, p. 442-454

Høyrup, S. og Kjærgaard. C.: Nye læringsformer i arbejdslivet. 2. delrapport. Virksomhederne: Læring og udvikling i arbejdet. Erfaringer med det udviklende arbejde. Herunder: kap. 2: Cases. Kelsen A/S, p. 25-37. Knud Illeris \& samarbejdspartnere: Læring i arbejdslivet. Learning Lab Denmark, Roskilde Universitets forlag, 2004 


\section{Case 3. Medarbejderuddannelse gennem medarbejder- dialog}

En deltagelsesskabende metode til kompetenceafklaring og

uddannelsesplanlcegning på arbejdspladsen.

Case af Maija Vahamaki. Redigeret af Steen Høyrup

\section{Baggrund. Problem og sigte}

Casen er en beskrivelse af et kompetenceudviklingsprojekt, der i 1999 blev udført ved et lille trykkeri i Finland, med fokus på de virkninger, som projektet fik for produktionspersonalet på arbejdspladsen.

Udgangspunktet for kompetenceudviklingsprojektet var forandringer i arbejdet og de hertil knyttede problemer med at etablere uddannelse/læring, der modsvarede behovene for nye kompetencer.

I kortlægningen af effekterne af projektet, dvs. den betydning som de udviklede kompetencer og læring har, er der både en kort og en lang tidshorisont. Det er her tanken, at selv om projektets kortsigtede effekt var en betydelig fremgang for virksomheden, så viser de vigtigste effekter sig over længere tid, når det kortlægges, hvordan det der blev lært bliver integreret i praksis og får konsekvenser af forskellig art for arbejdspladsen. Dette blev belyst gennem en opfølgning i fire år efter selve projektets afslutning.

Kompetenceudviklingsprojektet evalueres på to måder: (1) Hvor vellykket var projektet rent funktionelt, vurderet ud fra virksomhedens perspektiv? (2) En kritisk undersøgelse af de elementer der udgjorde de største udfordringer.

De forandringer, som projektet giver anledning til, vurderes altså ud fra langtidsvirkninger. I denne sammenhæng belyses læring både ud fra et individuelt og et kollektivt/organisatorisk perspektiv. Sidstnævnte perspektiv er arbejdsfællesskabets perspektiv.

De læreprocesser der fandt sted i arbejdsfællesskabet (kollektive læreprocesser) indbefatter læring mod selvstyring og en diskuterende arbejdsindstilling. De enkelte medarbejderes faglige (yrkesmæssige) læreprocesser og den kollektive/organisatoriske læring, ses som processer der støtter og overlapper hinanden.

Artiklen belyser således tre hovedspørgsmål:

1. Hvordan medarbejderne i trykkeriet lærer sig sit job

2. Hvordan denne læring influeres af, og må forstås i sammenhæng med, udviklingen af en fællesskabskultur (gemenskapsanda)

3. Hvilken betydning dette har for læring i arbejdet 


\section{Arbejdspladsen}

Arbejdspladsen er et lille trykkeri, altså en del af den grafiske industri. Som følge af digitaliseringen overgår produktionsteknikken til digital teknik, der ændrer arbejdet radikalt og stiller krav om nye kompetencer hos trykkeriarbejderne. Den lille virksomhed skal håndtere den udfordring at give medarbejderne nye kvalifikationer, samtidig med at det er praktisk svært (at undvære personale) og dyrt at dygtiggøre personalet ved at sende medarbejderne på eksterne kurser. Og udbuddet af uddannelse fra kursusudbydere svarer tit ikke til uddannelsesefterspørgslen fra virksomhedens side.

Virksomheden er grundlagt i 1915, og er placeret i en provins, Egentliga Finland. Virksomheden er et aktieselskab. Væsentligste arbejdsområder er fremstilling af trykkeriprodukter og forlagsvirksomhed. Der er i perioden 1999-2004 ansat 100-124 personer, heraf 50 i trykkeri produktionen. Konjunkturændringer inden for branchen, fluktueringer i virksomhedens eksport og økonomi, ændret teknologi mv. har givet negative gennemslag i personalets trivsel og motivation. Virksomheden har satset på personaleudvikling, der dog er blevet begrænset af vanskelige økonomiske perioder. Trods disse vanskelige vilkår udtaler virksomhedens direktør, at personalet har haft en positiv indstilling til projektet (kompetenceudviklingsprojektet), og at klimaet (andan) i virksomheden er god.

Virksomhedens ledelse tog i 1999 initiativ til en organisationsforandring, hvorefter personalet blev organiseret i teams med en øget selvstyring. I en ph.d.-afhandling beskrives teamenes udvikling mod større selvstyring som en fællesskabsbaseret læreproces der delvis overlapper kompetenceudviklingen hos de enkelte individer.

Virksomhedsledelsen opfattes som demokratisk, og en vigtig baggrund for læringen i arbejdet har været, at teamene er blevet tilbudt som en struktur, hvis udformning de ansatte selv har haft indflydelse på. Artiklen beskriver, hvordan teammedlemmerne i fællesskab bliver dygtige til at udvikle deres arbejds team og tog imod den frihed som selvstyringen indebar. Dette ses som udtryk for organisatorisk læring.

De teams, der udgør kernen i arbejdspladsens organisering, beskrives ud fra: teamets opgave, struktur, grad af modenhed og grad af indre heterogenitet. Der er i produktionen 6 teams på 6-10 personer. Teamene modsvarer momenter i produktionen, f.eks. team for forberedelse (prepress), trykning og efterbehandling. Det efterstræbes at undgå kliker af bestemte erhvervsgrupper.

Opgave: teamet udfører arbejdspladsens grundlæggende virksomhed, at fremstille tryksager. Der skal produceres af høj kvalitet, og produktionen skal forløbe smidigt. Arbejdsopgaverne er på den ene side ret rutineprægede. På den anden side er der krav om ny teknisk viden i forbindelse med udvikling af teknologien. De stadig ændrede kompetencekrav er en del af profilen. Der er krav om hele tiden at lære nyt, hvilket for nogle medarbejdere opleves som belastende. 
Struktur: teamets hierarkiske struktur er lav. Målet er at udvikle team med selvstyring og ligestilling blandt medemmerne. Der er således ikke en formand eller teamleder, men en rolle som kontaktperson går på skift. Alle 50 medarbejdere i produktionen refererer til produktionschefen. Teamet er sig bevidst, at de har ansvar for produktionen som helhed. Arbejdsopgaver fordeles efter medarbejdernes kompetence, og efter de krav, der udgår fra maskinerne, men med udviklingsprojektets forløb kan ses en tendens mod brede kompetence krav (mångkompetens).

Modenhed (i gruppeudvikling). Teamene var dannet i 1999. Ved projektets start var de optaget af at lære sig den selvstyring, de havde fået mulighed for. En rimelig grad af selvstyring havde grupperne først udviklet efter 2-3 år. Teamene fulgtes ikke helt ad i udviklingen, nogle udviklede sig hurtigere end andre.

Indre heterogenitet. Graden af indre afhængighed og samarbejde, varierer i teamene. I nogle teams er der overvejende tale om en individuel arbejdspræstation, i andre er samarbejde og fysisk nærvær nødvendigt. Der hvor arbejdet udføres i fysisk nærhed og samarbejde udvikles en stærkere følelse af tilhørsforhold til gruppen

Strategi og metode: Hvad gjorde man?

Projektet indeholder en undersøgelse at et pilotprojekt, hvor et bestemt system afprøves: „Kvalitetssystem för personalutveckling“.

Vigtige karakteristika ved dette system er følgende:

- Det indeholder en hensigtsmæssig metode til at gennemføre kompetencekortlægninger

- Det er et eksakt og systematisk værktøj til målrette uddannelse

- Det har et bredt anvendelsesområde mht. personaleanliggender (løn, uddannelse, etc.)

- Det kan opdateres internt i virksomheden

- Kortlægning af kompetencer foretages ikke af en ekstern person, men af personalet selv på arbejdspladsen. Dvs. der er participation i kompetence kortlægningen.

- De ansatte bidrager til kompetence kortlægningen gennem et forløb af diskussionsmøder. Der anvendes betegnelser som ,intervention“, aktionsforskning og model for demokratisk dialog, jfr. Bjørn Gustavson 2001). Det er dog ikke forskeren der styrer samtalen. Forskeren er facilitator på dialogmøderne.

Dette projekt - afklaring af virksomhedens kompetencesituation, varer i sin helhed 9 måneder, og gennemføres i trykkeriet. 
Planlægningsfasen

Det fremhæves at udviklingsvirksomhed på en arbejdsplads forudsætter engagement fra ledelsens side i projektet. På et overordnet og et konkret plan. Overordnet for at medarbejderne kan have tillid til projektet. I særdeleshed $i$ et kompetenceudviklingsprojekt er ledelsens engagement vigtig, fordi et omdrejningspunkt i projektet er sammenhængen mellem organisationens mål og arbejdsprofilen for hver enkelt af de ansatte, og her er diskussion og samarbejde mellem ledelse og medarbejdere fundamental. Der skabes i denne kontakt en videndeling mellem ledelse og medarbejder, på to områder: de mål der stilles op af ledelsen og forudsætningerne for at udføre arbejdet, set fra de ansattes perspektiv.

Målet for projektet var at udarbejde en uddannelsesplan og få de ansatte til at forpligte sig til at gennemføre den.

På et indledende møde mellem ledelsesrepræsentanter, medarbejderrepræsentant og forskeren/konsulenten træffes aftale om: kompetenceudviklingsprojektets sigte og mål, fremgangsmåde, herunder hvor stor en gruppe af de ansatte der skal deltage, tidsplan og nødvendige ressourcer.

Planlægningen forløber fra marts til december 1999.

Deltagelse: hele produktionsgruppen

Mål: en god udviklingsplan skal udarbejdes for de følgende to år. Personalets faglige kompetencer (yrkesskicklighet) skal udvikles og opdateres, så de modsvarer de nye tekniske krav.

Sigtet er ved hjælp af en kompetencekortlægning at identificere de mest aktuelle kompetencebehov og at foretage en prioritering af behovene på uddannelsesområdet.

\section{Information og fordeling af arbejdsudgifter}

Det besluttes at arbejde med kompetence kort, med udgangspunkt i teamene, og ikke på grundlag af arbejdsopgaverne. Dette er begrundet $\mathrm{i}$, at et af målene er at skabe fleksibilitet i arbejdsprofilerne. Det betyder at der i projektet kan lægges vægt på at udvikle helhedskompetence i arbejdsfællesskabet frem for at fokusere på kompetenceudvikling af det enkelte individ.

Hver enkelt medarbejder får mulighed for at deltage i udarbejdelsen af kompetenceprofilen for hans/hendes eget team.

Fremgangsmåden er at virksomhedens trykkeri ingeniør udarbejder overordnede skabeloner for teamenes kompetenceprofiler. Herefter supplerer medarbejderne med at tilføje mere eller mindre detaljerede kompetencekrav, som de vurderer hører til teamets arbejde. Spørgeskemaer (enkäter) teamenes arbejdsopgaver sendes til medarbejderne, der får en uge til at svare. Spørgeskemasvarene bearbejdes af forsker og ingeniør, således at der udarbejdes en kompetenceprofil for hvert team. Efterfølgende holdes diskussionsmøder i teamene, der igen supplerer materialet. 
Udformning af team-profiler: team overskridende diskussion.

På et efterfølgende møde, hvor repræsentanter for hvert team deltager, gennemarbejdes de syv kompetenceprofiler for hvert af de 7 team. Produktionsledelsen deltager i mødet. Behøver den formulerede kompetenceprofil at blive udvidet, eller er noget overflødigt? Man diskuterede også de mål, der skulle stilles op for kompetencerne i teamet: målene skulle være realistiske men samtidig tage hensyn til fremtidige kompetencebehov.

- Ledelsen får til opgave i kompetenceprofilerne at definere detaljerede mål for det fremtidige kompetenceniveau.

- Deltagerne opfordres til at formulere erfaringer fra situationer hvor:

- Det er den ansatte der bedst kender til praksis og kompetence der er en forudsætning for at udføre arbejdet

- Kendskab til andres arbejdsopgaver og kunnen hæves til et helhedsperspektiv og får betydning for de enkeltes arbejdsindsat.

Skabelsen af dette helhedsperspektiv, der angiver sammenhæng og indbyrdes afhængighed i arbejdsprocessen, er et afgørende trin i kompetenceafklaringsfremgangsmåden. Det er fint at de enkelte medarbejdere tager sig af deres eget job, men det er også vigtigt at de medtænker det andre arbejder med, fordi produktionsprocessen på et trykkeri udgør en helhed hvor de første arbejdsprocesser påvirker de efterfølgende. Hvordan påvirker de tidlige arbejdsprocesser de efterfølgende?

Udformning af profilerne

Produktionschefen formulerede mål for de enkelte teams kompetenceprofiler. Målene formuleres mht. følgende:

- Kkompetenceniveau (på en skala 0-4: jeg behersker mit arbejde helt jeg behersker slet ikke mit arbejde)

- Hhvor mange medarbejdere i et team der skal beherske en bestemt opgave på et bestemt niveau

Det kan f.eks. tænkes at et team har brug for en medarbejder på ekspertniveau, nogle stykker på mellemniveau, og nogle på det grundlæggende niveau.

På efterfølgende møder med medarbejdere og ledere finjusteres formuleringerne af kompetenceprofilerne.

Der udformes såkaldte kompetencekort. Kompetencekort indeholder:

- Kompetenceområderne for et team

- Teamets ambitionsniveau (mål) på hvert af de formulerede kompetenceområder

- Niveau for den eksisterende (faktiske) kompetence, på hvert af de formulerede kompetenceområder 
- Hvor mange medarbejdere i teamet, der skal have kompetencer på de respektive niveauer

Sammenkædning af personlige profiler og team-profiler

Når målprofilerne for teamene var færdige fik de enkelte medarbejdere til opgave at beskrive egen personlige kompetence, ud fra disse målprofiler som skabelon. Samtidig får de ansatte mulighed for at diskutere deres personlige udviklingsplaner med udviklingschefen. I denne fase af projektet anvendes kompetencekortlægningen som basis for en samtale mellem chef og medarbejdere. Udviklingschefen kan gå ind i diskussioner om divergenser i lederens vurdering af medarbejderens selvvurdering, altså en vurdering om over- og undervurdering af egen kompetence i selvvurderingen.

Formulering af kompetencebehov/uddannelsesbehov (kompetensluckorna), og hvordan de kan imødekommes af resp. interne og eksterne ressourcer.

Med reference til kompetencekortene, og ovenstående sammenholdelse af personlige og team-profiler, udarbejder ledelse og konsulent kompetenceudviklingsbehovet, for hvert team, dvs. de kompetencer der mangler og som skal udvikles.

Det blev beregnet, at $70 \%$ af uddannelsesbehovet kunne imødekommes gennem coaching af personer med den ønskede ekspertise inden for arbejdspladsen. $30 \%$ af uddannelsen måtte der hentes ekspertise til udefra, dvs. ekstern uddannelse.

Justering af kompetenceprofilerne og inddragelse i uddannelsesplaner Team'ene får lejlighed til at reagere på resultatet af kompetence kortlægningen:

- Viser kompetencekortene det faktiske/eksisterende kompetenceniveau, og

- Hvordan ønsker medarbejderne at uddannelserne skal gennemføres?

Det viste sig at 4 teams fandt kompetencekortene meget dækkende, medens 3 teams fandt kompetencekortene dårlige i deres fremstilling.

Følgende emner blev diskuteret:

- Eget kompetenceniveau og kompetencemål

- Egen kompetencevurdering sammenholdt med kollegers vurdering af medarbejderens selvvurdering (over- eller undervurdering?)

- Hvordan man bedst kunne afhjælpe mangel på kompetencer (kompetencebehov)

Den deltagelsesskabende metode er forbundet med en række fordele: 
- En ofte fremført kritik af kompetencekortlægninger (særlig ved selvvurderinger) er, at de kvantitative udtryk for mål ikke er sammenlignelige, fordi medarbejderne har givet dem efter skøn („,på känn“). Ved denne metode fremkommer en intern skala for kompetenceniveauer, hvor tallene blot er symboler, hvis mening bliver forhandlet og skabt fortolkning af, i teammøder. Kompetencekortet er et resultat af forhandling på arbejdspladsen, og kan ikke uden videre overføres til andre arbejdspladser.

- Proceduren bidrager til at „kompetence“ ikke behøver blive forstået som en personlig egenskab, og en bedømmelse af om en ansat er god eller dårlig. Det gør det lettere at opfatte kompetence som en størrelse der kan udvikles, og i denne udvikling kan hele teamet deltage. Kompetencekortet er en medarbejders arbejdsredskab, ikke medarbejderens personlighed.

- Ovenstående støttes af at graferne i kompetencekortlægningen viser hvordan en persons kompetenceniveau varierer på forskellige delområder af en arbejdsopgave. Der er ikke billeder af medarbejdere som generelt gode eller dårlige i deres arbejde.

- I nogen team får man øjnene op for at uddannelsesbehovene kan imødekommes ved den ekspertise, der allerede findes i teamet.

De ansatte arbejdede med formulering af egne uddannelsesplaner således at hvert team fremlagde deres egen prioriteringsliste over uddannelse, som teamet ønskede under en eller anden form i fremtiden. På dette grundlag formulerede ledelsen retningslinier for år 2000. Uddannelsesplanen fører til udarbejdelsen af et uddannelsesbudget. Arbejdsgruppen for kvalitet- og uddannelsesplanlægning justerer og godkender planen, der også godkendes af de faglige ledere. I de efterfølgende år gennemføres uddannelse i virksomheden i overensstemmelse med denne plan.

\section{Resultater og effekter}

Det vurderes:

- Hvilke iagttagelige virkninger projektet fik, bl.a. på smidighed og kvalitet i produktionen

- Hvordan udviklingsplanerne, der blev skabt af projektet, blev realiseret

Metoden der anvendes er:

- Interview af ledelse og medarbejdere

- En mindre spørgeskemaundersøgelse

- Informationer fra kvalitetsindikatorerne for virksomhedens produktion

- Gruppeinterview med medarbejdere i slutningen af 2003 
Der gennemføres to typer af analyse:

1. Projektets direkte virkninger på arbejdsmåden inden for produktionen i virksomheden. Metoden er her interview med produktionschefen.

2. Virkninger på lang sigt. Væsentligst er her de opfattelser af læring og kompetence, som de ansatte gav udtryk for, og det billede de skabte af læreprocesserne i organisationen. Herunder analyseres, hvordan læring i arbejdet, dvs. læring inden for et fællesskab, hænger sammen med udviklingen af erhvervskompetence hos de enkelte individer.

Effekter af kompetenceudviklingsprojektet

(1) Effekter som grad af realisering af projektmål.

Der var opstillet følgende mål for projektet:

1. Det skal være let at gennemføre metoden ved hjælp af virksomhedens egne ressourcer og tilpasse metoden til virksomhedens egne behov

2. Metoden skal være billig at gennemføre og må ikke kræve investeringer i nye datasystemer

3. Metoden skal bygge på de ansattes deltagelse (participation)

4. Ved hjælp af metoden skal det være muligt præcist at fastlægge kompetencebehovene inden for virksomheden, hvilket gør det lettere at placere uddannelsen præcis der hvor der er behov for den, hvilket indebærer besparelser på uddannelsesbudgettet

5. Metoden støtter kvalitetsledelsen i virksomheden

Det konkluderes, at alle målene blev imødekommet. Metoden er billig idet den anvender et almindeligt Excel-programn for kompetencekortene. Meget central i metoden er de ansattes deltagelse/participation: det er ofte de ansatte der har den bedste viden om de områder af erhvervskompetencer, hvor uddannelsesbehov findes. Det lykkes at skabe den „ånd“ af fælles skabende/kreativitet(skapande) og diskussion på lige vilkår, som var tilstræbt.

Deltagerne begyndte at se læring som en del af arbejdet.

De interne diskussioner fører også til en fælles oplevelse af, hvad der var de vigtigste uddannelsesbehov i virksomheden.

Ved arbejdet med kompetencekortene blev det tilstræbt at være præcis og undgå generaliseringer, hvilket ofte sker ved beskrivelse af kompetencebehov. Ved at beskrive de præcise behov kan man „kalde på“ præcis den undervisning de er behov for, frem for at arbejde med mere diffuse uddannelsestiltag.

Projektet kom til at støtte et igangværende kvalitetsprojekt, der førte til en certificering. 
Projektets primære mål var at give en præcis beskrivelse af „kompetence-huller“, dvs. områder hvor der manglede kompetence. Den deltagende metode viser sig at have andre positive følgevirkninger:

Inden for arbejdsorganisationen blev man bevidst om anledninger til at udvikle arbejdsmåder og muligheder for at forbedre dem medarbejderne lærte at underkaste deres arbejdsmåde en reflekterende undersøgelse man kunne diskutere kvalitetsudvikling og arbejdsproblemer i større fora end tilfældet er ved en normal arbejdsdag. Disse fora er ofte grupper der er sammensat på tværs af teamene i produktionsprocessen, således at diskussioner og information kommer ud i alle hjørner af arbejdspladsen.

Der skete en udjævning af arbejdsbyrden medarbejderne imellem i og med at flere medarbejdere fik et bredere kompetenceområde.

(2) Observerede effekter: tekniske og organisatoriske virkninger.

De tekniske virkninger er en følge af den systematiske gennemførelse af kompetencekortlægningen. De organisatoriske virkninger havde relation til arbejdspladsens interne kultur og holdningsændringer her.

Af tekniske virkninger opregnes følgende:

- Uddannelsesplanen bygger på behov der er præcist kortlagt. De vigtigste områder for læring (forestående kompetenceudvikling) der skal finde sted på arbejdspladsen er blevet prioriteret.

- Da kompetencebehovene kendes i detaljer kan man købe ekstern uddannelse eller arrangere intern uddannelse der specielt er målrettet kompetencebehovene

- Uddannelse kan tilrettelægges på grundlag af hos hvilke personer og i hvilke arbejdsområder behovene eksisterer

- En hensigtsmæssig målretning af uddannelsen medfører besparelser på uddannelsesbudgettet

- En kompetencekortlægning der er forholdsvis detaljeret virker som huskeliste for den interne uddannelse og coaching

- Ved hjælp af kortlægningen kan man afdække skjulte kompetencer (realkompetencer)

- For hver enkelt af de ansatte kan man udvikle et personligt specialkompetenceområde

- Koncernen får adgang til en ressourcebank over specialkompetencer

- Det blev erfaret, at det var lettere at motivere ansatte til at deltage i uddannelse når uddannelsesbehovene blev gjort til genstand for fælles diskussion.

- Ledelsen vurderer, at der er sket en enorm udvikling mht. en styrkelse af erhvervskompetencerne (yrkesskicklighetens område) hos medarbejderne. Virksomheden kan fungere med de nye kompetencer, som den ny teknologi fordrer.

Den øgede kompetence viser sig bl.a. i forbindelse med indikatorer for kvalitetsopfølgning: 
- Reklamationer pr. arbejdsenhed (arbetsmoment)

- Antallet af interne fejl

- Kunde reklamationer og kundetilfredshed

Først og fremmest vurderes projektet at have udviklet en uddannelsesplan, der modsvarer uddannelsesbehovet, en uddannelsesplan der er målrettet og systematisk.

Virkninger på organiseringen af arbejdet og produktkvaliteten (tekniske virkninger)

- Kompetencekortlægningen støtter kvalitetssystemet. Det er lettere at korrigere de fejl som konstateres i produktionen

- Bedre informationsstrømme mellem arbejdsområderne.

- Bedre prognoser. De fremtidige kompetencebehov erkendes i god tid

- Fleksibilitet i arbejdsprofilerne. Den enkelte kan udbrede sit kompetenceområde når det er hensigtsmæssigt i forhold til produktionsgangen

Virkninger på uddannelseskulturen og holdninger i arbejdet

- Virksomhedens målsætninger bliver klare for alle, og den enkelte medarbejder kan se hvordan han/hun i sit arbejde kan bidrage til målsætningen

- En øget åbenhed når det drejer sig om at diskutere kompetencespørgsmål. Et åbent og positivt samtaleklima

- $\quad$ Ændret holdning til uddannelse. Læring og vejledning af andre udgør en del af arbejdsprofilen for alle

- Personligt at tage ansvar for udvikling af kompetencen. Deltagelse i uddannelse for at gøre noget ved et kompetencesvælg i eget arbejdsteam.

- Teamkultur (teamanda). Teamets præstations kapacitet (prestationsförmåga) bliver genstand for fælles diskussion

- En diskuterende arbejdsmåde

- Medarbejderne begynder at se læring som en del af arbejdet

Sammenfattende fremtrceder følgende felter som de tydeligste effekter af projektet:

1. Medarbejderne tager i højere grad ansvar for udviklingen af de nødvendige kompetencer i teamet, og for deltagelse i uddannelse. Holdningerne til uddannelse bliver mere positive.

2. Et mere åbent samtaleklima

3. Udvikling af en korpsånd (teamanda)

4. Ændret holdning til læring og undervisning af andre. Tidligere blev dette betragtet som en separat foreteelse, men der var en tendens til at 
se det som en del af arbejdet. Refleksion over behov for uddannelse, blev ligeledes set som en del af arbejdet. Man kan sige at medarbejdernes opfattelse af, hvad et arbejde er, blev ændret og udvidet, således at det indbefattede læring og kompetenceudvikling og som en integreret del.

Vigtig i de konstaterede effekter er, at effekterne overskrider et individniveau, og f.eks. viser sig på gruppe-niveau, i det der her kaldes arbejdsfællesskabet. Arbejdsfællesskabet søger at lære sig - ud over udviklingen af den individuelle erhvervskompetence - nye måder at fungere på for at vedligeholde kompetencen. Man har lært sig at diskutere kompetencen som en del af arbejdet, og ikke som en personlig egenskab.

Der var ikke blot tale om intra-gruppe effekter. I projektet arbejdede man med det enkelte teams betydning for produktionen som helhed, og for at udvikle et samspil mellem de enkelte team, altså inter-gruppe ændringer. Det blev vurderet af ledelsen, at der skete en forbedring a dialogen, såvel inden for de enkelte teams, som mellem ledelsen og medarbejderne.

Deltagelse er et fremtrcedende element. Deltagelsen i projektet starter tidligt, i planlcegningsfasen og inkluderer således:

- Udformningen af kompetenceprofilerne

- Vurdering af kompetenceprofilerne

Langtidseffekter

Efter 4 år vurderer ledelsen:

- Kkompetenceafklaring er et redskab til at fremme den praktiske planlægning af kompetenceudvikling

- Ææændringer i holdninger hos medarbejder fremstår som det vigtigste resultat: medarbejderne har lært en diskuterende arbejdsmåde (arbetssätt)

Samlet vurderes effekterne at være virkninger af et komplekst samspil af flere og meget forskelligartede faktorer:

- Dde udviklede erhvervskompetencer

- Dden øgede motivation for uddannelse og arbejde

- Dde nye holdninger til arbejdet

- Dden nye arbejdsmåde, en diskuterende arbejdsform

- Dden udviklede korpsånd, og intra- og intergruppe udviklingen. 


\section{Case 4. Arbetsplatslärande - ett sätt att utveckla individer och organisationer}

Case af Lennart Svensson \& Malin Ljungzell

\section{Bakgrund/sammanhang, problem och syfte}

Intresset för arbetsplatslärande har under senare år växt allt snabbare. Arbetsplatslärande kan beteckna det mesta - alltifrån ett integrerat system för lärande till traditionell pedagogik där klassrummet flyttar ut i företaget. Arbetsplatslärande kan vara ett sätt för företagen att kortsiktigt lösa akuta kunskapsbrister eller ett sätt att organisera lärande för att långsiktigt möta kompetensbehov inom en bransch.

Att utgå från arbetsplatsen som en arena för utbildning och lärande kopplat till utveckling av verksamheten kan leda till att lärandet blir intressant, både för arbetsgivare och anställda. Arbetsplatsen blir då en naturlig lärmiljö och arbetstiden kan göras till lärtid. Deltagarna kan direkt få tillämpa kunskaper som de tillägnat sig i sin arbetsvardag och utbildningen upplevs därmed som meningsfull.

I aktuell studie anges att ambitionen vid några arbetsplatser, där man försökt kombinera formell utbildning med informellt lärande, har varit att få ett samspel mellan individuellt lärande och organisatorisk utveckling. Anledningen till att man velat få till detta samspel är att man funnit att utbildning ofta leder till att individer utvecklas, men det behöver inte samtidigt betyda att organisationen eller verksamheten förändras. En avgörande förutsättning för att en utbildning ska vara till nytta i ett företag är att det individuella och det organisatoriska lärandet förstärker varandra. Det räcker dock inte med att skicka enskilda anställda på kurs för att förändra ett arbetssätt eller en verksamhet. Det en individ lär sig på en kurs är sällan direkt tillämpbart i det egna arbetet. Förutsättningar - i form av handlingsutrymme och stöd i organisationen - saknas ofta.

I mötet mellan det informella lärandet i vardagen och den formella utbildningen skapas förutsättningen för ett reflekterat lärande. Kompetensen utvecklas från det reflekterande lärandet.

I figur 1 nedan åskådliggörs det dynamiska samspelet mellan det informella (det vardagliga lärandet) och det formella lärande (det organiserade lärandet) samt mellan den praktiska och den teoretiska kunskapen. Samma figur (figur 1) visar också hur kompetens, det vill säga, en individs förmåga att agera kunnigt, effektivt, medvetet, strategiskt och reflekterat $i$ en viss situation, innebär en förening av praktisk och teoretisk kunskap. 


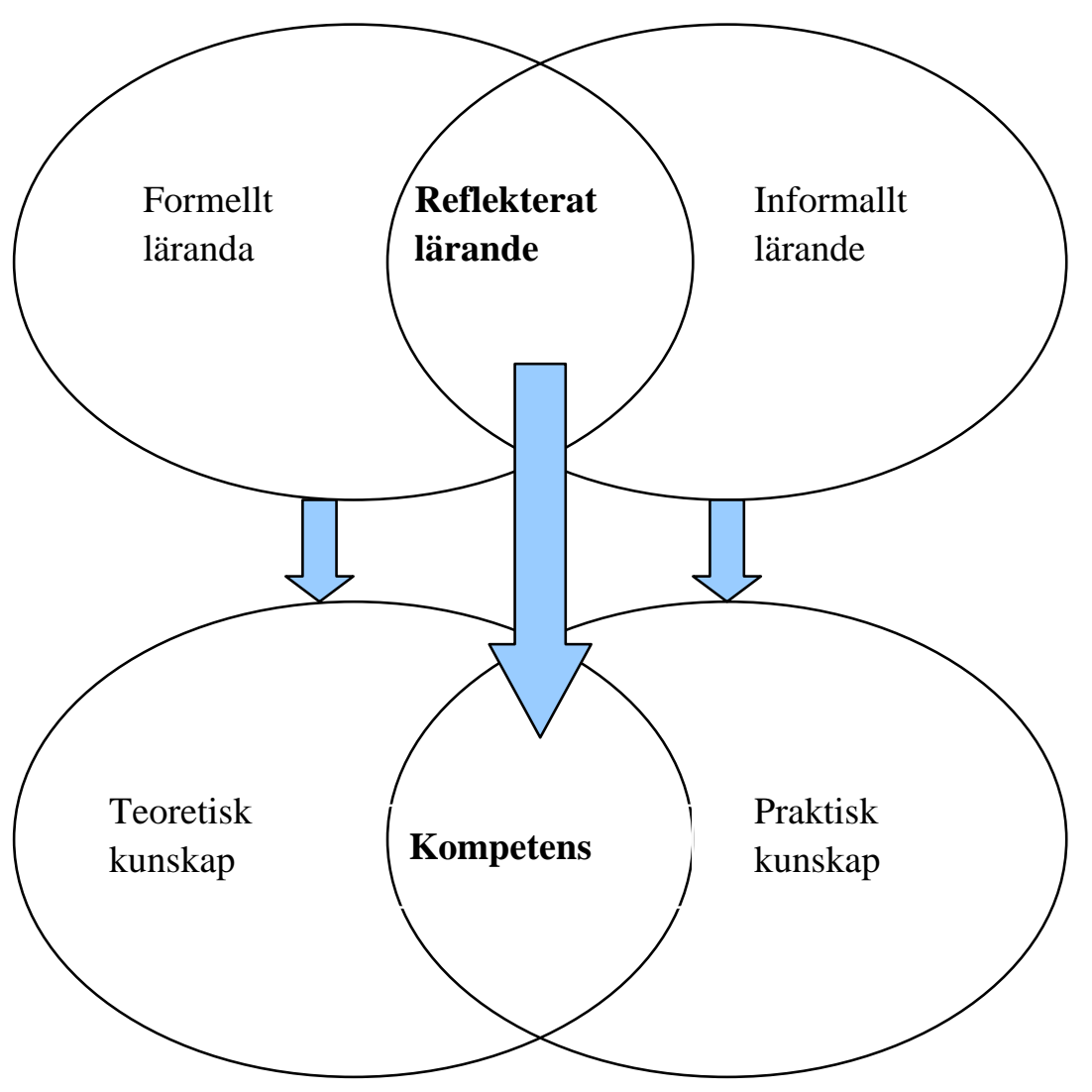

Figur 1: Reflekterat lärande leder till kompetens.

Vidare påpekas i studien att formell utbildning ofta innebär bättre möjligheter för individen att tillgodogöra sig det informella lärandet på arbetsplatsen. $\AA$ andra sidan har en person med stort praktiskt yrkeskunnande en bra grund för att ta del av en formell utbildning som anknyter till arbetsplatsens förutsättningar.

I föreliggande studie har ambitionen varit att beskriva och analysera olika stödsystem, på och runt arbetsplatsen, som är viktiga förutsättningar för att kombinera formellt och informellt lärande samt individuellt och organisatoriskt lärande. Vidare är ambitionen att diskutera handledarens betydelse och olika roller.

Syftet med denna studie är att belysa och problematisera arbetsplatslärande. Detta görs med hjälp av följande frågeställningar:

Vad menas med arbetsplatslärande? Vem har nytta av det? Vad krävs för att det ska fungera?

\section{Arbetsplatsen}

Den empiri som ligger till grund för studien utgår från lärcentrat ” Masugnen” i Lindesbergs kommun. Vid lärcentrat Masugnen driver man tillsammans med företag och organisationer olika utvecklingsprojekt med inriktning mot arbetsplatslärande samt även bristyrkesutbildning och 
Kvalificerad Yrkesutbildning (KY). I föreliggande studie har man följt och studerat ett utbildningsprogram (tillika ett pilotprojekt) för sex stycken företag inom explosivämnesindustrin. Utbildningen ägde rum under åren 2002-2003. Utöver empiri från detta utbildningsprogram har även empiri erhållits från en bristyrkesutbildning (genomförd år 2000) samt en KY-utbildning (vilken genomfördes år 2005-2006). Det innebär alltså att data har samlats in från tre olika utbildningssammanhang. Därtill bör nämnas att enkät och intervju är de två datainsamlingsinstrument som förekommit. Såväl anställda, ledningspersoner som utbildningssamordnare har intervjuats och/eller besvarat enkät.

Lärcentret Masugnen har utvecklat ett system där det finns ett minilärcentra vid deltagarnas olika arbetsplatser (Svensson \& Åberg, 2001; Svensson, Ellström \& Åberg, 2004). Företagets minilärcentra är en särskild lokal, där teknisk utrustning för distanskommunikation finns och där interaktiva studiematerial är tillgängliga. Denna typ av stödsystem som finns på arbetsplatsen kring utbildningen behöver dock kompletteras med externt stödsystem, där ett lokalt lärcentrum kan fungera som en organisatör.

Nedanstående figur (figur 2) illustrerar ett minilärcentra.

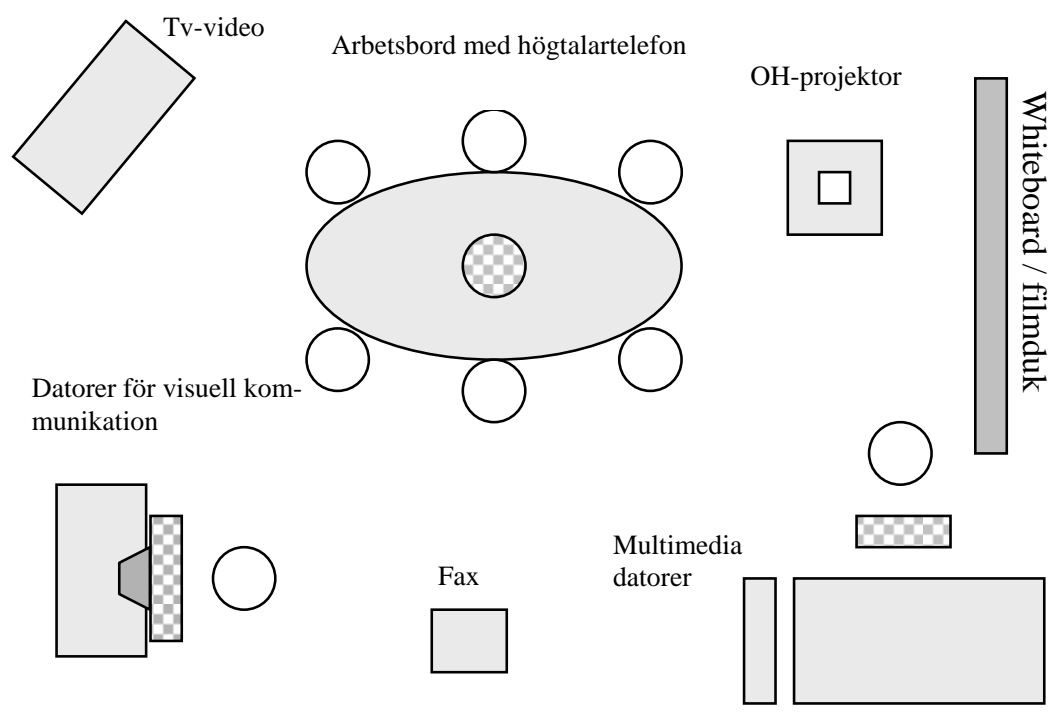

Figur 2: Modell över minilärcentra

\section{Strategi og metode. Vad gjorde man?}

I studiens inledande utbildningsprojekt var visionen att utbildningen skulle ingå som en naturlig del i företagens utvecklingsstrategi. Företagsledningen och facket involverades i utformning och planering. De anställda skulle inte skickas på kurs utan beredas möjlighet att studera i sin egen takt och på tider som passade dem själva och organisationen. Utveck- 
lingssamtal och en skriftlig samt personlig studiehandledning var viktiga verktyg i den individanpassade uppläggningen av utbildningen. Denna vision har sedermera blivit en modell för KY-utbildning (Kvalificerad Yrkesutbildning).

Ett konkret exempel på hur man gick tillväga är de projektarbeten, där företagen definierade uppgiften utifrån ett verksamhetsnära behov. De studerande fick sedan lösa detta arbetsplatsrelaterade problem som därefter var tänkt att användas på respektive företag i en utvecklingsprocess. Projektarbetet redovisades på såväl företaget som på lärcentrat. På detta sätt kunde den studerande visa att den hade tillgodogjort sig utbildningen samt att den kunde tillämpa sina kunskaper.

Arbetsplatslärande kan ge fördelar för de anställda jämfört med formell utbildning i traditionella former. Fördelar som framkommit är bland annat att utbildning som kopplas till arbetsplatsen ökar möjligheterna att koppla teori till det erfarenhetsbaserade lärandet. Den direkta nyttan (valensen) av lärandet blir därmed tydlig, vilket motiverar många anställda att delta i utbildningen. Vidare kan arbetsplatslärande vara ett stöd för de anställda som är studieovana och kortutbildade. Om utbildningen knyts till arbetsplatsen blir lärandet något vardagligt och självklart.

Arbetsplatsen ger för många en social trygghet där lärandet kan knytas till arbetsgrupper där man kan få hjälp och stöd av varandra. Detta är särskilt betydelsefullt för kortutbildade personer vilka ofta har negativa erfarenheter från sin skoltid. Arbetsplatslärande kan även ge fördelar för arbetsgivaren då utbildningen kan göras tillgänglig och anpassas efter de uttalade kompetensbehov som företaget upplever. Likaså kan utbildningen vara till praktisk nytta och genomföras på ett kostnadseffektivt sätt. Vilket är betydelsefullt för de mindre företagen, då man ofta inte har ekonomiska möjligheter att avsätta tid för aktiviteter som inte ger ett direkt avläsbart mervärde för verksamheten.

Att organisera arbetsplatslärande kräver vilja till nytänkande och stor flexibilitet hos både företag och utbildningssamordnare. Det är mycket som måste ändras, inte minst lärarrollen och de deltagandes motivation och ansvar för sitt eget lärande samt arbetsgivarens delaktighet kring innehåll och genomförande. Tre viktiga redskap, nämligen handlingsplaner, studiehandledning och handledare påpekas vara extra betydelsefulla och viktiga i samband med att få ett väl fungerade arbetsplatslärande.

Studiehandledning är en viktig komponent i arbetsplatslärande. Det är genom den som deltagarna får ett systematiskt stöd i sitt lärande. En bra studiehandledning kompenserar för den "frånvarande" läraren och det samspel mellan honom/henne och gruppen som uppstår i en traditionell klassrumsbaserad undervisningssituation. Studiehandledningen ska ge en god överblick och tydlig struktur över kursen. Den måste ständigt vidareutvecklas för att vara aktuell och innehålla stimulerande inlämningsuppgifter som underlag för dialog mellan deltagaren och läraren och mellan deltagare i olika företag. 
Efter en inledande dialog med den studerande där syfte och mål med utbildningen klargjordes samtidigt som besked om kursinnehåll och förkunskapskrav gavs så utformades en individuell handlingsplan. I planen formulerade den anställde själv sina mål med utbildningen. Innan studierna påbörjades fick kursdeltagaren också möjlighet att genomgå en preparandkurs som gav ökad förståelse för lärande i flexibla former och nödvändiga kunskaper om datoranvändning och distanskommunikation.

Handledarens roll är mycket betydelsefull och viktig. Lärandet får inte ses som någon isolerad individuell aktivitet utan som en process som kräver personligt stöd, praktisk hjälp och extern expertkompetens. Därför fick deltagarna tillgång till personliga handledare. Deltagarna träffade sin handledare regelbundet eller efter behov. I handledarens roll ingick bl.a. att fungera som mentor, förebild och personligt stöd. Vidare ingick i uppgiften att vara en instruktör, ett pedagogiskt stöd samt dokumentera deltagarnas lärande, exempelvis genom en så kallad "loggbok" där den studerande fyller i vad den gör och handledaren skriver under. Handledarens roll är som sagt mycket viktig och denna behöver ha särskild utbildning för att klara sina uppgifter. En introduktion, i form av ett interaktivt material på CD-skiva följt av en handledarutbildning, har utvecklats vid lärcentrat Masugnen. Slutligen betonas i studien också att det är viktigt att handledarna får träffa varandra för att utbyta erfarenheter och stödja varandra.

\section{Resultat och effekter}

Den utvärdering som genomförts efter att utbildningsprogrammet (pilotprojektet) inom explosivämnesindustrin avslutats visar att utbildningssatsningen i sin helhet upplevts som mycket positiv av deltagarna men att kopplingen mellan individuellt och organisatoriskt lärande har varit svår att förverkliga. De anställda upplevde nämligen inte att lärandet i det aktuella programmet var kopplat till en utveckling av verksamheten eller arbetsorganisationen. Vissa av deltagarna påpekade också att deras ökade kompetens inte lett till att de fătt mer kvalificerade arbetsuppgifter eller ökat inflytande över arbete. Härvid konstateras att utveckling tar tid och att man måste lägga stor vikt vid utbildningens koppling till organisationen.

Utvärderingen av den senare genomförda bristyrkesutbildningen för explosivämnesoperatörer visar på en rad positiva inslag, bland annat:

- Hög motivation: Deltagarna pekade på nyttan av utbildningen, delaktigheten och möjligheten att kombinera praktik och teori. Allt detta ses som viktigt för motivationen.

- Flexibilitet: Att kunna lära sig saker oberoende av tid och rum.

- Ökat intresse för utbildning och lärande: De anställda sa att de har fått ökat intresse för utbildning och beskrev hur de själva lärt sig att ta tag i problem och lära av varandra. 
Faktorer för ett framgångsrikt arbetsplatslärande - några slutsatser

Sammanfattningsvis konstateras att lärande är en komplicerad process som förutsätter dialog och handling i verkliga miljöer om det ska fungera utvecklingsinriktat. Vidare betonas att olika stödsystem är viktiga förutsättningar för att kombinera formellt och informellt lärande samt individuellt och organisatoriskt lärande. I figur 3 nedan illustreras olika delar i ett stödsystem.

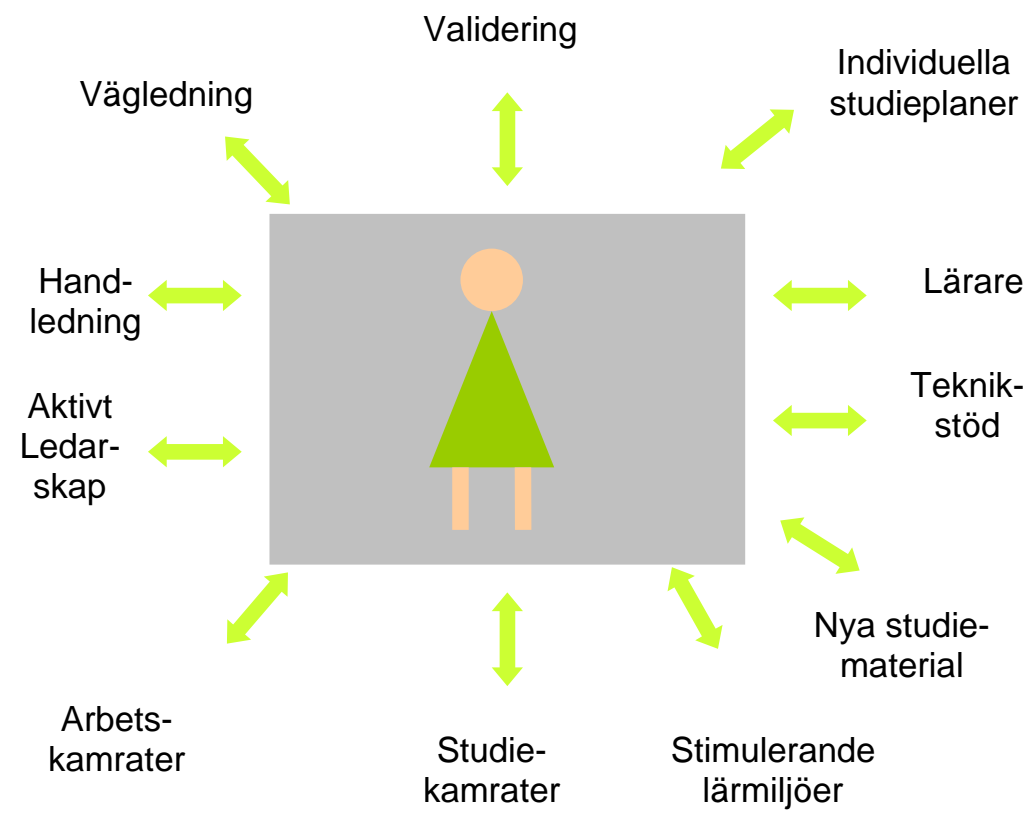

Figur 3: Ett stödsystem för arbetsplatslärande.

Figur 3 illustrerar hur arbetsplatsens och utbildningsanordnarens olika resurser används för att skapa en stödjande struktur för individen. Den studerande är inte ensam i sin studiesituation - han/hon lär tillsammans med andra. Det finns tillgång till handledare på arbetsplatsen. Studiematerial och studieplaner är anpassade till individens och arbetsplatsens förutsättningar. Det externa stödet i form av utbildningsanordnarens studievägledare och lärare är tillgängligt på tider och i former som passar deltagarna. Olika media används för kommunikation för att kunna anpassa tillgängligheten. Möten kan vara både reella (fysiska möten) och virtuella (med hjälp av teknik exempelvis telebild eller webbkamera). Lärandet sker alltså i arbetsmiljön, men med en mängd stödjande funktioner säkerställda. Vidare betonas att lärandet är "inbäddat” i ett sammanhang och att detta sammanhang måste organiseras för att en långsiktig lärprocess ska komma till stånd.

Sammantaget innehåller modellen som Lärcentrum Masugnen utvecklat för att nå ett framgångsrikt arbetsplatslärande följande viktiga inslag: 
- Möjligheten att utgå från ett erfarenhetsbaserat lärande. Det som särskilt tilltalat deltagarna är möjligheten att studera på arbetstid och i en miljö som de känner sig hemma i. Självförtroendet har växt och lusten att lära har ökat.

- Den individuella uppläggningen av utbildningen. Utvärderingarna visar att studieformen upp-levts positiv därför att deltagarna kunnat läsa i sin egen takt och att de inte varit styrda av en lärare. Utbildningen är inte skollik, utan den bygger i stället på egen aktivitet, eget ansvar och samarbete i studiegrupper.

- Tillgängligheten till ändamålsenlig teknisk utrustning på arbetsplatserna. E-learning innebär nya möjligheter - att kunna pröva på egen hand och i egen takt, att kommunicera med deltagare på distans, att snabbt få hjälp av en lärare osv. I KY-utbildningen får även de studerande låna en bärbar dator, vilket öka deras flexibilitet. De kan studera var, när och hur det passar dem själva.

- Utveckling av interaktivt studiematerial som stöd för studier i flexibla former.

I studien framkommer bland annat att företag som är verksamt inom explosivämnesindustrin har använt multimediala studiematerial. Med teknikens hjälp har man kunnat försätta kursdeltagaren i virtuella laborationer som tydligt illustrerar kemiska förlopp. Av säkerhetsskäl skulle liknande situationer aldrig kunna genomföras i verkligheten, varför denna typ av undervisningsmaterial har varit särskilt betydelsefullt och uppskattat.

- Användning av handledare på företagen. Handledarna spelar en viktig roll för att "länka samman" individen med utbildningssystemets olika delar och genom att stödja och skapa förutsättningar för deltagarnas lärande.

- Tillgängligheten till lärare. Dessa har via lärcentra och med hjälp av distansteknik en kontinuerlig kontakt med kursdeltagarna.

- En produktionsanpassning av utbildningen som gör att den blir kostnadseffektiv och möter branschens kompetensbehov.

- Förankringen hos företagsledning. Vikten av att den högsta ledningen prioriterar och stödjer utbildningen i ett långsiktigt perspektiv och inte bara ser utbildning som ett sätt att kortsiktigt rekrytera personal.

De viktigaste inslagen i denna modell kan sammanfattas med begreppen tillgänglighet och flexibilitet. De olika exempel som redovisas ovan representerar ett nytt sätt att organisera för lärande - arbetsplatslärande. Arbetsplatslärandet innebär ett radikalt ifrågasättande av traditionell utbildning - när det gäller tider, platser, arbetsformer, pedagogik, kommunikationsformer, handledning, lärarroll m.m. Modellen innebär ett tydligt alternativ till traditionell utbildning som är utbudsstyrd, medan det som beskrivs här är en efterfrågestyrd utbildning där både innehåll, form och utförare varierar och bestäms i dialog med deltagarna. 
Erfarenheterna visar på den potential som arbetsplatslärandet har. Detta lärande kan skapa en dynamik på arbetsplatsen som gör att de anställda blir mer intresserade av utbildning. Olika delkurser kan genomföras och anpassas efter de anställdas önskemål och företagets behov. I detta sammanhang kan nämnas vikten av ledningens stöd och engagemang på arbetsplatsen för att lägga en god grund för attityder, stämning på arbetsplatsen kring medarbetarnas kompetensutveckling och lärande i arbetet.

Viktiga resultat har uppnåtts, men mycket återstår att göra om arbetsplatsen ska bli en central arena för livslångt lärande, som ett sätt att utveckla både individer och organisationer. Företagens kortsiktiga behov får inte bli styrande, utan deltagarnas intressen och önskemål måste kombineras med samhälleliga mål (som demokrati, jämlikhet och jämställdhet) och arbetsmarknadens förutsättningar.

\section{Referenser}

Svensson, L \& Åberg, C. (2001). Elearning och arbetsplatslärande. Stockholm: Bilda förlag.

Svensson, L., Ellström, P.-E., \& Åberg, C. (2004). Integrating formal and informal learning at work. The Journal of Workplace Learning. Vol. 16 No. 8, 2004 pp. 479-491
Svensson, L. \& Ljungzell, M. (2006). Arbetsplatslärande - ett sätt att utveckla individer och organisationer. APeL: Lindesberg Svensson, L. , Ellström, P.-E. \& Åberg, C. (2004) Integrating formal and informal learning at work. The Journal of Workplace Learning, No.8, p. 479491. 


\section{Case 5. Yrkesbaserat lärande. Projekt i Söderhamn åren 2002-2005}

Titel: Söderhamnsmodellen - ett lyckat projekt. Anställda får möjlighet att utvecklas på nya befattningar och arbetslösa får jobb.

Af Robert Höghielm \& Sven-Olof Larsson

\section{Bakgrund/sammanhang, problem och syfte}

Bakgrunden till föreliggande projekt är mycket enkel och självklar. Den som är arbetslös får ett jobb och varvar teori och praktik, där praktiken blir förutsättningen för teorin. Den som har jobb får chans att gå vidare och utvecklas i en ny befattning med ny kompetens. Alla blir vinnare. "Söderhamnsmodellen" eller Yrkesbaserat lärande (YBL) kallas detta arbetssätt. Modellen har utvecklats mellan Centrum för flexibelt lärande (CFL), Arbetsförmedlingen och ett antal företag. Föreliggande projekt, kallat PEOPLE, har bedrivits inom ramen för Equal, Europeiska socialfonden. Equals syfte är att bekämpa diskriminering, ojämlikhet och utestängning i arbetslivet samt verka för mångfald.

Målet med projektet har varit att stärka arbetslösa samt grupper av anställda som har en svag ställning på arbetsmarknaden genom att vidareutveckla metoder för kompetensutveckling på arbetsplatsen. Nya organisationsformer, produktionsmetoder och teknikutveckling ställer nya krav. Många anställda såväl som arbetslösa behöver utveckla sin kompetens för att stärka sin ställning på arbetsmarknaden. I annat fall finns det risk att grupper av människor hamnar vid sidan av arbetsmarknaden, i synnerhet i tider av snabba förändringar. Söderhamnsprojektet handlade om att hitta nya angreppssätt för att främja det livslånga lärandet i praktiken.

I Söderhamnsprojektet har anställda i tre privata företag erbjudits kompetensanalys, validering, vägledning och kompetensutveckling i direkt anslutning till arbetet. De som kom i fråga för delprojektet var anställda med en jämförelsevis låg formell utbildning och behov av baskunskaper för att kunna komma vidare i mer branschspecifik kompetensutveckling. Ett antal arbetslösa gick in som vikarier på de aktuella företagen, för att undvika produktionsbortfall. Vikarierna deltog också i den arbetsplatsförlagda kompetensutvecklingen.

I projekt av det här slaget är det lätt att uppfatta de arbetslösa och anställda med låg formell utbildning som målgrupper, vilka man ska "hjälpa”. I detta projekt har dock arbetet varit inriktat på systemförändring, inte att i första hand kortsiktigt "hjälpa utsatta". Tanken har varit att genom att förändra systemen minska diskriminering och utestängning på lång sikt. 
Projektets målgrupp har varit olika lokala aktörer från Söderhamn, närmare bestämt arbetsförmedlingen (AF), kommunala vuxenutbildningen (Komvux) genom Centrum för flexibelt lärande (CFL) samt näringslivet.

Syftet med studien har varit att kartlägga och beskriva den pedagogiska strategi som tillämpats inom PEOPLE- projektet Söderhamn. Följande frågeställningar har behandlats:

Hur kan den övergripande strukturen beskrivas som ligger till grund för utbildnings-verksamheten?

Kan man urskilja något mönster i den pedagogiska verksamheten?

Vilka är de mest utmärkande dragen att lära som vuxen vid arbetsplatsförlagd utbildning?

Finns det strukturella hinder för samverkan mellan de sociala parterna och de aktuella företagen?

\section{Arbetsplatserna}

De företag som ingick i studien var:

Vallviks pappersbruk AB: Bruket är en pappersmassafabrik som ägs av Rottneroskoncernen. Bruket har cirka 200 anställda och en kapacitet av 194000 ton pappersmassa per år.

Söderhamn Eriksson AB: Företaget är en av tre världsledande företag inom tillverkning av sågverksutrustning. Företaget har cirka 125 anställda.

Scandymet $A B$ : Företaget tillverkar doppvärmare och plattvärmeväxlare för industriellt bruk. Marknaden är Europa och Kina. Företaget betecknas som ett innovationsföretag.

Som ovan påpekats ingick i detta samarbetsprojekt CFL i Söderhamn, arbetsförmedlingen (AF) i Söderhamn men även ABF Hälsingekusten samt Länsstyrelsen i Gävleborg.

AF, Länsstyrelsen och ABF kontaktades med förfrågan om deltagande. När det gäller det lokala näringslivet inbjöds ett antal företag till informationsträff vid två tillfällen. Två av de tre deltagande företagen Vallviks Bruk $\mathrm{AB}$ och Scandymet $\mathrm{AB}$ anmälde då sitt intresse att delta. De tredje företaget som ingår i studien, Söderhamn Eriksson $A B$, kontaktades direkt av projektledningen med en uppmaning till företaget att delta i projektet.

Samtliga partners skrev under en avsiktsförklaring vilken behandlade deras roll i projektet. I rollen ingick att:

- vara en samtalspartner, en kunskapsbank i projektet

- delta i utvecklingen av att skapa system och förändrade regelverk för anställda som behöver höja sin kompetens för ökad anställningsbarhet

- bidra till att facklig representation finns i projektet

- bidra till att knyta redan befintliga insatser till projektet 
- möjliggöra att kompetensutvecklingsinsatser kan genomföras på arbetsplatsen

- delta i spridning och implementering av erfarenheter gjorda i projektet

- medfinansiera projektet genom egna arbetsinsatser

I projektet påpekas vidare att det är viktigt att hitta en balans mellan deltagande partners. I detta fall har tre stora intressenter deltagit nämligen; vuxenutbildning, näringsliv och arbetsförmedling. Var och en har haft olika mål med sitt deltagande i projektet. Vuxenutbildningen har den enskildes utveckling som mål, näringslivets mål är vinstmaximering och arbetsförmedlingens mål är tillväxt. Samarbetet mellan intressenterna kan liknas vid en "trebent pall". När samtliga parter ser en vinst i att delta, känner delaktighet och deltar på lika villkor råder balans och den "trebenta pallen står stadigt”. Det innebär också att parterna blir mer eller mindre låsta till varandra $\mathrm{i}$ sina ansträngningar och helhetssynen på arbetet blir viktigt samtidigt som det inte behövs byggas någon extra administration eller överbyggnad. (Att skapa en speciell organisation skulle troligen få motsatt effekt och ansvaret skulle flyttas från respektive part över till administrationen.) Utmaningen i samarbetsprojektet ligger alltså i att tillgodose samtliga intressenter och att $\mathrm{i}$ alla lägen få pallen att väga jämnt.

Vid två av företagen är åldersgenomsnittet högt och inom de närmaste tre åren kommer en fjärdedel av de anställda att gå i pension. I samband med detta har frågan uppstått hur vedertaget kunnande skall kunna överföras från den personal som slutar till de yngre som kommer att anställas för att ersätta dessa personer. I grunden handlar det om vilken sorts kompetens som man anser vara av betydelse för det enskilda företagets överlevnad.

\section{Vad gjorde man?}

Under perioden hösten år 2002 till våren år 2005 deltog 29 arbetslösa i ett utbildningsprogram som utvecklats av CFL i Söderhamn. Programmet innebar i korthet att ett urval skedde av vissa arbetssökande i samarbete med AF och berörda företag. Dessa fick möjlighet att gå in som vikarier eller att påbörja en yrkesutbildning på företaget genom att det så kallade aktivitetsstödet tillämpades av AF. Detta i sin tur kombinerades med att de utvalda personerna samtidigt genomgick Komvuxkurser från de verkstadstekniska och processtekniska gymnasieprogrammen. Utbildningsprogrammet tog ett år. De handledare som behövdes i utbildningen bekostades av företagen.

I projektet ville man prova olika metoder eller moduler för kompetensutveckling fördelat på olika företag med utgångspunkt från företagens specifika förutsättningar och intressen. Samtidigt ville man testa olika samarbetslösningar tillsammans med AF, CFL Söderhamn och det lokala 
näringslivet. Under projektet provades tre olika metoder för kompetensutveckling där syftet var att testa olika lösningar i olika miljöer. Naturligtvis begränsades detta av att företagen hade olika förutsättningar att avsätta resurser beroende på exempelvis produktionsläge. Tre olika kompetensutvecklingsmetoder utvecklades. Dessa var:

\section{Metod 1 - Praktikant med handledare}

Praktikanten gick med handledaren och lärde sig jobbet för att ersätta en anställd på kurs.

Denna metod omfattar en utbildningstid på sex månader. Den arbetslöse (praktikanten) rekryterades från AF och under tre månader fick denne utbildning av handledare så att den under de resterade fyra månaderna kunde avlösa en anställd som vidareutbildades internt eller externt. Praktikantutbildningen var till 100 \% förlagd till produktionen. Metoden testades hos Scandymet AB och Vallviks Bruk AB.

Metod 2 - Praktikant med kursplan, handledare, validering samt interna och externa kurser

Här fick praktikanten först en kursplan, nationell eller lokal. Praktikanten gick sedan med handledaren. Utgångspunkten i lärandet var arbetet, men kursplanen låg i botten. Efter kurserna fick deltagaren gymnasiebetyg genom validering. Detta gjorde utbildningen giltig på andra företag.

Den andra metoden omfattade en praktiktid på sex månader och fungerade så att praktikanten rekryterades från $\mathrm{AF}$ men fick en utbildning under alla sex månaderna av handledare. Utbildningen bestod av en eller flera kurser ur industriprogrammets nationella kursplaner samt lokala kursplaner när nationella saknades. Efter avslutad utbildning validerades praktikanten av lärare från industriprogrammet. Förutom utbildning tillsammans med handledare deltog praktikanten i interna och externa företagsutbildningar arrangerade av leverantörer och externa utbildningsanordnare. Även denna praktikantutbildning var förlagd till produktionen sånär som på företagsutbildningarna. Denna metod testades hos Söderhamn Eriksson AB.

Metod 3 - Trainees med gymnasieprogram, interna och externa kurser och handledare

Deltagare inom denna metod läste gymnasieprogrammet i processteknik, kompletterat med interna och externa kurser och därutöver fick de handledning.

Den tredje metoden omfattade en praktiktid på tolv månader och följde ett antal kursplaner från processtekniska gymnasieprogrammet och kompletterades med företagsinterna utbildningar arrangerade av företaget, leverantörer samt andra utbildningsanordnare. Utbildningen var till $70 \%$ förlagd till produktionen tillsammans med handledare och $30 \%$ 
traditionell undervisning under ledning av yrkeslärare. Efter avslutad utbildning utfärdades betyg. Metoden testades hos Vallviks Bruk AB.

För att få en uppfattning om hur projektverksamheten fungerade besöktes samtliga berörda företag under ett par veckor i slutet av januari år 2005. Under dessa veckor genomfördes 27 intervjuer med företagsledare, produktionsansvariga, anställda (handledare) samt kursdeltagare. Intervjuerna var av kvalitativ forskningskaraktär, med vilket i korthet menas att de var relativt ostrukturerade. I huvudsak behandlades följande frågeområden:

- företagets verksamhet och framtida utbildnings- och utvecklingsbehov, skäl för deltagande i projektarbetet;

- arbetsplatsförlagt lärande som pedagogisk strategi;

- att lära som vuxen, kunskapssyn;

- samverkan;

- om att tänka fritt - förändringar?

Det utbildningsprogram som tillhandahölls innehöll både yrkesträning och förberedande yrkesutbildning. Genom CFL:s försorg kombinerades delar av gymnasieskolans program, som har yrkesämnen, med en ren yrkesutbildning som skedde på en fungerande arbetsplats. Man skapade en modell som inte är en Arbetsplatsförlagd utbildning (APU), och inte en lärlingsutbildning. Det rör sig närmast om en fusion mellan yrkesteori och yrkespraktik. Modellen, som man senare valde att kalla för Söderhamnsmodellen, innebär att den läroplan som Komvux tillämpar för de yrkesförberedande programmen används i kombination med yrkesträning på en arbetsplats.

Sammanfattningsvis såg projektidén ut så här: De deltagande företagen satte ihop en önskvärd profil och fick en lista med namn från AF. Ur listan valde man ut ett antal personer. Dessa fick utbildningen av CFL samtidigt som de lärde sig jobbet på den nya arbetsplatsen. På arbetsplatsen skulle de ersätta sådana anställda, som själva var på väg att lära sig nya befattningar. Deras utbildning bestod i sin tur av att gå parallellt med handledare samtidigt som de deltog i kurser. På så sätt blev projektet en flerstegsraket; arbetslösa fick lära sig nya jobb och anställda fick utökad kompetens och nya befattningar! AF bidrog med aktivitetsstöd för de arbetslösa medan de var i utbildning. CFL erbjöd traditionell utbildning i kärnämnen och yrkesämnen och enstaka högskolekurser för de anställda. Efter utbildningsperioden erhöll kursdeltagarna dels utbildningsbevis från genomgångna gymnasiekurser, dels en utbildning i ett yrke. Det innebar således att dessa personer hade ökat sin anställningsbarhet.

\section{Resultat och effekter}

Efter avslutat projekt redovisas följande positiva resultat: 
25 av 29 deltagare gick från arbetslöshet till någon form av anställning. Av de 25 var det en person som fick avtalspension och tre personer var efter projektet tillbaka i arbetslöshet. Det är viktigt att påpeka att när det gäller deltagarens anställningsbarhet har det inte spelat någon roll ifall praktikanten har haft en kursplan i botten och deltagit i externa och interna kurser eller om denne enbart gått tillsammans med handledare.

Då Vallviks Bruk AB bjudit in den lärare som arbetat med trainees i projektet till olika interna företagsinformationer och utbildningar erhöll denna en extra fortbildning som inte var planerad.

I frågor som rör kompetensutveckling skapades en nära relation mellan företag, AF och Komvux.

Även vissa negativa aspekter framkom:

- Både yrkeslärare och handledare såg på teori och praktik som skilda enheter.

- Handledarna uppfattade sig inte som pedagoger.

- Kopplingen mellan handledare och teoretiska kurser var inte integrerad.

- Överföringen av yrkeskunnande kännetecknades av att "stå och titta på” tills man sett momentet göras tillräckligt många gånger.

Ytterligare negativa aspekter som identifierats efter avslutat projekt var ett antal utestängningsmekanismer vilka försvårat eller stört arbetsprocessen i projektet.

Den första utestängningsmekanismen behandlade praktiktidens längd. En regel vilken begränsar praktiktiden till 6 månader har till viss del upplevts som ett problem. I projektet fanns det praktikanter som behövde mellan 7 till 9 månader för att lära sig arbetet, beroende på arbetes innehåll och praktikantens bakgrund. Här begränsades man dock till 6 månader vilket gjorde att vissa praktikanter fick sämre möjligheter att lära sig en befattning och därmed sämre möjligheter att bli anställningsbara. Ett bättre system vore att anpassa praktiktiden till arbetets krav och praktikantens förutsättningar genom en överenskommelse lokalt mellan AF och arbetsgivaren.

En annan utestängningsmekanism som man stötte på var behörighetskrav för högskolestudier. I ett fall fanns önskemål om att två företagsledare skulle få gå en enstaka högskolekurs i kalkylering och budgetering. De hade båda lett medelstora företag med stor framgång och hade de nödvändiga förkunskaperna. Dessa förkunskaper hade emellertid förvärvats i arbetet och inte via gymnasieskolan. Högskolan erbjöd därför två vägar: en var att företagsledarna läste in behörigheten vid den kommunala vuxenutbildningen för att få de nödvändiga betygen/uppfylla de formella förkunskapskraven eller att utbildningen köptes som uppdragsutbildning. Tyvärr tilltalade inget av förslagen företagsledarna varför det 
hela rann ut i sanden. Ett sätt att komma tillrätta med denna utestängningsmekanism vore att titta närmare på den lösning som finns i Finland när det gäller vuxnas möjlighet att studera vid högskola. Där kan vuxna studera vid högskola även utan formell behörighet.

Den tredje utestängningsmekanismen som rapporterades var de krav som AF ställer på de arbetslösa då dessa, trots deltagande i utbildning, ständigt ska stå till arbetsmarknadens förfogande. De arbetslösa praktikanterna, som blev antagna till trainee-utbildningen, blev under utbildningens gång uppmanade att söka vissa lediga jobb av sina handledare på AF. I det fall de erhållit det angivna och tidsbegränsade jobbet skulle de naturligtvis vara tvungna att lämna pågående utbildning. (Möjligen skulle de kunna söka och bli antagna på nytt till nästa utbildningsomgång.) I samband med detta ställs frågan om inte denna regel är kontraproduktiv. Här försvåras möjligheten att via den aktuella och påbörjade utbildningen få ett fast jobb med långsiktig lösning på grund av att man ska efterleva en mer kortsiktig regel med innebörden att arbetslösa (i detta fall praktikanter) alltid ska stå till arbetsmarknadens förfogande.

I studien betonas vidare att den pedagogik som tillämpats i projektet tar fasta på yrkeskultur, den yrkespraxis som utvecklats inom ett aktuellt yrke samt koncentrerar sig på specifika yrkeskunskaper. Pedagogiken som tillämpats bygger på att man utgår från den aktuella yrkeskulturen som gäller för det yrke man skall utbildas till. Vidare får yrkespraxis en framträdande roll eftersom den studerande befinner sig mitt i yrkesverksamheten, medan tillhandahållandet av specifika yrkeskunskaper sker genom mer eller mindre traditionella kurser, som är mindre framträdande. Utbildningarna betraktas inte heller som en allmän Komvuxutbildning, utan mera som en yrkesutbildning.

I fråga om begreppen yrkeskultur, yrkespraxis och yrkeskunskaper definieras dem i studien på följande sätt.

Yrkeskultur handlar om att överföra både tekniskt kunnande och normativa moment, begreppet definieras som överförande av kollektiva erfarenheter. Yrkeskulturen bestämmer hur yrkespraxis utformas men också vad som kan erkännas som yrkeskunskap. Ett yrke utövas alltid i en viss social kontext som i slutändan formar yrkeskulturen.

Med yrkespraxis avses att följa vissa regler eller procedurer som kan benämnas som yrkestraditioner. Den etiska dimensionen av begreppet praxis kan ingå i begreppet yrkespraxis men viktigare är att framhålla att den innehåller en anda som inte kan meddelas andra direkt genom formella beskrivningar. Genom övningar tillägnas ett visst förfarande som kan vara ett av flera möjliga. Dessa i sig rymmer en yrkespraxis som innebär att följa vissa regler eller procedurer som kan benämnas traditioner inom ett yrke. Yrkespraxisen förändras genom en fortgående process. I alla yrken, även i så kallade "nya yrken”, finns det både en yrkeskultur och en yrkespraxis. Att förstå och tydliggöra dessa är en förutsättning för att kunna tillhandahålla en god yrkesutbildning. 
Yrkesskickligheten och yrkeskunskapen består i att handlingen utförs så att man vet vad man gör, gör det med avsikt efter reflektion och övning. En erfaren yrkesman eller yrkeskvinna "vet” vad som skall göras. Han eller hon behärskar sitt ämnesstoff och utförandet av arbetsuppgiften i så hög grad att han eller hon inte alla gånger med ord kan beskriva vad som sker.

Söderhamnsprojektet har mynnat ut $\mathrm{i}$ en modell för yrkesutbildning och yrkesbaserat lärande. Denna modell (visas nedan i figur 1) behandlar begreppen yrkeskultur, yrkespraxis och yrkeskunskap.

Yrkets beståndsdelar

Yrkeskultur

I produktionen på arbetsplatsen

Arbetsplatsen

\section{Yrkespraxis}

Genom att delta i produktionen

Arbetsplatsen

miljöer)

\section{Yrkeskunskap}

Lärställe (lärande i olika

Alla former av kunskap

Undervisning i skolliknan-

de sammanhang

Utförandet av yrkesarbete

bestämmer när teorin skall

behandlas:

- kan vara teoretisk kurs

- kan vara delförklaringar

av produktionen med hjälp

av pedagogiska handledare

Figur 1: Sammanfattande bild över Söderhamnsmodellen

Framväxten av den så kallade Söderhamnsmodellen har skett över tid. De som deltagit i projektet har inte planerat eller tänkt i termer enligt den vänstra delen av figuren (yrkets beståndsdelar) utan man har arbetat i den högra delen (lärställe). Arbetssättet har möjligtgjorts av att man inte nödvändigtvis tänkt i traditionella kursplaner (som är tänkta att förbereda för ett yrkesliv) utan det produktiva arbetet har fått sätta agendan för vilka delar av kursplanerna som kan vara av intresse att fördjupa sig i.

Vidare grundar sig Söderhamnsmodellen på följande punkter: 
- Teori och praktik ska inte hållas isär. Yrkesteori och yrkespraktik ska slås samman, dock på yrkespraktikens villkor.

- Reell kompetens ska vara utgångspunkt vid bedömning av vad den enskilde arbetstagaren kan. Reell kompetens har alltså stått i fokus i projektet då de flesta av kursdeltagarna har många års yrkeslivserfarenhet, vilket beaktats vid utfärdandet av betyg eller intyg.

- Ambitionen är att "avskolifiera" utbildningsverksamheten. (I projektet har man undvikit att nämna att Komvux formellt varit inblandat.)

- Fokus ska ligga på vad individen efterfrågar - inte vad utbildningsanordnare kan erbjuda. Efterfrågestyrt - individperspektivet har dominerat planeringen av utbildningsverksamheten.

- Det är de vuxnas lärande som ska betonas - inte utbildningsformerna.

- Ett nära samarbete med deltagande företag betonas, vilket inneburit lyhördhet för deras behov. Vidare poängteras flexibelt samarbete med de sociala parterna, framförallt AF.

- Slutligen påtalas också att om Söderhamnsmodellen ska kunna fungera på ett optimalt sätt så krävs det att det finns ett lärcenter. Ett center som är uppbyggt som ett nätverk med olika noder för olika former av läraktiviteter.

Punkt ett i listan ovan bör kommenteras ytterligare då relationen mellan teori och praktik flitigt diskuterats i detta projekt. Skillnaden mellan praktisk och teoretisk kunskap betraktas vanligtvis som att det förra handlar om rent kroppsarbete och att hantverksarbetets tankearbete inte är särskilt komplicerat. Mot detta kan hävdas att praktisk kunskap kräver hög abstraktionsförmåga därför att hantverkaren behöver bilda sig en uppfattning om hur det tänkta föremålet skall se ut och fungera. Detta är en viktig aspekt att beakta. En rimlig utgångspunkt är att det i alla praktiska yrkeshandlingar, generellt sett, alltid finns en kombination av intellektuell och manuell verksamhet närvarande. I Söderhamnsprojektet har, som sagt, ambitionen varit att överbrygga klyftan mellan teori och praktik.

Vidare vad gäller relationen mellan teori och praktik aktualiseras problemet med att gymnasieskolans institutionaliserade miljöer för lärande har kommit att få karaktären av en allmän förberedelse för ett yrkesliv som alltmer blivit svår att förutsäga till sitt innehåll. Det finns svårigheter med att $\mathrm{i}$ en formell skolsituation fånga det som en arbetspraktik kan erbjuda i form av interaktion mellan den lärande och de kunder som finns inom yrket. Här nämns också att de gymnasiala yrkesutbildningarna ofta intar ett skolperspektiv på arbetsplatsförlagd utbildning. Man närmar sig arbetslivet genom att se efter var praktiken skall passa in i de teoretiskt inriktade kurserna som skolan har, istället för att se efter på vilket sätt praktiken kan förklaras med hjälp av teoretiska kurser. Det arbetssätt som karaktäriserat Söderhamnsmodellen är man inte tänkt i traditionella kursplaner utan att det produktiva arbetet (praktiken) har fått vara styrande. 
Att arbeta enligt Söderhamnsmodellen anses därför vara ett sätt att komma tillrätta med glappet mellan formell utbildning och yrkesliv.

En slutsats som dras efter avslutat projekt är att Söderhamnsmodellen på ett mycket bra sätt lyckats tillgodogöra de berörda parternas behov, både ur ett individperspektiv men även ur ett företagsperspektiv. Sammanfattningsvis sägs Söderhamnsmodellen ge upphov till ett Yrkesbaserat lärande, YBL.

\section{Referenser}

Ekelöf, E. (2005). En ny yrkesutbildning. Erfarenheter från PEOPLE delprojekt i Söderhamn. Dokumentation av konferensen i Söderhamn den 20 maj 2005. Arbetslivsjournalisterna.
Höghielm, R. \& Larsson, S-O. (2006) Yrkesbaserat lärande - Erfarenheter från PEOPLE delprojekt i Söderhamn 2002 till 2005. Söderhamn: Centrum för flexibelt lärande. 


\section{Case 6. Udvikling af en lærende omgang med arbejdet}

Seniorprojekt om fastholdelse af medarbejdere gennem kompetenceudvikling og organisatorisk læring

Case af Mette Iversen

Denne case omhandler et seniorprojekt om fastholdelse af medarbejdere gennem kompetenceudvikling og organisatorisk laring på et stort plejehjem i Oslo kommune. I casen beskrives hvordan arbejdspladsen anvendes som leringsarena for formel og uformel læring såvel på det individuelle som på det organisatoriske plan. Strategien er karakteriseret ved en samtidighed af interventioner på arbejdspladsen. Det fremgår at samspillet mellem den formelle og den uformelle læring i organisationen udgør et dynamisk felt for udvikling af modeller til løsning af såvel individuelle som organisatoriske problemstillinger.

Casen fortæller samtidig historien om hvordan en strategi om tiltrækning og fastholdelse af den bedste arbejdskraft bliver udgangspunkt for opbygningen af et læringssystem med deltagelse af alle på arbejdspladsen.

\section{Baggrund og sammenhreng}

Casen bygger på resultater fra et udviklings- og forskningsprojekt igangsat på det største plejehjem i Oslo kommune. Den omhandler et seniorpolitisk projekt der er tilrettelagt som organisatorisk læring. Seniorprojektet er igangsat som led i en indsats der allerede er i gang på arbejdspladsen omkring fastholdelse og kompetenceudvikling. Seniorprojektet er også et led i en national satsning på seniorpolitik i arbejdslivet. Den nationale satsning har baggrund i en udvikling der på sigt vil føre til alvorlig mangel på arbejdskraft og som er karakteriseret ved:

- At den demografiske udvikling går i retning af at stadig større dele af befolkningen består af ældre og med en faldende andel af yngre mennesker.

- At der samtidig kan iagttages en stigning i sygefravær på arbejdspladserne.

- At der kan registreres en øgning af tidlig pensionering.

En seniorpolitisk strategi

For at imødegå denne udvikling iværksættes en seniorpolitisk strategi med henblik på 1) at gøre arbejdet mere attraktivt 2) at forebygge ned- 
slidning og 3) at mindske sygestatistikken. Dette sker med henblik på en fastholdelse af ældre medarbejdere på arbejdsmarkedet.

Seniorprojektet (SP) som sættes i gang på plejehjemmet er tilrettelagt som et senior- og livsfaseprojekt (2001-2005) hvilket betyder at det ikke alene retter sig mod ansatte over 45 år (seniorer) men også mod forskellige personalegrupper med livsfasebestemte behov. Projektets formål er dermed ikke (alene) at udvikle seniortiltag med den hensigt at forlænge den gennemsnitlige fratrædelsesalder på plejehjemmet, men der indgår samtidig et bredere formål i projektet om at rekruttere, beholde og videreudvikle kompetent arbejdskraft i alle aldre. Foruden varetagelsen af dette bredere formål har senior- og livsfaseprojektet også det formål at skulle følge op på resultater fra et allerede igangsat og delvist overlappende projekt på plejehjemmet (Projekt Langerud 2000-2002) (PL). Seniorprojektet (SP) har dermed også som opfølgningsprojekt til formål at vende en arbejdspladsudvikling præget af flere sammenhængende problemstillinger: 1) Rekruttering af arbejdskraft til pleje- og sygehjemmet 2) Fastholdelsesproblemer 3) Problemer med højt sygefravær med mange langtidssyge og 4) Utilstrækkeligt uddannet personale. I den del af seniorprojektets formål om at følge op på PL indgår derfor de initiativer som allerede er igangsat for at afhjælpe situationen på plejehjemmet omfattende tre hovedområder: 1) Organisationsœndring med omorganisering af arbejdspladsen og ny ledelsesstruktur 2) Kompetenceafklaring og formel kompetenceudvikling gennem virksomhedsforlagt uddannelse og 3) Mentorordning og vejledning på arbejdspladsen - seniorinstruktører og arbejdspladspraktik. Seniorprojektet søger bevidst at videreføre centrale målsætninger og perspektiver fra PL hvor det at gøre hele plejehjemmet til en lærende organisation står centralt. ${ }^{4}$

Seniorprojektets samlede formål er dermed:

- At forebygge fysisk og psykisk nedslidning, forlænge den gennemsnitlige fratrædelsesalder og tilrettelægge arbejdet specielt for seniormedarbejdere.

- At rekruttere, beholde og videreudvikle kompetent arbejdskraft i alle aldre.

- At anvende flerkulturelle ressourcer hos de ansatte og i lokalmiljøet.

- At følge op på tiltag og resultater fra et forudgående projekt igangsat med henblik på at vende udviklingen på arbejdspladsen.

\footnotetext{
${ }^{4}$ Det overordnede mål som var hentet i Oslo kommunes arbejde med målstyret kompetence var at udvikle plejehjemmet til en lærende organisation: "A tilstrebe kontinuerlig forbedring, ha en flesibel struktur, et kreativt klima, løse problemer der de hører hjemme og la kompetanse styre mer enn formell makt. Ledelsesmessig kjennetegnes den lerende organisasjonen av processorientering og kommunikation.” (Målstyrt kompetanseutvikling i Oslo kommune, 1997)
} 


\section{Hvad belyses?}

Casen beskriver senior- og livsfaseprojektet (SP) herunder hvordan, dvs. med hvilke strategier og metoder det følger op på og videreudvikler det forudgående projekts resultater og processer. I artiklen belyses hvordan SP arbejder konkret på at tilrettelægge arbejdsforholdene sådan at den gennemsnitlige pensionsalder øges. Der redegøres for hvordan dette sker gennem anvendelse af kompetenceudvikling og organisationslæring med det formål at opbygge et permanent læringssystem på arbejdspladsen baseret på medvirkning og inklusion, dvs. med deltagelse af alle. Der fortages en sammenfatning af hovedelementer i seniorprojektets strategi inden for et læringsperspektiv hvor arbejdspladsen anvendes som læringsarena for alle ansatte med det formål at udvikle virksomheden til en lcrende_organisation. Strategien belyses nærmere idet den karakteriseres ved sin bredde og ved dens samtidighed af interventioner på arbejdspladsen, dvs. at den omfatter forskellige afdelinger og funktioner samt forskellige niveauer i organisationen - rettet mod såvel individuel kompetenceudvikling og læring (formel og uformel) som organisatorisk læring. Det hele sættes i perspektiv af ideen bag strategien som er at en velfungerende arbejdsplads vil tiltrække den bedste arbejdskraft og forebygge nedslidning og tidlig opsigelse. I casen beskrives foruden 1) projektets baggrund og 2) hvad man faktisk gjorde også 3) hvordan projektets resultater kan gøres op herunder 3.1) hvordan projektet selv vurderer egne resultater.

Artiklen belyser dermed følgende tre hovedområder:

1. Metoder til kompetenceudvikling og organisatorisk læring udviklet i forhold til

2. Fformel og uformel læring set og anvendt som et dynamisk (spændings-)felt.

3. Forudscetninger for anvendelse og italesættelse af praksis og erfaringer med praksis dvs. omgang med og håndtering af arbejdet på en lærende måde.

4. Strategier og metoder til etablering af et læringssystem på arbejdspladsen hvor eksisterende strukturer synliggøres, omfunktioneres og anvendes såvel på et individuelt som et kollektivt organisatorisk plan.

Dermed gives et konkret forskningsbaseret grundlag for:

1. En vurdering af hvad der henholdsvis understøtter og hæmmer læring med arbejdspladsen som læringsarena.

2. En indkredsning af leringsbetingelser og forudscetninger for de indvundne resultater.

3. En egentlig vurdering af såvel de overordnede projektstrategier som af de metoder og modeller der er udviklet og benyttet i projektet. 
Langerud Sykehjem - en institution i Bøler Bydel ${ }^{\mathbf{5}}$

Langerud plejehjem (LP) er med sine 250 ansatte og i alt 160 sengepladser plus et dagcenter med 50 hjemmeboende det største plejehjem i Oslo Kommune. Langerud Sykehjem omtales i denne case som et plejehjem men det skal i denne præsentation af arbejdspladsen bemærkes at der er tale om et plejehjem for ældre som er syge. De ansatte har derfor en anderledes sammensætning (med mange sygeplejersker ansatte) og en mere specialiseret og omfattende plejefaglig viden end det er tilfældet for personalet på et almindeligt plejehjem. LP var gennem 25 år og helt frem til tidspunktet for Projekt Langeruds start i 2000 indrettet som en hierarkisk opbygget organisation med i alt 8 afdelinger med sygeplejersker indsat som fagligt administrative ledere. Afdelingerne var indtil da flerfaglige med alle funktioner integreret og med meget lille udveksling på tværs i organisationen. Den enkelte afdeling blev drevet meget selvstændigt med en del indbyrdes konkurrence afdelingerne imellem og derudover var der et stcerkt fokus på driften. Sygehusdriften var præget af mange langtidssygemeldinger, og der var på grund af vanskeligheder med at rekruttere hjælpeplejere og sygeplejersker en løbende mangel på arbejdskraft.

\section{Afdækning af arbejdspladsproblemer}

I slutningen af 1990'erne viser pleje- og sygehjemmet tegn på at der er noget helt galt. En kombination af flere basale faktorer har tilspidset situationen, og man er ikke længere i stand til at tiltrække hverken den bedste arbejdskraft eller tilstrækkelig arbejdskraft i det hele taget. Dertil kommer at virksomhedskulturen er for nedadgående idet arbejdet på virksomheden er præget af konflikter, af mange sygemeldinger og langtidssyge, og dertil af et løbende underskud af faguddannede. Et konsulentfirma bliver bedt om at udarbejde en analyse af plejehjemmet som grundlag for udarbejdelse af en strategi for tiltag på arbejdspladsen til en løsning af problemerne.

Resultaterne af analysen viser at den daglige pleje af patienterne er tilfredsstillende, men der peges på problemer med to forhold:

1. Plejehjemmets organisering og ledelse.

2. Et markant underskud af faglig kompetence hos personalet.

Analyseresultatet afstedkommer en beslutning om at igangsætte et $u d v i k$ lingsprojekt rettet mod en forbedring af arbejdspladsens organisering, af dens rekrutterings- og kompetencestrategier og af den generelle situation på LP præget af højt sygefravær og arbejdsmiljøproblemer. Efter det analytiske indspil fra konsulentfirmaet igangsættes et udviklingsprojekt (PL

\footnotetext{
${ }^{5}$ På grund af ændringer i det kommunale bydelskort skiftede plejehjemmet bydel midt i projektperioden til Østensjø bydel.
} 
2000-2002) hvor der skal arbejdes med rekruttering og med kompetenceudvikling af personalet på plejehjemmet.

Organisationsændring - omorganisering af arbejdspladsen og ny ledelsesstruktur

Man vurderer imidlertid også at der skal organisationsændringer til for at bedre situationen på plejehjemmet. Derfor foretages der en omorganisering, hvorefter plejehjemmet inddeles i 4 sektioner: 1) En omsorgssektion (den største) inddelt i 8 afdelinger, en tryghedsafdeling og et dagcenter med ansvar for primæropgaverne og tre mindre støttesektioner. 2) En sektion for økonomi, personale og information. 3) En sektion for fag og kompetence bestående af sygeplejersker og fagkonsulenter med ansvar for opfølgning på uddannelsestiltag. 4) En sektion for kultur, service og beskceftigelse med beskæftigelsesterapeuterne og de minoritetssproglige praktikanter. Den største organisatoriske ændring er at hjælpeplejere (typisk med videreuddannelse) bliver indsat som arbejdsledere på afdelingerne i omsorgssektionen samtidig med at de deltager i den daglige pasning og pleje af patienterne. Dette sker samtidig med at der indføres en ny ledelsesstruktur, hvorefter sygeplejerskerne får frataget deres linjeansvar i omsorgssektionen og derefter bliver placeret i en selvstændig sygeplejerskebase i sektionen for fag og kompetence ( i alt 20 sygeplejersker, 2 fagkonsulenter og en sektionsleder). Dette sker med henblik på at fremme fleksibilitet og tilgængelighed i hele organisationen. Ledergruppen som består af institutionschef og fire sektionsledere er orienteret mod ledelsesstrategier rettet mod fastlæggelse af mål og klar kommunikation. ${ }^{6}$

Strategiplan om formel kompetenceudvikling og organisationslæring Planen for Projekt Langerud består derudover i en rekrutterings- og fastholdelsesstrategi der indbefatter en kombination af: 1) Formel kompetenceudvikling som er virksomhedsforlagt og særligt tilrettelagt for ansatte der også skal lære mens de arbejder dvs. med uddannelsespraktik og vejledning på arbejdspladsen og: 2) Organisationslcering som hovedvirkemiddel herunder en systematisk metodisk anvendelse af en række små og store læringstiltag i enkeltafdelinger og på tvœrs i organisationen. Der tages afsæt i arbejdspladsens praksis og i erfaringer med praksis. Interventionen er karakteriseret ved at der indgår en samtidighed/flerhed af interventioner og ved at den i sit perspektiv er rettet mod en involvering af hele organisationen.

Seniorprojekt med arbejdspladsen som læringsarena

I sommeren 2001 starter forhandlingerne mellem seniorprojektets aktører Senter for Seniorpolitik (SSP), Arbejdsforskningsinstituttet (AFI) og Langerud Plejehjem (LP) om at igangsætte et seniorpolitisk projekt på LP

\footnotetext{
${ }^{6}$ Dette blev en model for arbejdsorganisering som varede ved helt til slutningen af seniorprojektet i 2005, hvor den blev taget op til diskussion.
} 
som et led i bydelens satsning. På det tidspunkt er det igangværende projekt (PL) som nævnt i fuld gang med en omorganisering af arbejdspladsen og en omfattende satsning på kompetenceudvikling af personalet gennem formel uddannelse og praktikvejledning på arbejdspladsen. SSP var opmærksom på den igangværende udvikling af plejehjemmet og specielt den meget vellykkede instruktørordning (mentorordning med oplæring og vejledning) omfattende den del af personalet som er særlig udsat på grund af nedslidning.

Fra seniorprojekt til livsfaseprojekt - mod et inkluderende arbejdsliv Det er inden for en samlet periode på 4 år (2001-2005) at seniorprojektet hvis igangsætning oprindelig er inspireret af den seniorinstruktørordning som blev igangsat på plejehjemmet af PL udviklede sig til et livsfaseprojekt med indføring af et lceringssystem som kom til at omfatte hele plejehjemmet. Udviklingen i måden at tænke seniorprojekt på skyldes ikke mindst den indstilling der er hos sygehusledelsen og de ansatte på plejehjemmet over for læring og kompetenceudvikling generelt og som en måde at forbedre arbejdet og arbejdspladsen på. ${ }^{7}$ Der arbejdes med forebyggelse af nedslidning gennem bred satsning på kompetenceudvikling og på organisationsudvikling. Seniorprojektets sigte er at tilrettelægge arbejdsforholdene sådan at den gennemsnitlige pensionsalder øges. For at nå dette mål skal plejehjemmet gøres til en attraktiv arbejdsplads, et sted hvor man ønsker at blive ansat og hvor de ansatte har lyst til at blive og fortsætte med at arbejde i en sen alder. Strategien er baseret på en livsfaseorienteret personalepolitik for alle ansatte, hvor der udvikles tiltag som:

a. Forebygger fysisk og psykisk nedslidning fra ansættelsestidspunktet.

b. Skaber en arbejdsplads der tilpasser arbejdet til medarbejdernes forskellige livsfaser hvad enten det drejer sig om ansatte med småbørn, ansatte under uddannelse, ansatte der er blevet ældre og/eller ansatte med nedsat arbejdsevne.

Kompetenceafklaring og efterfølgende formel kompetenceudvikling gennem virksomhedsforlagt uddannelse

Der foretages kompetenceafklaring i form af en systematisk kortlægning af den enkelte medarbejders kompetencer og uddannelsesønsker som følges op med tilbud om uddannelse. Hertil anvendes klinisk kompetencestige et trinvist opkvalificeringsprogram udarbejdet af oplæringsetaten ${ }^{8}$ med henblik på at:

\footnotetext{
${ }^{7}$ Der blev under projektperioden ansat en ny sygehusledelse med pædagogisk baggrund i stedet for den traditionelt sygeplejefaglige baggrund dette var med til at profilere plejehjemmet som en lærende organisation.

${ }^{8}$ Oplæringsetaten i Norge er den instans der bl.a. arbejder med hvordan medarbejderne kan få den formelle kompetence.
} 
- Sikre viden og færdigheder som er relevant for arbejdsområdet/ansættelsen

- Hæve kvaliteten i den kommunale helsetjenestes tilbud

- Tilfredsstille kvalitetskrav fra samfundet

- Beholde og tiltrække kompetent personale

- Stimulere til faglig fordybelse

Plejehjemmet igangsætter i alt 10 bedriftsinterne kurser udviklet på forskellige niveauer.

Deltagelse i kompetencestigen er frivilligt og alle kan deltage i overensstemmelse med virksomhedens ønsker og prioriteringer. Den faglige vurdering af deltagerne med godkendelse af den enkeltes dokumentation for gennemført niveau foretages af den nærmeste leder. Da der tilstræbes regelmæssig opstart på niveauerne, og der her finder en vis vurdering og sortering sted ligger der samtidig en opfordring til den enkelte om at foretage en regelmæssig kortlægning/afklaring og dokumentation af egen kompetence.

Bedriftsintern hjælpeplejeruddannelse

I 2001 udvikler plejehjemmet gennem et samarbejde med Oplæringsetaten og Sogn videregående skole en bedriftsintern hjcelpeplejeruddannelse (BIH) rettet mod formel opkvalificering af personale der løser primæropgaverne på plejehjemmet. BIH er en særligt tilrettelagt virksomhedsforlagt og - tilpasset uddannelse med et todelt formål:

1. At udvikle en model der er tilpasset arbejdslivets behov for læring på arbejdspladsen.

2. At gennemføre og afprøve modellen på plejehjemmet med 15 ufaglærte hvoraf 3-4 er minoritetssproglige. Norskoplæring er en del af projektet.

Der igangsættes oplæring og vejledning af nyansatte i grundlæggende sygepleje på plejehjemmet lige som der udvikles handlingsplaner for modtagelsen af nyansatte herunder udenlandske sygeplejersker. På de arbejdspladsforlagte kurser er de lererkrcefter som anvendes både arbejdspladsinterne og -eksterne undervisere hentet ind fra uddannelsesinstitutionerne. Til uddannelse og kurser på virksomheden er der tilknyttet vejledere ude i afdelingerne som har en oplcringsfunktion og som checker om deltagerne har forstået kursusindholdet og lært det de skal i praksis. Lærere og vejledere holder derfor løbende møder, hvor de drøfter teoripraksis-problemstillinger. Såvel i BIH som i klinisk kompetencestige er teori-praksis-samspillet et helt centralt omdrejningspunkt. Det gælder om at kunne løfte praksis op på et teoretisk niveau lige som den enkelte omvendt skal kunne anvende teori på praksis. Teori-praksis-koblingen foregår gennem en særlig tilrettelæggelse af kurser og uddannelse sådan at 
deltagernes arbejdspladserfaringer_inddrages $i$ undervisningen. Men det foregår også ved at eks. deltagerne på BIH arbejder på plejehjemmet samtidig med at de uddanner sig. De har fri til at deltage i undervisningen, men må forberede deres undervisning i fritiden. Praksisfærdigheder indøves på arbejdspladsen med støtte og kontrol fra en vejleder på afdelingen (uddannelsespraktikordning på egen arbejdsplads). Den studerende udarbejder selv checklister over hvad de har gennemgået i praksis/praktik og vejlederen står med sin underskrift af disse som garant for det lærte. Fagkonsulenterne fra afdelingen for 'fag og kompetence' på plejehjemmet har det overordnede ansvar for at tilrettelægge undervisningen i praktiske færdigheder i afdelingen. ${ }^{9}$ På BIH gennemføres eksamen med anvendelse af realkompetencevurdering ${ }^{10}$ og hvor den praktiske del af den afsluttende eksamen foregår på plejehjemmet i en anden afdeling end der hvor deltagerne arbejder til daglig.

Mentorordning og vejledning på arbejdspladsen - seniorinstruktører og arbejdsplads-praktik

Som led i en fastholdelsesstrategi indføres en instruktørordning på plejehjemmet hvor hjælpeplejere som er særlig ramt af nedslidning får tilbudt en specialstilling som hjcelpeplejerinstruktører ${ }^{11}$ I starten er ordningen dog mere rettet mod praktikanterne idet den skal afhjælpe en vanskelig bemandingssituation i forbindelse med arbejdstræning af især minoritetssproglige praktikanter.

Instruktørordningen opstår som en del af omorganiseringen af plejehjemmet. Den oprindelige hensigt med instruktørordningen er som følger:

- At afhjælpe en vanskelig bemandingssituation på plejehjemmet

- At tilbyde praktikplads for indvandrere med ønsker og behov for arbejdspraktik

- At tilbyde nedslidte, syge og/eller ældre hjælpeplejere et fysisk mindre belastende job

- At bruge viden og erfaringer fra erfarne hjælpe plejere som vejledere/lærere for ufaglærte

Instruktørordningen havde stor bevågenhed i den norske presse, hvor den blev rost og omtalt i lang tid efter dens indførelse. Den blev samtidig af SSP betragtet som et eksempel på et vellykket seniorpolitisk tiltag omkring en bevidst anvendelse af medarbejdernes viden og erfaringer gennem oprettelse af specialfunktioner. Seniorinstruktørordningen er dermed

\footnotetext{
${ }^{9}$ Det nærmere indhold i den virksomhedsrettede tilrettelæggelse af BIH og den anvendte pædagogik og didaktik er beskrevet i bilagsdelen omhandlende den norske case.

${ }^{10}$ Realkompetencevurdering er i Norge et tilbud til alle voksne som ønsker at få vurderet deres samlede kompetencefelt.

${ }^{11}$ Ordningen med instruktører var et af de mest profilerede seniorpolitiske tiltag i Norge i perioden 2000-2005, instruktører blev indbudt til at holde oplæg ude omkring i landet og ordningen blev løbende omtalt i den norske presse. instruktører blev indbudt til at holde oplæg ude omkring i landet og ordningen blev løbende omtalt i den norske presse.
} 
et centralt omdrejningspunkt for en seniorpolitisk indsats på plejehjemmet. I projektet gjordes en række erfaringer med seniorinstruktørordningen som er beskrevet nærmere i casematerialet vedrørende den norske case i bilagsdelen.

Læringssystem på arbejdspladsen som virkemiddel

Arbejdspladsen bliver i starten af projektet gennemgået med henblik på en vurdering af hvordan indsatsen kan være, dvs. med henblik på at der skal „gøres noget med“ organisationen (Eikeland 2006 p. 63). Opmærksomheden rettes mod forskellige områder i organisationen hvad enten det drejer sig om arbejdsmiljø, samarbejde, kommunikation, organisering, arbejdsdeling, ledelse, uddannelse eller motivation - der dermed inddrages som 'genstand' for en mulig intervention. Målet er opbygning af et permanent lceringssystem på arbejdspladsen som de ansatte selv (og brugerne af institutionen) tager ansvar for. Ved læring forståes her ikke den læring der finder sted i 'klasserum' gennem tilegnelse af et givent lærestof, men derimod en: „systematisk evaluering og forbedring av arbeidsformer, arbeidsdeling, organisering, arbeidsmiljø, ledelse o.a. med henblikk på målopnåelse for både enkeltpersoner og kollektiv og på grunnlag av sammenfatning og analyse av egne personlige og kollektive erfaringer fra arbeidet (organisasjons- og yrkespraksis)“ (Eikeland 2006 p. 63).

Arbejdsorganisation og udviklingsorganisation

I strategien skelnes der basalt mellem arbejdsorganisation og udviklingsorganisation. Arbejdsorganiseringen er den måde hvorpå 'totalopgaven' med at udvirke et givent produkt er organiseret. I arbejdsorganisationen ses en tendens til at udskyde opgaver som ikke er driftsopgaver med risiko for at organisationen 'stivner' i bestemte måder at løse opgaver på. Forbedrings- og udviklingsopgaver bliver dermed typisk ikke løst i arbejdsorganisationen. I udviklingsorganisationen løses permanente forbedrings- og udviklingsopgaver, og den inddrager i princippet alle. Til forskel fra projektorganisationen hvor der arbejdes med delopgaver i tidsbegrcensede perioder er udviklingsorganisationen permanent og i princippet omfattende alle ansatte og alle dele af organisationen.

Der arbejdes i projektet med at skabe en bedre afbalancering af de to organisationsformer ved at udviklingsorganisationen styrkes og gøres permanent og ved at der veksles imellem dem når medarbejderne skifter mellem deltagelse i arbejds- og i udviklingsorganiseringen. Der er ikke tale om et skift mellem to fysisk adskilte organisationer men om to forskellige modus, dvs. to forskellige former eller måder at arbejde (sammen) på som gensidigt befrugter hinanden. For at dette skal komme til at fungere og virke i praksis forudsætter det: 1) fcelles forståelse og 2) deltagelse af alle på arbejdspladsen. 
Arbejdet med at skabe fælles forståelse og med deltagelse (medvirkning) I projektet arbejdes med at skabe eller udvikle fcelles forståelse hvor man over for personalet forsøger at gøre klart hvad der adskiller læringsfora fra planlægnings-, beslutnings- og informationsmøder. Derudover arbejdes i projektet basalt med medvirkning, og der bliver især i starten af projektet taget flere initiativer til fremme af dette aspekt eksempelvis gennem afholdelse af:

- En dialogkonference for ledere i bydelen

- Et informationsmøde for gruppen af medarbejdere over 45 år ved plejehjemmet (seniorer).

- En heldags dialogkonference på plejehjemmet for den samme gruppe om seniorernes vilkår og situation.

På dialogmøderne opsamles medarbejdernes forslag til seniorpolitiske tiltag som dels gives videre til ledelsen der indarbejder det i plejehjemmets handlingsplan, dels indarbejdes direkte i projektet. Dette er metoder som udgør de nødvendige indledende faser i opbygning af et læringssystem baseret på medvirkning dvs. 1) hvor alle kan deltage 2) med arbejdspladsens praksis som omdrejningspunkt, og 3) hvor deltagernes forskellige erfaringer kan komme til orde. Medvirkning defineres af projektet selv ved:,,..at den eller de berørte er med og påvirker det som skjer i forskjellige faser $i$ en beslutningsprocess eller i løsningen av et problem eller en opgave" (Eikeland og Berg 1997 p. 20). Der arbejdes med fcelles forståelse i organisationen og hos medarbejderne og med praktisk trcening. Gennem frelles forståelse vil medarbejderne ikke bare 'gøre tingene rigtigt' (dvs. som foreskrevet) men også 'gøre de rigtige ting'(dvs. som fremkaldt af situationen), og dette er afgørende for at få læringssystemet til at trcede frem og virke i organisationen. I projektet tages der udgangspunkt i enkeltafdelinger med det sigte at få det til at brede sig til andre afdelinger og dermed til at omfatte stadig større dele af organisationen. I praksis blev læringssystemet ikke udbredt til hele arbejdspladsen hvilket til dels begrundes i at det ikke lykkedes at skabe den nødvendige fælles forståelse (Eikeland 2006).

Etablering af mødepladser gennem synliggørelse, omfunktionering og anvendelse af eksisterende fora

Som et led i opbygningen af et læringssystem på arbejdspladsen og udvikling af en lerende omgang med arbejdet, arbejdes der med refleksionsgrupper og med etablering af mødepladser som er åbne for alle slags synspunkter, og hvor den enkeltes arbejdserfaringer kan komme til udtryk - på tvcers af organisationen. Der foretages en analyse af alle eksisterende mødefora i organisationen (eks. afdelingsmøder, medarbejdersamtaler, kvalitetscirkler m.m.) som derefter udvcelges og omfunktioneres til anvendelse med læring for øje. Målet er at udvikle evnen til at føre en dia- 
log med andre hvor man klargør sit eget synspunkt og derved øger den feelles indsigt og forståelse af situationen. Udvikling af træningspladser for en systematisk italesættelse og udveksling af erfaringer med det daglige arbejde fører til en lærende omgang med arbejdet og til udvikling af såvel den enkelte medarbejder som af organisationen og dertil ikke mindst til udvikling af de metoder som anvendes i den daglige opgaveløsning. Der arbejdes med transfer mellem afdelinger, fora m.v. hvor det er 'læreprocesserne selv' der indføres og ikke alene resultater af den læring der har fundet sted. Dette måles i en forbedret evne til at løse opgaverne sammen.

Metoder/modeller der anvendes til at understøtte læring er:

- Refleksionsgrupper

- Etablering af mødepladser

- Udvikling af træningsarenaer

- 'Firkantsamtaler'

- Opbygning af en permanent overbygning i form af en udviklingsorganisation - skel mellem arbejdsorganisering og udviklingsorganisering

- Igangsættelse af læringsspiraler

„Firkantsamtaler“ er regelmæssige samtaler mellem nøglepersoner i organisationen. Deltagerne repræsenterer centrale personalegrupper og opgavetyper på plejehjemmet. Firkantsamtalerne er en del af en spirende udviklingsorganisation hvor rutiner og den sædvanlige måde at gøre tingene på står til diskussion. En nærmere beskrivelse af de enkelte tiltag findes i den mere udførlige case beskrivelse i bilagsdelen.

Det processuelt dynamiske i læringssystemet - læringsspiralen

Det processuelt dynamiske i den læring som foregår når medarbejdere veksler mellem arbejds- og udviklingsorganisationen i de forskellige mødefora o.a.s. består i at der gennem faserne: 1) italesættelse af praksis 2) afprøvning i handling 3) efterfølgende diskussion med evt. justering 4) ny afprøvning osv. igangsættes leringsspiraler i større eller mindre skala. 


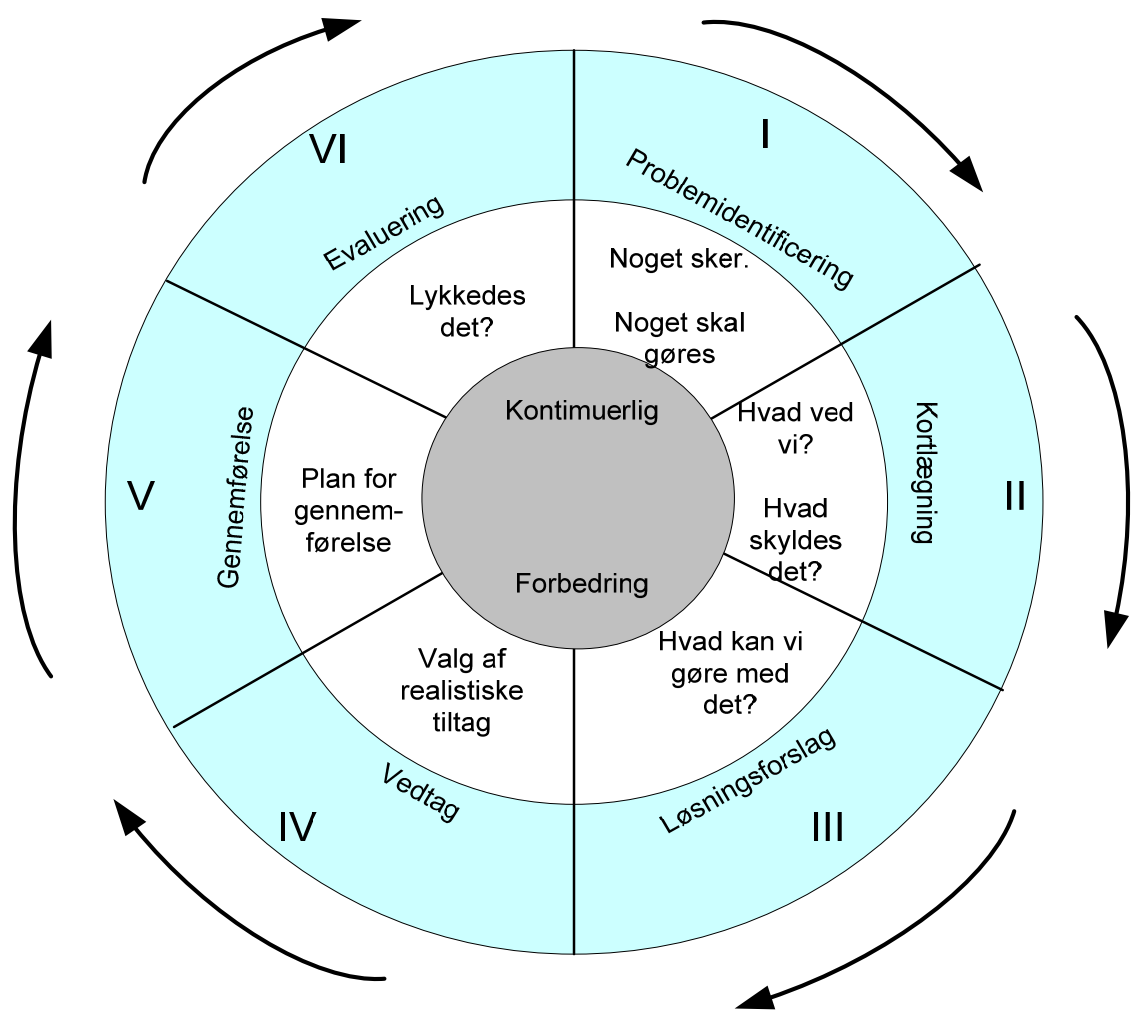

Figur. 1. Faserne i en laringsspiral

Eikeland og Berg 1997 p.57

Der tages udgangspunkt i praksis og i samspillet mellem formel og uformel læring. Det dynamiske i læringssystemet hvori læringsspiralen indgår finder sted som en udveksling:

- Mellem teoretisk læring og erfaringslæring

- Mellem individuel og kollektiv læring

\begin{tabular}{|l|l|l|}
\cline { 2 - 3 } \multicolumn{1}{c|}{} & Individuell læring & Kollektiv læring \\
\hline Teoretisk læring & $\begin{array}{l}\text { (1) Individuelle kurs, } \\
\text { boklesning og liknende }\end{array}$ & $\begin{array}{l}\text { (2) Forelesning / felles lyttning og } \\
\text { lesning }\end{array}$ \\
\hline Erfaringslæring & $\begin{array}{l}\text { (3) Læring gjennom hand- } \\
\text { ling: øvelse /trening / } \\
\text { tilvenning }\end{array}$ & $\begin{array}{l}\text { (4) Organisasjonslæring: fokusering } \\
\text { på felles praksis. Hvordan jobber vi } \mathrm{i} \\
\text { forhold til hverandre og i forhold til } \\
\text { opgaveløsning? }\end{array}$ \\
\hline
\end{tabular}

Figur. 2. Teoretisk læering og erfaringslæring

Eikeland og Berg 1997 p. 34 
Erfaringer viser at der ikke er noget principielt modsætningsforhold mellem individuel og kollektiv eller erfaringsbaseret og teoretisk læring, det drejer sig om at få de forskellige former for læring ind i et godt samspil.

I projektet arbejdes der overalt med eventuelle modsætningsforhold ved at omfunktionere og forvandle eller omscette dem til brugbare/frugtbare dynamiske felter for udvikling og læring herunder læringsog løsningsmodeller.

\section{Resultater og effekter}

I dette afsnit sammenfattes resultater af projektet herunder projektets egen vurdering af hvad der kom ud af det.

Alment

Casen er karakteriseret ved at der arbejdes med en række centrale faktorer til påvirkning af udbuddet af kompetence i virksomheden.

Anvendte faktorer som påvirker udbuddet af kompetence i virksomheden:

1. Kompetenceafklaring

2. Arbejdspladsforlagt uddannelse og kurser med certificering og med uddannelsespraktik på virksomheden

3. Mentor- og vejledningsordninger herunder seniorinstruktørordning

4. Seminarer og dialogkonferencer

5. Refleksionsgrupper, møde- og samtalefora

6. Opbygning og anvendelse af en permanent udviklingsorganisation herunder arbejde med afbalancering af arbejds- og udviklingsorganisationen

7. Organisationsændringer og ny ledelse

8. Deltagelse i udviklingsprojekter.

Der skelnes mellem formel læring som foregår i uddannelse med certificering, non-formel lering som finder sted i situationer der er organiseret med læring for øje men uden certificering og in-formel lcering som foregår i og omkring udførelsen af det daglige arbejde. Punkterne 1. og 2. omfatter formel laring punkterne 3., 4., 5. og 6. omfatter non-formel lering mens punkt 7. og 8. er eksempler på in-formel læering. En anden form for skelnen er organiseret lcering (omfatter situationer som er organiseret med læring for øje) og hverdagslcering (hvor dette ikke er tilfældet).

Alt holdes fortsat i bevægelse - en karakteristik af den (de) anvendte strategi(er)

Strategien i casen er karakteriseret ved: a) En flerhed/samtidighed af interventioner b) En systematisk anvendelse af disse samt ved løbende opfølgninger og igangsættelse af nye tiltag. c) Alt holdes fortsat i bevcegelse. Målet er at udvikle et permanent lceringssystem på arbejdspladsen 
baseret på medvirken fra alle i organisationen og med lceringsspiralen som gennemgående 'figur' i en strategi hvis endelige sigte er udvikling af en lcerende omgang med arbejdet.

I casen er al intervention praksisbaseret hvad enten det drejer sig om særligt tilrettelagte arbejdspladsforlagte uddannelses- og kursusforløb eller igangsætning af læringsspiraler omkring italesættelse, afprøvning og justering af metoder i den daglige opgaveløsning. Modeller (til problemløsning) udvikles over alt inden for et dynamisk 'søgefelt' som holdes i spænd af en løbende udveksling mellem læringens formelle og uformelle sider. Casen og den anvendte strategi herunder den mangeplanethed (multilayered) eller en flerhed og samtidighed af interventioner som karakteriserer casen er med til at klargøre hvor komplekst et felt anvendelsen af 'arbejdspladsen som læringsarena'er. Herved tydeliggøres eksempelvis også det forhold at resultater og effekter ikke udspringer af enkeltfaktorer, men derimod opstår og udvikles i et samspil af faktorer der igen varierer med organisationens indre og ydre kontekst.

Fremgangsrige strategier - hvad spiller ind?

Et vigtigt resultat af senior- og livsfaseprojektet som er beskrevet i denne case er udvikling af metoder og modeller til at arbejde med og understøtte læring på det individuelle og det organisatoriske plan. Konkrete initiativer og resultater som fremhæves af projektet selv er: Træeningsarena, seniorinstruktørkorps, bedriftsintern hjelpeplejerskole, klinisk kompetencestige, firkantsamtaler og refleksionsgrupper som en del af udviklingsorganisationen (Eikeland 2006). Endvidere fremhæves de forskellige uddannelsestiltag som blev iværksat som opfølgning på den kompetenceafklaring der fandt sted i projektet. ${ }^{12}$

Strategier som læringsbaserede løsninger på konkrete problemstillinger I casen finder modeludviklingen sted primært som en 'søgen' efter læringsbaserede løsninger på konkrete problemstillinger i samspillet mellem formel og uformel læring. Dette foregår på mange forskellige planer eksempelvis ved at undervisningen tilrettelægges erfarings- og praksisbaseret eller i forbindelse med lærings- og mødefora hvor rutiner og metoder i det daglige arbejde bliver diskuteret. Helt centralt i satsningen på at rette plejehjemmet op står to forhold: 1) Strategien om formel kompetenceudvikling gennem etablering af virksomhedsforlagt uddannelse som er praksis- og erfaringsbaseret og 2) Strategien om uddannelsespraktik på egen arbejdsplads og om praktikvejledning gennem indførelse af instruktørordning som oplærings- og mentorfunktion. Tilsammen udgør de to

\footnotetext{
${ }^{12}$ Det drejer sig konkret om udarbejdelse af modeller for modtagelse af sygeplejestuderende i samarbejde med Højskolen i Oslo, temakurser som introduktionskursus for alle ansatte (8 stk.), 40 timers grundkursus i pleje og omsorg for ekstravagter og vikarer i små stillinger, videreuddannelse af hjælpeplejere i geriatri og psykiatri og med kollegavejledning og ressourcegrupper nedsat på tværs af afdelinger samt opkvalificeringskurser for arbejdsledere samt oplering for ansatte i nyt datasystem.
} 
indsatsområder et felt på tværs i organisationen som etablerer et basalt udvekslingsforhold mellem den formelle og uformelle læring. Gennem etablering af en 'multilayered' strategi - bestående af en på én gang samtidighed og flerhed af interventioner - der alle er baseret på ovennævnte udvekslingsforhold - og ved at bygge videre på forudgående interventioner og på eksisterende fora (rettet mod omfunktionering) - lykkes det for projektet 1) at opretholde dette udvekslingsforhold som et dynamisk felt i organisationen og 2) at agere i det. Ikke 'til fulde' og ikke uden 'knaster' og 'modhager' men dog alligevel. ${ }^{13}$ Dette er - foruden de delresultater som kan opregnes og som projektet selv fremhæver - overordnet set det bæredygtige resultat som alle delresultater hviler på.

\section{Delresultater - fremhcevet af projektet selv ${ }^{14}$ :}

I 2003 blev Langerud plejehjem tildelt en hæderspris som „Utmerket læringsarena“ primært for intiativerne bedriftsintern hjælpeplejeruddannelse og seniorinstruktørordningen men også for at være lykkes med at omdanne plejehjemmet til en attraktiv arbejdsplads hvor medarbejderne gerne vil være og ønsker at blive. Denne anerkendelse af plejehjemmets bestræbelser var med til at sætte plejehjemmet på landkortet som læringsorganisation og som lærende virksomhed.

Af resultater fra forsøgsuddannelsen bedriftsintern hjcelpeplejeruddannelse (BIH) fremhæves at alle 15 deltagere har fået en formel uddannelse og at dette har givet mod på yderligere kompetenceudvikling også hos minoritetssproglige deltagere. ${ }^{15}$ Der er også tale om ændrede attituder og forestillinger hos deltagerne som læringsresultat. ${ }^{16}$ Arbejdspladsforlagt undervisning vurderes som en god mulighed for at lcere og samtidig få løn for det, men også det at de kan være i uddannelse sammen med andre voksne kollegaer (Folkeborg, Skog Hansen 2003). Det vurderes at projektet vil have stor overføringsværdi for pleje- omsorgssektoren (Ibid) og der er efterfølgende taget beslutning om at videreføre uddannelsen og at fastansætte projektlederen.

Seniorinstruktørordningen er som strategi et eksempel på en bevidst og vellykket rekrutterings- og fastholdelsesstrategi gennem anvendelse af medarbejdernes viden og erfaringer i oprettelsen af specialfunktioner, der kombinerer mentorfunktionen med det seniorpolitiske instrument (Eikeland, 2006). I projektet har i alt 7-8 hjælpeplejere arbejdet som seniorin-

\footnotetext{
${ }^{13}$ En grundig diskussion af projektets styrker og svagheder findes i Eikeland 2006.

${ }^{14}$ Ved 'projektet selv' forstås her primært forskningsresultater fra de to forsknings evalueringer af projektet som casen bygger på men det kan også indbefatte projektets aktører, herunder eksterne og interne projektledere og ansatte på plejehjemmet som jeg har interviewet (i juni-juli 2006).

${ }^{15}$ To af de minoritetssproglige deltagere har faste stillinger efter endt uddannelse mens to andre vil videreuddanne sig inden for sundhedsfag.

${ }^{16}$ Eksempelvis som at de minoritetssproglige oplever inkludering og at de er blevet langt bedre til sprog især det skriftlige og dette står helt central i oplevelsen af nytte og følelsen af større tryghed i arbejdet. Der er også dilemmaer så som at det er svært at komme til teoriundervisning når der mangler vikarer.
} 
struktører med ansvar for 6 måneders oplcering i grundlæggende pleje og omsorg for i alt 50-60 hovedsagelig fremmedsproglige praktikanter. Som et vigtigt læringsresultat herunder som effekt gennem projektdeltagelse fremhæves at seniorinstruktørerne giver udtryk for oplevelsen af „empowerment“. Defineret som: „En larings- og utviklingsprocess som øker folks (individ, gruppe, samfunn) kontrol over faktorer som oppfattes betydningsfulle for egen helse og livskvalitet“ (LHA I: Eikeland 2006). Dette læringsresultat handler blandt andet om at arbejdspladsen er udformet og organiseret på en sådan måde at der gives tilladelse og opmuntring til medarbejderne om at kunne gøre det som man finder rigtig i situationen. ${ }^{17}$ En seniorpolitik må derfor tage udgangspunkt i at celdre medarbejdere gennem et langt arbejdsliv har udviklet måder at holde sig selv og produktionen oppe på. At synliggøre og fremme dette aspekt kræver en udvikling i arbejdslivet der åbner for generationen af ældre arbejdstagere. (LHA I: Eikeland 2006). At projektet skabte forståelse for denne sammenhæng er et vigtigt læringsresultat.

Ifølge sygehusledelsens egen bedømmelse var følgende senior- og livsfasetiltag de vigtigste:

- Funktionen som seniorinstruktør blev videreført (oprettet i 2001). ${ }^{18}$

- Der blev åbnet mulighed for afdelingsbytte for de ansatte til forebyggelse og reduktion af nedslidning.

- Der blev åbnet mulighed for reduceret arbejdstid med fuld løn for ansatte over 62 år.

- Der blev åbnet mulighed for forskudt arbejdstid i forbindelse med børnepasning og andre livsfasebehov.

Seniorinstruktørordningen er siden indført som permanent ordning på plejehjemmet.

Andre resultater som kan nævnes er:

- At plejehjemmet fik løst sine rekrutteringsproblemer og hævet sin status og anseelse såvel eksternt som internt. Efter projektets ophør er der den faglige kompetence som plejehjemmet behøver og arbejdspladsen sørger selv for at dette opretholdes fremover gennem fortsat løbende afklaring og udvikling af personalets kompetencer.

- At der blev etableret en udviklingsorganisation som en permanent opbygning og opnåelsen af en bedre afbalancering af arbejds- og udviklingsorganisation ved at der veksles mellem de to former.

\footnotetext{
${ }^{17}$ Praktikanterne kan dog føle sig i en vis klemme over for instruktøren der som vejleder udtaler sig om hvorvidt deres kompetencer er tilstrækkelige.

${ }^{18}$ Som modvægt til en lidt for stor selvstændighed i seniorinstruktørgruppen ønskede ledelsen en rullende ordning hvor funktionen gik på skift mellem medarbejderne, men det var instruktørerne selv imod fordi de nu havde opnået en vis kompetencemæssige specialisering som de ikke ønskede at komme ud af igen ved at gå tilbage til ordinær pleje.
} 
Igangsætning af systematisk træning i „å mestre den erfarings- og organisjasionslcering som etterstrebes“" (Eikeland, 2006 p.65).

- Anvendelse og omfunktionering af eksisterende fora med henblik på at skabe læring. At der blev oprettet mødepladser, firkantsamtaler og refleksions- og udviklingsorganisering på afdelingsniveau til fremme af løbende dialog (omkring arbejde, opgaver og udførelse) som et resultat i sig selv og til opbygning af et læringssystem. Udvikling af evnen til at føre en dialog med andre herunder evnen til at klargøre eget synspunkt med henblik på at øge den fælles indsigt. Udvikling af dialogisk kompetence og det at lære af hinanden gennem dialog om opgaver. At få forskellige livsfase- og seniortemaer frem som grundlag for yderligere tiltag. Firkantsamtalerne bliver fra ledelseshold anset for at være helt centrale. Hensigten med dem er at skabe kernefelter hvor forskellige mødepladser på plejehjemmet kommunikerer med hinanden på en systematisk måde. Ud af firkantsamtalerne kom en samlet liste op over de ting, der er blevet diskuteret og denne liste bliver videregivet til ledelsen på plejehjemmet. Ideen med samtalerne er, at de forskellige personalegrupper skal lære af hinanden ved at udveksle erfaringer om arbejdet med opgaverne, men på et vist alment niveau sådan at metoderne bliver diskuteret og ikke alene driftsspørgsmål. For eksempel viser resultaterne fra mødefora og refleksionsgrupper at der er en tendens i retning af at ville bruge samtaler til løsning af driftsspørgsmål, og at den åbne diskussionsform på møderne er uvant i et system hvor de ansatte er vant til at arbejde på baggrund af instrukser. Samtidig ses det at deltagerne bliver stadig bedre til selv at strukturere og at tematisere rutiner, sætte dagsorden, føre referat, følge sager op, sende dem videre o.l. . Dette resulterer i en forbedret evne til at løse opgaver sammen (videndeling, erfaringsudveksling m.v.)

- Indføring af et lceringssystem som omfatter en bevidst og systematisk brug af samspillet mellem formel og uformel læring, teori og praksis, individuel og organisatorisk læring. Det var hensigten at gøre firkantsamtalerne permanente efter at AFI havde trukket sig ud. AFI's deltagelse i firkantsamtalerne skulle danne overgang til en bredere medvirken fra alle ansatte på plejehjemmet under opbygningen af et læringssystem der omfattede hele institutionen. Der skulle i højere grad satses på organisatorisk læring med dialogisk fælles refleksion over egen praksis baseret på deltagelse af alle afdelinger. I praksis blev der dog kun ressourcer til at satse på at skabe systemer for fælles refleksion og læring på enkelte afdelinger for senere at udbrede dette til andre afdelinger. Dette skulle blandt andet ske gennem i gangsættelse af læringsspiraler.

- Projektet bidrog til at hæve virksomhedens anseelse - internt og eksternt. Der blev frem for alt skabt en god uddannelses- og (op-) læringskultur som er udviklingsrettet og hvor alt til stadighed er i 
bevægelse - en læringsvilje, dette og tillid mellem ledelse og ansatte er vigtige veje frem i arbejdspladslæring. Virksomhedskulturen respekten fra de ansatte over for virksomheden, respekten udefra. Image forbedret gennem indsatsen for medarbejderne for helheden i virksomheden for de syge og brugerne, at man viser man vil noget med arbejdspladsen. Vcerdimcessigt skabtes øget legitimitet for virksomheden hos de ansatte. Inkluderende arbejdsliv baseret på dialog om erfaringer med det daglige arbejde. Arbejde med fælles forståelse og medvirkning. Seniorinstruktørordningen på plejehjemmet blev genstand for megen medieomtale i Norge og seniorinstruktører blev interviewet om ordningen. Endelig gjorde projektet den erfaring at senior og livsfasepolitik må integreres i en lærings- og udviklingsstrategi for hele arbejdspladsen, dvs. at flere typer af politik må arbejde sammen.

- Betydningen af forandringsagenter og ildsjcele påvises på mange måder i dette projekt. Gennem forskningsinstitutionens AFI's rolle i udviklingsprojektet bibragtes et 'udefra-blik' på det virksomhedsinterne til igangsætning af læreprocesser ved at stille: „kvalificerede systematiske spørgsmål til processer m.v. som ellers ikke ville blive stillet" (Eikeland 2006). Og dermed en støtte til ledelsens og de ansatte bestræbelser på at opbygge plejehjemmet som en lærende organisation og som læringsinstitution.

- Visionen om en lerende organisation er stærkt knyttet til lederskabet. På plejehjemmet blev der arbejdet med dette tema eksempelvis gennem forankring af projektet hos ledelsen og AFI’s støtte til ledelsen gennem tilrettelæggelse af ledelsesmøder med henblik på læring. Gennem organisationsændringer på plejehjemmet blev der arbejdet med ledelsen med mere synlig ledelse der lytter til forslag til ændringer fra medarbejderne og hvor hjælpeplejerne som central medarbejdergruppe får ledelsesansvar samtidig med at de løser hidtidige opgaver. Derved skabes mulighed for ledelsesmæssig opmærksomhed på den fond at viden og erfaring i organisationen som skal aflyttes og anvendes konstruktivt. Der blev også arbejdet med mere kommunikation på tværs af organisationen gennem ny organisationsstruktur, og der blev ansat ny ledelse med anden baggrund. I dag har chefen for plejehjemmet pædagogisk baggrund hvor det tidligere har været chefer med sygeplejefaglig baggrund. Med Projekt Langerud udviklede plejehjemmet sig fra at være en hierarkisk drevet organisation med tunge beslutningsveje og manglende kompetence til en organisation med fladere struktur med korte beslutningsveje og med kompetenceudvikling som et bevidst satsningsområde. „A virkeliggjøre visjonen om å bli en lærende organisasjon handler om organisasjonslæring og om hva som skal til for at en organisasjon lerer. Men det handler også om hvordan der kan organiseres permanente lceringsprocesser $i$ de ulike avdelingerne“ (Langerudveven, 2003 p.9). Ifølge den nu- 
værende leder er plejehjemmet i kraft af den samlede intervention og det der blev bygget op på vej mod at virkeliggøre en vision om at blive en lærende organisation, hvor læring vil foregå på alle planer og omfatte alle ansatte.

\section{Opsummerende}

Seniorløsninger, livsfase og organisatorisk læring - forebyggelse og inkludering (alder, fremmedsproglighed m.v.) - tilpasning af arbejdet til medarbejdernes livssituation og behov. Bedre trivsel og bedre anvendelse af ældre medarbejderes særlige kompetencer. Kompetenceudvikling rummer ofte en indre modscetning - den kan være tilpasnings- og udviklingsorienteret eller den kan være funktionel og disfunktionel. Igennem projektet erfares det at det der opnås altid har flere sider - ikke alene forstået som en plus-minus-side men snarere eller også som en dobbelthed/flersidethed i form af et spænd eller som et dynamisk felt der har flere sider i sig som organisationen må lære at 'huse' eller rumme og arbejde med og anvende konstruktivt. Foruden en række af de nævnte ændringer var det et centralt læringsresultat at der blev skabt interesse i at opbygge en lærende organisation/læringsinstitution og der er skabt en grundholdning om at organisationen vil lære. Strategiens flerstrengethed og dens evne til at bygge videre på det der allerede er i gang på plejehjemmet og til at følge op og holde tingene i bevægelse er med til at lægge perspektivet i strategien: Fra seniorinstruktører til læring for alle - etablering af sammenhænge, bevægelse/bevægelighed og retning gennem anvendelse af læringsstrategi - mod et inkluderende arbejdsliv.

\section{Referencer}

Eikeland Olav og Anne Marie Berg (1997): Medvirkningsbasert organisasjonslæring og utviklingsarbeid i kommunene. Oslo. Kommuneforlaget.

Eikeland Olav, Liv Hanson Ausland m.fl. (2006): Har systematisk læring på arbeidsplassen noe med livsfaseog seniorpolitikk å gjøre? Rapportering fra Forsøks- og Utviklingspro- sjektene i Nasjonalt Krafttak for seniorpolitikk i arbeidslivet (2001-2005). Folkenborg Kari og Inger Lise Skog Hansen (2003): Bedriftsintern hjelpepleierutdanning. I: Arbeidsplassen som læringsarena for Minoritetsspråklige arbeidstakere. Oslo. Fafo.

Langerud Sykehjem (2003): Langerudveven. Rapport om Projekt Langerud 2000-2002. 



\title{
6. Analyse af cases: Hvad karak- teriserer de effektive strategier? Beskrivelse af fem modeller
}

\author{
Hvordan kan best practice beskrives? Niveauer for \\ beskrivelse af best practice
}

Best practice kan i denne sammenhæng beskrives på tre niveauer:

Niveau 1: Komplekse pcedagogiske strategier:

Analyserne af casene peger på, at der ikke er en enkelt, men flere forskellige pædagogiske strategier der fremstår som succesfulde i den forstand, at de viser en positiv og ønsket effekt, fører til realisering af opstillede mål for projektet.

Best practice kan altså beskrives som en række komplekse organiserede aktiviteter - pædagogiske strategier og -metoder.

Niveau 2: Strategibcrende faktorer. Succesfaktorer tilknyttet en specifik strategi

Inden for hver at de komplekse strategier søger vi at analysere os frem til mere specifikke faktorer inden for strategien - f.eks. ledelsens betydning - der ser ud til at være bærende for at strategien fungerer succesfuldt. Succesfaktorerne er her specifikt knyttet til en bestemt strategi. Vi kalder dem strategibærende faktorer.

\section{Niveau 3: Generelle succesfaktorer}

Her forsøger vi at se om der er faktorer der fremstår som mere generelle succes faktorer i den forstand at disse faktorer ikke kun optræder inden for én strategi, men genfindes - måske i lidt forskellige varianter - i forskellige strategier. Disse faktorer har således en mere general karakter.

Niveau 1: Komplekse predagogiske strategier:

For at kunne beskrive og sammenligne strategierne og fremdrage væsentlige forskelle og ligheder i strategierne, har vi udarbejdet en måde at kategorisere strategierne på. 
Vi arbejder i denne forbindelse med to dimensioner, der sammenholdes med hinanden, således at der fremkommer en matrix med 4 kategorier:

- 1. dimension: Sstrategiens fokus, hvad skal udvikles: _Tto kategorier: individ resp. organisation

- 2. dimension: uddannelsesform. To kategorier: curriculum based resp. practice based. Vi kan her også tale om to forskellige uddannelses logikker.

1. dimension er et kontinuum med to yderpunkter: individ resp. organisation.

I den individorienterede strategi er målet, at skabe forandringer i individet, typisk udvikling af individets kompetencer. Hvilke typer af kompetencer er det hensigten at udvikle og hvilken kompetenceudvikling finder faktisk sted?

I den organisationsorienterede strategi er målet at understøtte udviklingen af sociale processer og organisatoriske forhold, f.eks. udvikling af relationer mellem individer, udvikling af teams, udvikling af arbejdsorganiseringen, ændring af forhold i arbejdet mv.

I dette regi - arbejdspladslæring - kan de to mål typisk være forbundet i en mål-middel relation: den individuelle udvikling er middel til social/organisatorisk udvikling, og organisatorisk udvikling kan som et blandt flere mål have at understøtte individers læring og udvikling. Aktiviteterne i strategien kan så overvejende fokusere på eller have udgangspunkt i et individ- resp. organisatorisk niveau.

Dette fører til opstilling af følgende ideal-type model, en matrise med 4 kategorier:

Ideal-type model:

\begin{tabular}{lll}
\hline Dimensioner & Individ & organisation \\
\hline Curriculum based & $\begin{array}{l}\text { (1) Skolemodel: } \\
\text { Den pensumorienterede skole }\end{array}$ & (2) Efteruddannelse \\
Practice based & (3) Lærlingemodel & (4) Organisationsudvikling \\
& On-the-job-training & Organisatorisk læring \\
\hline
\end{tabular}

På denne baggrund kan vi sige, at der findes fire idealformer af strategier, der udgør elementer i arbejdspladslæring, hvor elementerne kan indgå i forskellige kombinationer i de konkrete aktiviteter.

(1) Kategori. Skolemodellen. Strategiens mål er at skabe forandringer i individet, typisk udvikling af individets kompetencer. Der tænkes i curriculum termer, dvs. formuleret mål, anvendelse af fag, udarbejdet læseplan, etc. Læringsmål og behov er defineret i curriculum, evt. i relation til de enkelte deltageres behov.

(2) Kategori. Efteruddannelse. En arbejdsplads sender en del af dens medarbejder på kursus. Den kompetenceudvikling der skal finde sted er 
middel til at støtte arbejdspladsens realisering af mål. Undervisningsmål og -behov er formuleret i curriculum, evt. med udgangspunkt i arbejdspladsens og deltagernes behov.

(3) kategori. Lcrlingemodellen. Formålet er at kvalificere en person gennem en oplæring i praksis på arbejdspladsen.

(4) Organisationsudvikling. Formålet er her at gennemføre en ønsket, planlagt og systematisk udvikling af den organisatoriske side af arbejdspladsen. Organisationsudvikling behøver ikke indbefatte uddannelse/undervisning, men mange strategier for arbejdspladslæring knytter an til en samtidig eller efterfølgende udvikling af arbejdspladsen som organisation.

Når vi ser på de konkret anvendte metoder/strategier i casene, dvs. i „virkeligheden“ vil disse strategier ofte overlappe, og ligger over grænserne for de fire kategorier. En konkret strategi kan være placeret i matrix-feltet så den indeholder elementer af alle 4 idealmodeller.

For de konkrete cases gælder, at nogen cases indeholder beskrivelsen af en enkelt strategi. Andre cases indeholder beskrivelser af flere strategier, en kombination af forskellige strategier. Og de samme grundtyper af strategier kan - med mindre forskelle og nuancer - indgå i flere cases.

Fra vores case materiale har vi fremanalyseret flg. strategier/metoder, der kan karakteriseres som best practice i forhold til vores system af idealtyper:

\section{Model 1: Etablering af en udviklingsorganisation uden for arbejdspladsen, og samtidig i samspil med arbejdspladsen}

Best practice: Undervisning som arbejdsplads intervention

Denne organisering af best practice er i vores idealtypemodel placeret i felterne: skolemodellen, efteruddannelse og organisationsudvikling.

Modellen indeholder et kursusforløb med medarbejdergrupper, hvor arbejdserfaringer formuleres, analyseres og belyses teoretisk af fagets teorier, og hvor efterfølgende beslutninger fra kursusforløbet - med baggrund i analyser og teoretiske perspektiveringer - vedrørende ønskede udviklinger på arbejdspladsen, implementeres på arbejdspladsen med ledelsens støtte.

Modellen indeholder således et fire fase forløb for kompetenceudvikling af medarbejdere:

(1) En indledende tilrettelceggelsesarbejde af kompetenceudviklingen, hvor det er væsentligt at de forudsætninger som kompetenceudviklingen bygger på ikke er isolerede individualistiske forudsætninger, men er arbejdspladsrelaterede. Kompetenceudviklingen indeholder som sit første trin en undersøgelse af arbejdspladsen: dens udviklingsbehov, problemer, særlige situation osv. Der er en kobling til det individuelle plan derved at 
medarbejderne formulerer mål for forandringer på arbejdspladsen, som de ønsker, ønskede ændringer i deres arbejde.

(2) Gennemførelse af et kursusforløb. Kursusforløbet kan fysisk placeres på arbejdspladsen eller uden for, på uddannelsesinstitutionen. Det kan placeres i eller uden for arbejdstiden, det mest hensigtsmæssige for læreprocessen er at det er placeret uden for arbejdspladsen.

Kan der skabes kompetenceudvikling alene ved hjælp af kursusforløbet? Det afgørende svar er her nej, fordi en erhvervet kompetence indebærer at individet kan handle, anvende sin viden til at handle i mødet med arbejdets krav. (Udvikling af f.eks. sociale og kommunikationskompetencer kan dog finde sted i dette felt). I det væsentlige kan der på kurset skabes forudscetninger for kompetenceudvikling: Der skabes ny viden hos medarbejderne, ved at integrere to vidensformer: På den ene side almen og teoretisk viden (skolastisk viden), i dette tilfælde om kommunikation og samarbejde, og på den anden side den praktiske-faglige viden, som deltagerne møder med på kurset. Men kompetence er som nævnt mere end viden, og kompetencer udvikles ikke alene gennem tilegnelse af almen og faglig viden. Kompetencebegrebet indeholder en anvendelsessituation: For at viden kan blive til kompetence, skal den udfordres, anvendes og udvikles i erhvervspraksis/arbejdspraksis. Denne anvendelse af viden planlægges på kurset, og realiseres efterfølgende på arbejdspladsen i en opfølgning.

(3) Implementering af forandringstiltag på arbejdspladsen. I denne fase føres de planer, der er udarbejdet under kurset og som indeholder initiativer til forbedringer på arbejdspladsen, ud i livet. Fasen her lægger op til handling i læreprocessen, handling i praksisfeltet. Disse handlinger implicerer en påvirkning og forandring af de sociale/organisatoriske processer på arbejdspladsen.

(3) Follow up. Sidste trin i kompetenceudviklingsmodellen er opfølgning. Deltagerne har fået lejlighed til at handle og løse problemer i praksis, i arbejdssituationen. En opfølgning kaster lys over, hvordan det er gået med at anvende den erhvervede viden og føre planerne om udvikling af arbejdspladsen ud i praksis. Follow up er en feed-back proces og en væsentlig læringsbetingelse i relation til både individuel laring (kompetenceudvikling) og organisationsudvikling (organisatorisk læering).

Formuleret anderledes betyder dette, at strategien indebærer, at der skabes en midlertidig udviklingsorganisation (kursus) uden for arbejdspladsen. Udviklingsorganisationen griber altså i første omgang ikke ind i og forstyrrer eller påvirker arbejdspladsens daglige funktioner og rutiner. (Den forstyrrer og påvirker lidt og uintenderet ved at der i nogle tidsperioder, trækkes medarbejdere ud af produktionen og daglig ledelse, for at deltage i kurset).

I udviklingsorganisationen arbejdes med i første række at formulere og analysere arbejdspladserfaringer og -problemer. Erfaringer og problemer sættes i teoretisk perspektiv ved at anvende teorier fra et fag. I anden række 
formuleres - på baggrund af analyserne af arbejdspladserfaringerne - mål for forandringer og forbedringer på arbejdspladsen, som medarbejdere og ledelse kan blive enige om, og der udarbejdes planer for hvordan disse planer om forandringer kan implementeres på arbejdspladsen.

På kurset skabes forudsætningerne for kompetenceudvikling: Der skabes ny viden hos medarbejderne, ved at integrere to vidensformer: På den ene side almen og teoretisk viden (skolastisk viden), i dette tilfælde om kommunikation og samarbejde, og på den anden side den praktiskefaglige viden, som deltagerne møder med på kurset.

Set i dette lys, at strategien handler om at etablere en midlertidig udviklingsorganisation, og et efterfølgende samspil mellem udviklingsorganisationen og arbejdspladsen (hvorefter udviklingsorganisationen ophører med at eksistere), kan hovedtræk i strategien siges at være:

Etablering af udviklingsorganisationen

- Der etableres et samarbejde mellem arbejdspladsen og en uddanneIsesinstitution, f.eks. et voksenuddannelsescenter, herunder et samarbejde med én eller flere lærere fra institutionen, der har de nødvendige kompetencer.

- Der planlagges og gennemføres kursus for en større og samlet gruppe af medarbejdere på arbejdspladsen, f.eks. hele gruppen af medarbejdere i produktionen. Nærmeste ledelse deltager også.

- Det fysiske regi hvor kurset afholdes kan både være på arbejdspladsen (arbejdspladsforlagt undervisning) eller uden for arbejdspladsen, på en uddannelsesinstitution.

- Den faglige og teoretiske ramme om kurset er et bredt og alment fag, f.eks. som i casen faget „Kommunikation og samarbejde“.

- Kursustilrettelæggelsen. Her er følgende forhold vigtige: Virksomhedens overordnede ledelse og medarbejdere samarbejder om at udforme rammerne om kurset. Rammerne drejer sig om kursets formål, tidsmæssige længde og -placering, deltagere, samt hovedtræk af indhold og undervisningsformer. Det er væsentligt at der i målformuleringen indgår mål der angiver ønskede forbedringer af arbejdspladsen. Der kan ligeledes indgå mål om individuel kompetenceudvikling, f.eks. udvikling af kommunikationskompetence, mv.

- Som grundlag for kursustilrettelæggelsen gennemføres en undersøgelse af arbejdspladsen. Det er væsentligt at det er arbejdspladsforudsætningerne der er de pædagogiske forudsætninger for realiseringen af arbejdspladslæringen efter dette koncept.

Arbejdet i udviklingsorganisationen

- Når medarbejdere og nærmeste ledelse medvirker på kurset er de trukket ud af de daglige rutiner på arbejdet. De bliver ikke forstyrret af kontakter, krav og problemer fra arbejdet, og de kan således koncentrere sig om arbejdet i udviklingsorganisationen. De enkelte del- 
tagere bærer naturligvis psykisk deres arbejdsmæssige rolle, position, ansvar med videre „i baghovedet“, men mødes i en anden social struktur, med dialog og diskussion „rundt om bordet“.

- Selv om der er tale om et kursus, der bygger på et fag eller et teoretisk fundament, er det ikke meningen at faget/teorien skal læres isoleret,. Ddetr er formålet at anvende faget til at understøtte en organisatorisk forandringsproces på arbejdspladsen.

- Dette realiseres ved at udviklingsorganisationen fungerer som et refleksionsum, hvor erfaringer kan formuleres og perspektiveres teoretisk. Et vigtigt forhold i deltagernes læreproces er sammenhængen mellem teori og praksis. Der søges skabt en integration af teori og praksis, en integration af de to vidensformer - almen viden og faglig/ erhvervsrettet praksisviden - ved:

- At arbejde både induktivt og deduktivt. Induktivt betyder at udgangspunktet er konkrete erfaringer, der formuleres, sammenlignes og analyseres. Herefter relateres de konkrete erfaringer til almene begreber, og det erfaringerne ses som konkrete manifestationer af mere generel teori, der præsenteres. At arbejde deduktivt betyder at der tages udgangspunkt i abstrakte begreber og teorier, der herefter illustreres og belyses gennem konkrete erfaringer. Begreber og teori er redskaber til at undersøge og forstå praksis. I dette arbejde skal læreren konstant skabe forbindelse mellem teorien og kursisternes arbejdsliv/hverdagsliv, bl.a. via eksempler og dialog omkring disse.

- Der arbejdes med casemetoden som undervisningsmetode. Lærerne præsenterer cases der belyses ud fra teori der er formidlet. Endvidere arbejdes med øvelser hvorigennem der skabes erfaringer i selve kursussituationen og tilvejebringes muligheder for at handle og få feed-back. Der frembringes et konkret erfaringsmateriale der kan gøres til genstand for undersøgelse og teoretisk perspektivering. Der arbejdes med en vekslen mellem lærerstyret og deltagerstyret undervisning.

- Der arbejdes med en dialogbaseret undervisning, aktiverende undervisning og gruppeundervisning, hvor gruppen både udgør et læringsmiljø og et redskab til problemløsning og planlægning.

- Der arbejdes grundlæggende med medarbejderinvolvering på mange niveauer og i alle faserne fra udviklingsprojektets start til den afsluttende follow up. Medarbejderinvolvering er vigtig, af flere grunde. Dels udløser involvering „commitment“, dvs. engagement og forpligtelse over for de planer og ideer man har med at gøre, dels betyder medarbejderinvolvering at medarbejdernes erfaringer og ekspertise inddrages i udviklingsprojektet som ressourcer. Hertil kommer at medarbejderindflydelse er kendt som en vigtig faktor i det psykiske arbejdsmiljø og en faktor af positiv betydning for arbejdsmiljøet som læringsmiljø. 
- En løbende side af arbejdet drejer sig om at skabe og vedligeholde motivationen fra deltagernes side. Motivation skabes gennem medarbejderinvolvering. Ligeledes er det vigtigt i projektets start at skabe succesoplevelser som grundlag for det videre arbejde. En vigtig faktor i motivationen er, at læringen ikke af deltagerne opleves som teoretisk og virkelighedsfjern, men at læringen tager udgangspunkt i deltagernes arbejdslivserfaringer og at der løbende skabes en nær kobling mellem teori og begreber på den ene side, og deltagernes konkrete erfaringer på den anden side. Et væsentligt element i motivationen er at deltagerne får medindflydelse på udviklingen af egen arbejdssituation og evt. virksomheden som helhed.

- Udviklingsorganisationen funger som et planlægningsforum, hvor der formuleres mål og planer for ændringer deltagerne ønsker gennemført på arbejdspladsen.

Forbindelsen mellem udviklingsorganisationen og arbejdsorganisationen Grundlæggende for modellen er, at afstanden mellem uddannelse og arbejde skal mindskes. Samtidig kan kontakten mellem udviklingsorganisationen og arbejdsorganisationen siges at være modellens akilleshæl. Kontakten etableres gennem en implementering af planerne fra udviklingsorganisationen, hvor ledelsens støtte er vigtig, og en senere follow up, hvor man sammen evaluerer, hvordan det er gået med at gennemføre de planlagte ændringer. Hvad er blevet gennemført og hvad er ikke blevet gennemført, og hvorfor? Hvad har støttet implementeringen og hvad har de vigtigste barrierer været? Hvordan kommer man videre i arbejdspladsens udvikling herfra? Afslutningsvis forankres kompetenceudvikling og organisationsudvikling på selve arbejdspladsen, hvorfra udviklingsprocesserne skal understøttes og videreføres.

Nogle væsentlige forudsætninger bag model 1.

Ny funktion for uddannelsesinstitutionerne og ny lærerrolle.

Uddannelsesinstitutionen bag læreren skal ændre funktion fra en leverandørrolle til en institution med ekspertise inden for feltet organisations konsultation. Førstnævnte funktion indebærer at institutionen har ekspertise mht. at have udviklet en række færdige kurser, der kan leveres hvis de efterspørges. Sidstnævnte ekspertise drejer sig om hvordan læreren som konsulent kan arbejde med en undervisning der er nært forbundet med arbejdspladsen. Læreren skal have indsigt i, hvordan arbejdspladsen kan anskues som en organisation. Læreren skal kunne gennemføre en undersøgelse af virksomheden med henblik på at kunne gøre arbejdsmæssige forhold til indhold i undervisningen. Læreren skal i undervisningen ikke formidle et fag, men anvende faget som instrument til at ændre den praksis, der udgøres af det daglige arbejde i virksomheden og virksomhedens arbejdsorganisering og kultur. Det kræver at læreren skal have en 
række kompetencer ud over undervisningskompetencer, nemlig kompetencer til at agere som organisationsudviklingskonsulent. Hvad angår undervisningskompetence skal læreren først og fremmest kunne arbejde fleksibelt med en tilpasning af undervisningen i forhold til arbejdspladsens situation og behov. Læreren skal også have kompetence til at arbejde med kursusdeltagere der både kender hinanden i forvejen, og som skal fortsætte med at fungere sammen i arbejdet på deres fælles arbejdsplads. En mulighed for at imødekomme dette omfattende kompetencekrav er, at arbejdet kan udføres af et team, der tilsammen besidder disse mangesidige kompetencer.

Nyt samarbejde mellem uddannelsesinstitutioner og virksomheder.

Det nye samarbejde er karakteriseret ved at det har fokus på rammerne om undervisningen og de overordnede mål for udviklingsprojektet. Der er endvidere et samarbejde om kortlægning af virksomhedens/medarbejdernes behov for kompetenceudvikling. Vigtigt i samarbejdet er det løbende samspil mellem udviklingsorganisationen og arbejdspladsen, der både viser sig tidligt i processen, med fastlæggelse af mål og rammer, og sent i processen med follow up på den planlagte implementering af forandringer på arbejdspladsen.

Model 1 er en kompleks strategi der udgøres af en udviklingsorganisation og dennes samspil med arbejdspladsen, hvor follow up er et vigtigt element.

\section{Strategibcrende faktorer}

- Med kombinationen af skolemodellen og organisationsudvikling skabes en sammenhæng mellem formel og informel læring, mellem teoretisk almen viden og deltagernes erfaringsbaserede og evt. tavse viden. Almen og faglig viden integreres.

- Der udvikles kompetencer gennem en integration af viden, holdninger og handling. Holdninger eksponeres og bearbejdes, og den udviklede viden og holdninger bringes til udfoldelse i den arbejdsmæssige sammenhæng.

- Strategien giver mulighed for handling fra deltagernes side.

- Strategien indebærer realisering af mange elementer i refleksion: deltagerne eksponerer deres viden, erfaringer og holdninger, sammenligner disse forhold, og ser dem ud fra forskellige teoretiske perspektiver. Det kognitive element i refleksion: Deltagere får lejlighed til at planlægge handlinger. Det anticiperende element i refleksion: Deltagerne får lejlighed til at handle og få feed-back på handlinger. Det handlingsorienterede og evaluerende element i refleksion. På denne måde udfoldes refleksionsbegrebet mangesidigt i modellen.

- Der er fra andre cases - f.eks. Keldsen A/S - gode erfaring med at indlægge en „eksperimenterende“ periode, når medarbejdere vender 
tilbage til arbejdspladsen fra kursus. Medarbejderen skal ikke lige træde ind i de banede stier og den gamle rutine, men skal have en periode med frihed til at prøve at anvende det lærte, ved at forholde sig lidt prøvende og eksperimenterende. På denne måde realiseres det eksperimenterende aspekt i refleksion.

- Strategien indebærer og forudsætter ledelsesstøtte, - og dette på forskellige niveauer i forløbet. Væsentligst er ledelsesstøtte i grænsefladerne mellem kursus og arbejdspladsen: ved etableringen af selve konceptet: undervisning som intervention på arbejdspladsen. At deltagerne får lejlighed til at anvende kurset som platform for udvikling af arbejdet. At ledelsen accepterer dette, sætter rammer herfor, og støtter disse implementeringsprocesser. Ledelsen har en vigtig funktion i at koordinere de forskellige tiltag til forbedringer, og sætte disse i relation til virksomhedens overordnede mål og strategi.

- Strategien indebærer at medarbejderne involverer sig i at undersøge og forbedre arbejdspladsen, og bruger deres ressourcer hertil. Medarbejderinvolveringen giver bedst resultat når den sker så tidligt som muligt og i alle faser af projektet.

- Strategien indebærer at ledelsen ser og anvender medarbejderne som ressourcer for udvikling af arbejdspladsen.

- Strategien bygger hele vejen igennem på dialog mellem medarbejdere og ledelse og medarbejderne indbyrdes.

- Strategien indebærer, at medarbejderne ret hurtigt i processen oplever en succes: en succes med denne måde at lære på, der er anvendt og succes mht. at opleve reel indflydelse

- Undervisningen er erfaringsbetinget, tager udgangspunkt i deltagernes erfaringer, herunder især erfaringer med arbejdet. Undervisningen er både induktiv og deduktiv i sin form og forløb.

- Undervisningen skal først og fremmest være fleksibel så den indordner sig efter de arbejdsmæssige forhold på arbejdspladsen.

\section{Effekter}

Set i forhold til idealmodellen er strategien karakteriseret ved at den kombinerer skolemodellen, efteruddannelsesmodellen og organisationsudvikling. I den studerede case, der modsvarer denne model er konstateret følgende effekter:

Effekter på et individuelt niveau:

- Medarbejderne udvikler et ønske om at præge arbejdspladsen

- Medarbejderne udvikler tillid til og forudsætninger for at kunne øve indflydelse på arbejdspladsen

- Medarbejderne har erhvervet sig en viden om arbejdspladsen der går ud over deres eget mere snævre arbejdsområde 
Effekter på organisationsniveau:

- Medarbejderne udvikler relationer til medarbejdere i andre dele af virksomheden

- Medarbejderne implementerer forbedringer i deres arbejde i organisationen

Model 2: Erhvervsbaseret læring (Yrkesbaserat lärande). Etablering af samarbejde mellem en uddannelsesinstitution og en arbejdsplads, hvor arbejdspladsens praksis er udgangspunkt for integration af praksisviden og teoretisk viden. Söderhamn modellen.

Denne model er først og fremmest tænkt i relation til de mest udsatte set i uddannelsesmæssig sammenhæng, personer med ingen eller meget begrænset uddannelsesmæssig baggrund, personer der er uddannelsesfremmede og evt. modvillige og med dårlige erfaringer i forhold til formaliseret læring, og evt. med en svag position på arbejdsmarkedet.

Princippet er at individet får et job og væver - , som det udtrykkes teori og praktik, og det er væsentligt at praktikken er forudsætningen for teorien. Modellen er en metode til at fremme livslang læring i praktikken. På det samfundsmæssige og institutionelle niveau er modellen baseret på et samarbejde mellem voksenuddannelsesinstitutioner, erhvervsliv og arbejdsformidling/job-centre (arbetsförmedling), hver med deres indbyrdes forskellige mål for deres virke.

„Sitting next to Nellie“ er et udtryk fra industrialiseringens barndom, hvor en sidemandsoplæring kunne tage 7 år, inden personen kunne arbejde selvstændigt. Med denne model er denne tid betydelig kortere, selv om de kompetencer der skal udvikles er betydelig mere komplicerede. I denne model tager praktikken 6-12 måneder og hertil kommer ca. 30\% teoretisk undervisning og vejledning, så sidemandsoplæringen er ændret på flere måder.

Når basis for læringen er praktik betyder dette ikke at der pædagogisk fokuseres snævert på ,job performance“. Det der skal læres - erhvervet opfattes som bestående af:

- Erhvervsskultur der står for traditioner og sprog inden for erhvervet/ branchen. Dette lærer man sig på arbejdspladsen

- Erhvervspraksis står for de regler og procedurer der kendetegner arbejdet

- Erhvervskundskab er alle former for kundskab

Modellen drejer sig om en fusion mellem erhvervsteori og erhvervspraktik, hvor deltagerne opdager at de behøver teori, gennem deres praktiske arbejde. Det er arbejdsopgaverne der bestemmer, hvad der er interessant $\mathrm{i}$ 
teorien. Der er af den tilknyttede uddannelsesinstitution udarbejdet en læreplan der anvendes sammen med erhvervstræning på arbejdspladsen. Det er erhvervsudførelsen der bestemmer, hvornår teorien skal behandles. Teori kan være teoretiske kurser eller delforklaringer af produktionen, med hjælp af pædagogiske vejledere. Et eksempel er at uddannelsen varer godt 12 måneder, hvoraf $70 \%$ er placeret i produktionen sammen med vejledere, og 30 \% teoretisk undervisning der forestås af erhvervslærere. Der gennemføres en validering der fører til en certificering, der kan anvendes på andre arbejdspladser.

Modellen indeholder det vekseluddannelsesprincip der er etableret i forskellig form i erhvervsuddannelsen i de nordiske lande, hvor teori og praksis integreres i læreprocessen, men hvor praksis er strukturerende for arbejdet med teorien.

I forhold til vores idealmodel bevæger denne model sig i felterne skolemodel og lærlingemodellen.

Strategibærende faktorer

- Modellen har som udgangspunkt praksislæring

- Modellen indeholder en integration af teoretisk læring og praksislæring, hvor sidstnævnte er strukturerende for den teoretiske læring

- Modellen indebærer mulighed for handling og praksisudøvelse med feed-back i en praksissituation

- Modellen indebærer anvendelse af en vejleder stil støtte for integrationen mellem praksislæring og teoretisk læring

- Modellen indebærer et samarbejde mellem en uddannelsesinstitution og en arbejdsplads, med store krav til uddannelsesinstitutionens fleksibilitet med at indrette den teoretiske formidling efter arbejdssituationen

Forskning i tilknytning til modellen fremhæver også en række svagheder eller problemer:

- Både erhvervsledere og vejledere var tilbøjelige til at arbejde med teori og praktik som adskilte størrelser, hvilket ikke er hensigten i modellen

- Vejlederne opfattede ikke sig selv som pædagoger

- Koblingen mellem vejledere og teoretiske kurser var ikke godt integreret

- „Överföringen av yrkeskunnande kännetecknades av att stå och titta på tills man sett momentet göras tilsträckligt många gånger.“

Forskningen viser altså, at det der er adelsmærket i modellen, at teori og praksis ikke holdes adskilt, er vanskeligt at realisere. Modellen er et forsøg herpå. 
Effekter

Modellen har vist sig effektiv mht. udvikling af erhvervskompetencer hos uddannelsesfremmede.

\section{Model 3: Medarbejderuddannelse gennem gap-analyse baseret på medarbejderdialog}

Hyppigt beskrevne negative erfaringer med kompetenceudvikling af medarbejdere - som denne model udgør et radikalt svar på - er, at uddannelsestilbud i form af færdige kursuspakker, ofte har vist sig ikke at modsvare virksomhedens behov. I disse tilfælde er der erfaringer for, dels at der bliver problemer med medarbejdernes motivation for at lære. Hertil kommer, at selv om deltagerne oplever at de lærer under et sådant kursusforløb, viser der sig ofte efterfølgende alvorlige problemer med at overføre og anvende den erhvervede viden i de konkrete arbejdssammenhænge.

Modellen er et svar på, hvordan der kan skabes en kompetenceudvikling der er nært forbundet med virksomhedens og medarbejdernes behov. Modellen indeholder på den ene side en klassisk gap-analyse, dvs. en analyse der sammenholder et billede af, hvilke kompetencer virksomhedens medarbejdere besidder i dag, med et billede af kompetencekravene i fremtiden. Forskellen mellem de to billeder udgør uddannelsesbehovet.

I modellen her er afklaring af virksomhedens kompetencesituation således grundlaget for uddannelsesplanlægning. Der udarbejdes en uddannelsesplan, som medarbejderne forpligter sig til at gennemføre. Arbejdet foregår i en dialog mellem ledelse og medarbejdere. De ansatte bidrager til en kortlægning af deres egne kompetencer gennem et forløb af diskussionsmøder. Projektet forudsætter engagement fra ledelsens side, både på et overordnet og et konkret plan. Overordnet for at deltagerne kan have tillid til projektet. Ledelsens engagement er særlig vigtig i et kompetenceudviklingsprojekt fordi et centralt omdrejningspunkt her er sammenhængen mellem organisationens mål og arbejdsprofilen for hver enkelt af de ansatte, og her er diskussion og samarbejde mellem ledelse og medarbejdere fundamental.

Strukturen i denne model kan skitseres således:

- Afklaring af virksomhedens kompetencesituation gennem en gap analyse

- Udarbejdelse af en forpligtende uddannelsesplan

- Realisering af uddannelsesplanen: kompetenceudvikling af medarbejderne 
Modellen forløber i følgende faser:

Planlægningsfasen

På et indledende møde mellem ledelsesrepræsentanter, medarbejderrepræsentant og forsker/konsulent træffes aftale om: kompetenceudviklingsprojektets sigte og mål, fremgangsmåde, herunder hvor stor en del af de ansatte der skal deltage, tidsplan og tilførelsen af de nødvendige ressourcer. Hele produktionsgruppen kan indgå i planlægningsfasen, der kan vare ca. $1 \frac{1}{2}$ år.

Sigtet er ved hjælp af en kompetencekortlægning at identificere de mest aktuelle kompetenceudviklingsbehov og at foretage en prioritering af behovene på uddannelsesområdet.

Information og valg af metode til kompetenceafklaring. Fordeling af arbejdsopgaver.

Der informeres til virksomhedens medarbejdere om mål og fremgangsmåde i projektet, og foretages valg af metode til kompetenceafklaring. Der findes her mange metoder. Én metode er at arbejde med kompetencekort. Hvis virksomheden er team-organiseret udfyldes kortene i forhold til de enkelte teams/produktionsgrupper, og ikke på grundlag af den enkelte medarbejders arbejdsopgaver. Det betyder at der kan lægges vægt på at udvikle helhedskompetence i arbejdsfællesskabet, frem for at fokusere på kompetenceudvikling af det enkelte individ. Processen forløber således: en faglig ekspert, f.eks. en mellemleder/ingeniør, udarbejder en skabelon for kompetenceprofilen for de enkelte teams. Medarbejderne får mulighed for at deltage i udarbejdelsen af profilen for eget team idet de kan udfylde skabelonen: føje mere eller mindre detaljerede kompetencekrav ind i skabelonen, krav de opfatter som vigtige for deres eget eller teamets funktion.

Materialet bearbejdes af ledelsen til kompetenceprofiler for hvert team. Disse profiler kan suppleres og revideres gennem diskussionsmøder der efterfølgende afholdes med de enkelte team.

Kompetencekortene beskriver begge sider i den klassiske gap-analyse: et teams forskellige kompetencer er listet op. For hver kompetence er der to niveauer: niveauet for hver enkelt medarbejder i dag, og mål-niveauet: det niveau man skal udvikle sig til for at kunne imødekomme fremtidens krav. Skaleringen i kompetencerne går fra: 0: jeg kan ingen ting. Til: 4: jeg er perfekt mht. den målte kompetence.

Udformningen af team-profilerne - skabelse af helhedsperspektiv gennem team overskridende diskussion.

Formålet med disse diskussionsmøder er fremme kontakt og udveksling mellem teamene, og at overskride grænserne mellem teamene, for at skabe et helhedsperspektiv på produktionsprocessen.

For hvert team gennemføres et møde med medarbejderne og produktionsledelsen. Det er muligt at finpudse de udarbejdede profiler hvad angår beskrivelsen af de eksisterende kompetencer på virksomheden. Herefter 
diskuteres og formuleres de mål der skal stilles op for fremtidens kompetencer. Målene skal både være realistiske og samtidig tage hensyn til fremtidige kompetencebehov.

Ledelsen har til opgave i kompetenceprofilerne at definere detaljerede mål for det fremtidige kompetenceniveauer.

Deltagerne har til opgave at beskrive situationer, hvor det er de ansatte der bedst kender til praksis og de kompetencer der kræves her. De skal skabe et helhedsperspektiv ved at fremhæve arbejdsprocesser hvor én persons arbejde har vigtige konsekvenser for andre medarbejderes arbejde. Gennem helhedsperspektivet fremhæves sammenhæng og indbyrdes afhængighed i arbejdsprocessen. Dette er et afgørende trin i kompetenceafklarings fremgangsmåden. Produktionsprocessen udgøre en helhed, hvor tidlige arbejdsprocesser påvirker efterfølgende arbejdsforløb.

Endelige udformning af kompetenceprofilerne

Gap analysen, der er indbygget i kompetenceprofilerne, indeholder en beskrivelse af mål for kompetenceudviklingen set i relation til de eksisterende kompetencer hos medarbejderne.

Produktionschefen formulerer mål i relation til de enkelte teams kompetenceprofiler. Målene formuleres (1) i forhold til kompetenceniveau, f.eks. på en skala fra ,jeg behersker opgaven helt“ til ,jeg behersker slet ikke opgaven“, og (2) i forhold til hvor mange medarbejdere i et team der skal beherske en bestemt opgave på et bestemt niveau. Et team kan f.eks. hensigtsmæssigt være sammensat af et par eksperter, nogle medarbejdere på mellemniveau, og nogle få uden særlige forudsætninger.

Kompetenceprofilerne udtrykkes således i kompetencekort, der indeholder:

- Kompetenceområderne for et team

- Teamets ambitionsniveau (mål) for hvert af de formulerede kompetenceområder

- Niveau for den eksisterende (faktiske) kompetence, på hvert af de formulerede kompetenceområder

- Hvor mange medarbejdere i teamet, der skal have kompetencer på de respektive niveauer

- Angivelser af afstande mellem kompetenceniveau nu og ønskede kompetenceniveau

Sammenkædning af personlige profiler og team-profiler

Når målprofilerne for teamene er udarbejdet, får de enkelte medarbejdere til opgave at beskrive egen personlige kompetence, ud fra disse målprofiler som skabelon. Samtidig får de ansatte mulighed for at diskutere deres personlige udviklingsplaner med udviklingschefen. Hermed skabes en kobling mellem kompetenceudviklingsprojektet med de faste rutiner i virksomheden mht. medarbejderudvikling. I denne fase af projektet anvendes kompe- 
tencekortlægningen som basis for en samtale mellem chef og medarbejdere. Udviklingschefen kan gå ind i diskussioner om divergenser i lederens vurdering af medarbejderens selvvurdering, altså en vurdering om over- og undervurdering af egen kompetence i selvvurderingen. Hermed tilføjes en kvalitet i kompetencevurderingen i forhold til de realkompetencevurderinger der ofte ses, der alene bygger på selvvurdering.

Formulering af kompetencebehov/uddannelsesbehov (kompetensluckorna), og hvordan de kan imødekommes af resp. interne og eksterne resourcer.

Med reference til kompetencekortene, og ovenstående sammenholdelse af personlige og team-profiler, udarbejder ledelse og konsulent kompetenceudviklingsbehovet, for hvert team, dvs. de kompetencer der mangler og som skal udvikles.

I forhold til efter- og videreuddannelse, og virksomheders omkostninger i forbindelse hermed, er det afgørende, at virksomhedens uddannelsesbehov ofte i et vist omfang kan dækkes af ekspertise som virksomheden selv har, og at det kun er en del af uddannelsesbehovet der behøver blive dækket af efter- og videreuddannelse der er ekstern i forhold til virksomheden.

Justering af kompetenceprofilerne og inddragelse i uddannelsesplaner Teamene får lejlighed til at reagere på resultatet af kompetence kortlægningen:

- Viser kompetencekortene det faktiske/eksisterende kompetenceniveau, og

- Hvordan ønsker medarbejderne at uddannelserne skal gennemføres?

- I denne fase kan medarbejderne typisk diskutere:

- Eget kompetenceniveau og kompetencemål

- Egen kompetencevurdering sammenholdt med kollegers vurdering af medarbejderens

- Sselvvurdering (over- eller undervurdering?)

- Hvordan man bedst kunne afhjælpe mangel på kompetencer (kompetencebehov)

Den deltagelses skabende metode er forbundet med en række fordele:

- $\quad$ en ofte fremført kritik kompetencekortlægninger (særlig ved selvvurderinger) er, at de kvantitative udtryk for mål ikke er sammenlignelige, fordi medarbejderne har givet dem efter skøn (,på känn“). Ved denne metode fremkommer en intern skala for kompetenceniveauer, hvor tallene blot er symboler, hvis mening bliver forhandlet og skabt fortolkning af, i teammøder. Kompetencekortet er et resultat 
af forhandling på arbejdspladsen, og kan ikke uden videre overføres til andre arbejdspladser.

- Proceduren bidrager til at „kompetence“ ikke behøver blive forstået som en personlig egenskab, og en bedømmelse af om en ansat er god eller dårlig. Det gør det lettere at opfatte kompetence som en størrelse der kan udvikles, og i denne udvikling kan hele teamet deltage. Kompetencekortet er en medarbejders arbejdsredskab, ikke medarbejderens personlighed.

- Ovenstående støttes af at graferne i kompetencekortlægningen viser hvordan en persons kompetenceniveau varierer på forskellige delområder af en arbejdsopgave. Der er ikke billeder af medarbejdere som generelt gode eller dårlige i deres arbejde.

- I nogen team får man øjnene op for at uddannelsesbehovene kan imødekommes ved den ekspertise, der allerede findes i teamet.

De ansatte arbejder med formulering af egne uddannelsesplaner således at hvert team fremlægger deres egen prioriteringsliste over uddannelse, som teamet ønsker under en eller anden form i fremtiden. På dette grundlag formulerede ledelsen retningslinier for nogle år frem. Uddannelsesplanen fører til udarbejdelsen af et uddannelsesbudget. I de efterfølgende år gennemføres uddannelse i virksomheden i overensstemmelse med denne plan.

Strategibærende faktorer.

Deltagelse - medarbejderinvolvering - er et fremtrcedende element. Deltagelsen i projektet starter tidligt, i planlægningsfasen og inkluderer således både: udformningen af kompetenceprofilerne og vurdering af kompetenceprofilerne

Ledelsens betydning. Projektets kobling til virksomhedens rutiner på personaleområdet, f.eks. personaleudviklingssamtaler.

Skabelsen af en nær sammenhæng mellem uddannelsesbehov og den effektuerede uddannelse

\section{Effekter}

Sammenfattende fremtræder følgende felter som de tydeligste effekter af projektet:

- Medarbejderne tager i højere grad ansvar for udviklingen af de nødvendige kompetencer i teamet, og for deltagelse i uddannelse. Holdningerne til uddannelse bliver mere positive.

- Et mere åbent samtaleklima

- Udvikling af en korpsånd (teamanda)

- $\quad$ Endret holdning til læring og undervisning af andre. Tidligere blev dette betragtet som en separat foreteelse, men der var en tendens til at 
se det som en del af arbejdet. Refleksion over behov for uddannelse, blev ligeledes set som en del af arbejdet. Man kan sige at medarbejdernes opfattelse af, hvad et arbejde er, blev ændret og udvidet, således at det indbefattede læring og kompetenceudvikling og som en integreret del.

Vigtig i de konstaterede effekter er, at effekterne overskrider et individniveau, og f.eks. viser sig på gruppe-niveau, i det der her kaldes arbejdsfællesskabet. Arbejdsfællesskabet søger at lære sig - ud over udviklingen af den individuelle erhvervskompetence - nye måder at fungere på for at vedligeholde kompetencen. Man har lært sig at diskutere kompetencen som en del af arbejdet, og ikke som en personlig egenskab.

Der var ikke blot tale om intra-gruppe effekter. I projektet arbejdede man med det enkelte teams betydning for produktionen som helhed, og for at udvikle et samspil mellem de enkelte team, altså inter-gruppe ændringer. Det blev vurderet af ledelsen, at der skete en forbedring a dialogen, såvel inden for de enkelte teams, som mellem ledelsen og medarbejderne.

Som det vigtigste resultat fremstår: medarbejderne har lært en diskuterende arbejdsmåde (arbetssätt)

\section{Model 4: E-læring ${ }^{19}$ og fleksibel læring på arbejdsplad- sen. Etablering af mini-læringscentre på arbejdspladsen.}

Grundlaget for denne model er ønsket om at skabe en vedvarende organisation der sikrer løbende kompetenceudvikling af medarbejderne på arbejdspladsen. Og her er begrebet „kompetence“ ikke et tilfældigt valgt ord, men centralt for hele tænkningen. Kompetence defineres som et individs kapacitet til at handle kyndig, effektivt, bevidst, strategisk og reflekteret $i$ en foreliggende situation, hvilket indebcrer en integration af praktisk og teoretisk kundskab.

Kompetence skabes gennem et møde og integration imellem:

- Formel og uformel læring, der indebærer teoretisk og praktisk kundskab

- Individuel og organisatorisk læring

Den grundlæggende tænkning er vist i nedenstående model:

\footnotetext{
${ }^{19}$ Begrebet E-læring dækker over læring med og gennem informations- og kommunikationsteknologi (IKT). I bred betydning korresponderer det med det internationale begreb CSCL: Computer Supported Collaborative Learning.
} 


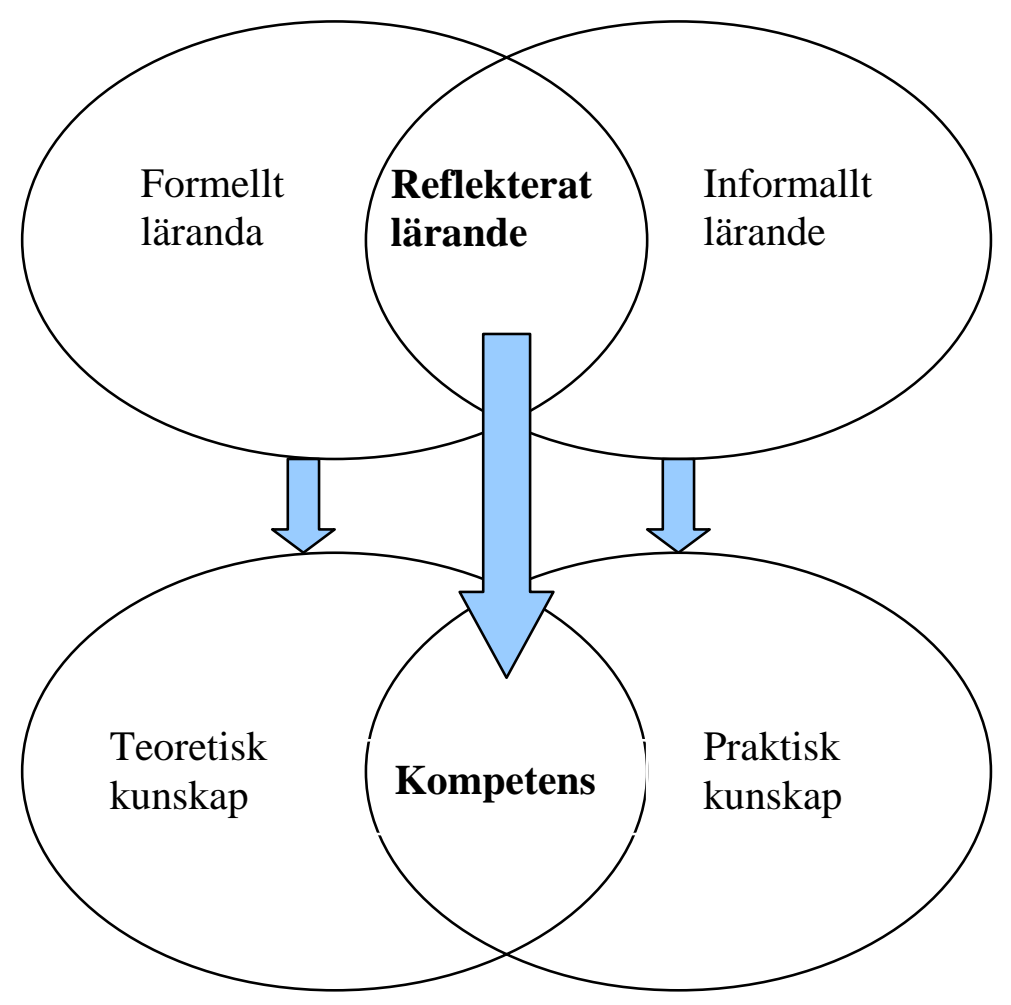

Figur 1: Reflekterat lärande leder till kompetens.

I en redegørelse for modellen peger forfatterne på forskning der viser, at formel uddannelse ofte forbedrer mulighederne for at individet kan drage nytte af den informelle læring på arbejdspladsen. Og omvendt viser forskning at en person med stor praktisk erhvervs viden har god baggrund for at deltage i formel uddannelse der relaterer sig til arbejdspladsens forudsætninger.

Mini-læringscentre på arbejdspladsen er det organisatoriske og praktiske arrangement hvorigennem udvikling af kompetence - i denne forståelse - får de optimale betingelser. Minilæringscentre kan betragtes som pæedagogisk støttesystem der er relateret til arbejdspladsen og som er en vigtig forudsætning for at kombinere både formel og uformel læring, og individuel og organisatorisk læring. Visionen er, at læring gennem minicentrene skal indgå som en naturlig del af virksomhedens udviklingsstrategi.

Et minilæringscenter kan placeres på den enkelte arbejdsplads i et lokale, der er indrettet hertil. Lokalet skal indeholde en række læringsfaciliteter: teknisk udrustning til netbaseret kommunikation (computere tilkoblet internettet) og hvor interaktivt studiemateriale er tilgængeligt. Dette støttesystem til arbejdspladsens læring skal have støtte fra et eksternt støttesystem, i form af et læringscenter/voksenuddannelsescenter, der kan fungere som organisator. I planlægningen og udformningen af minilæringscentret inddrages arbejdspladsens ledelse og fagkyndige. 
Der er tale om en efterspørgselsstyret uddannelse, hvor indhold, form og realisering varierer og bestemmes i dialog med deltagerne.

Minilæringscentret giver mulighed for at arbejdspladsens medarbejdere tilmelder sig kurser, hvor de kan studere i den takt der passer for dem, og på tidspunkter der både passer dem selv og arbejdspladsen. Uddannelsen bygger på selvstændig aktivitet, eget ansvar og samarbejde i studiegrupper, med støtte af E-læring. E-læring indebærer nogle nye muligheder: at kunne arbejde selvstændigt og i sit eget tempo, at kunne kommunikere med andre personer over store afstande, hvor geografisk afstand ikke spiller nogen rolle, mulighed for hurtigt at få hjælp og støtte af lærere, mv. Kontakten med lærerne (på uddannelsesinstitutionen) er løbende og formidles via computere med netadgang.

Denne form for læringsarena er integreret i virksomhedens personaleudvikling, f.eks. ved at knytte an til MUS, medarbejderudviklingssamtaler. Endvidere er etablering af studievejledere et vigtigt værktøj til at fremme et læringsforløb der er tilpasset den enkelte medarbejders forudsætninger og behov.

Denne form for arbejdspladslæring har fordele i sammenligning med traditionel formel uddannelse.

Læring der på denne måde er koblet til arbejdspladsen øger muligheden for at koble teori til den erfaringsbetingede læring. Hermed bliver den direkte nytte af det lærte tydelig, hvilket er en væsentlig motiverende faktor for at medarbejdere engagerer sig i uddannelse. Denne form for arbejdspladslæring kan også fungere som støtte til medarbejdere der er uddannelsesfremmede eller kortuddannede: når uddannelse er knyttet til arbejdspladsen bliver læring noget hverdagsagtigt og mere selvfølgeligt. Arbejdspladsen som det sted hvor læring finder sted kan i sig selv give tryghed, og arbejdet med læring kan foregå blandt grupper af arbejdskolleger, hvor man kollegialt kan hjælpe og støtte hinanden. Disse forhold er specielt vigtige for kortuddannede med negative erfaringer fra skoletiden.

I denne model bliver arbejdspladsen som arena for uddannelse og læring koblet til en udvikling af virksomheden og organisationen. Arbejdspladsen bliver et læringsmiljø. En del af arbejdstiden bliver til læringstid. Læring kan baseres på arbejdserfaringer og koblingen mellem teori og praksis kan ske på en ligefrem måde. Medarbejderne kan direkte anvende de kundskaber de har erhvervet i arbejdet i kurset, og uddannelsen opleves derfor som meningsfuld.

Arbejdspladslæring i denne form indebærer også fordele for virksomhedens ledelse idet uddannelsesforløbene kan formes efter de kompetencebehov som virksomheden oplever.

Læring i ovennævnte form indeholder en række forhold der kræver nytænkning og fleksibilitet hos både arbejdspladsledere og uddannelseskoordinatorer og -ansvarlige. Blandt disse forhold kan nævnes: lærerrollen, de deltagendes motivation, ansvar for egen læring og virksomhedsle- 
delsens engagement i udformningen af uddannelsens indhold og gennemførelse.

Der kan særlig fremhæves tre redskaber, der er af afgørende betydning for at få denne form for arbejdspladslæring til at fungere succesfuldt: studievejledning, individuelle handlingsplaner og vejlederrollen.

Studievejledningen giver medarbejderne en vigtig støtte i deres læringsforløb, og kan i et vist omfang kompensere for fraværet af den traditionelle lærer i undervisningsforløbene. Studievejledningen kan give overblik og en tydelig struktur for kurserne og kan indeholde oplæg til opgaver under kurset, der kan danne grundlag for dialog mellem deltagerne og læreren og evt. mellem deltagerne på forskellige arbejdspladser.

Den individuelle handlingsplan formuleres på baggrund af en indledende dialog med den studerende, hvor der sker en klargørelse af mål for uddannelsen, kursusindhold og krav om forudsætninger. I handlingsplanen formulerer medarbejderen selv sine mål med uddannelsen. En støtte til udbyttet af kurset kan også være deltagelse i et forberedelseskursus, der give forståelse for fleksibel læring og nødvendige forudsætninger for E-learning og netbaseret kommunikation, der indgår i kurserne.

Vejlederens rolle i denne form for arbejdspladslæring er væsentlig. Læring i denne sammenhæng er ikke en isoleret individuel aktivitet. Læring er en proces der kræver støtte personlig støtte, praktisk hjælp og ekstern ekspertkompetence. Deltagerne skal have mulighed for personlige kontakter med vejledere. Kontakt med vejledere kan formaliseres efter et skema, eller foregå efter behov. I vejlederens rolle indgår at fungere som mentor, forbillede og personlig støtte. I funktionen indgår endvidere at være instruktør, udgøre en pædagogisk støtte samt foretage en dokumentation af deltagernes læring, f.eks. gennem en logbog. Det kræver en særlig uddannelse at kunne udfylde denne rolle som vejleder.

Strategibærende faktorer.

Følgende faktorer fremhæves som væsentlige succesfuld arbejdsplads læring:

- Muligheden for at tage udgangspunkt i erfaringsbaseret læring, herunder muligheder for at studere i arbejdstiden og i et miljø som medarbejderne føler sig hjemme i.

- Tilpasning af uddannelsen til den enkelte. Deltagerne kan læse og arbejde i deres eget tempo, og ikke er styret af en lærer. Uddannelsen opleves ikke som „,skoleagtig“, men bygger på selvstændig aktivitet, eget ansvar og samarbejde i studiegrupper.

- Tilgængelighed til hensigtsmæssig teknisk udrustning (undervisningsteknologi og læringsressourcer) på arbejdspladsen. E-læring indebærer her nogle nye muligheder: at arbejde selvstændig og i eget tempo, at kommunikere med deltagere over store afstande, hurtigt at få hjælp fra lærere mv. 
- Udvikling af interaktivt studiemateriel som støtte for studier under fleksible former

- Anvendelse af vejledere på arbejdspladsen. Vejlederne skal sammenkoble den lærende med uddannelsessystemets forskellige dele, og ved at støtte og skabe forudsætninger for deltagernes læring

- Adgang til lærere. Læreren har gennem deres placering i et uddannelsescenter og ved hjælp af netadgang (distansteknik) en løbende kontakt med kursusdeltagerne.

- Uddannelsen tilpasses produktionen, hvilket bevirker, at uddannelsen økonomisk er effektiv og imødekommer virksomhedens kompetencebehov.

- Forankring i virksomhedsledelsen. Det er vigtigt at den øverste ledelse i virksomheden prioriterer og støtter uddannelsen i et langsigtet perspektiv og ikke begrænser sig til at se uddannelse som en måde hvorpå man på kort sigt kan rekruttere kvalificeret personale.

- Individuel og organisatorisk læring skal forstærke hinanden. Vi ved at det ikke er tilstrækkeligt at sende enkeltpersoner på kursus for at forbedre en arbejdsplads. Det et individ lærer på kursus er sjældent direkte anvendeligt på en arbejdsplads, så uddannelse fører ofte til udvikling af individer, men ikke udvikling af arbejdspladser. Det er vigtigt at arbejdspladsen sikrer forudsætninger for at det lærte kan anvendes, bl.a. i form af støtte til medarbejderen og etablering af et dispositions rum for medarbejderen i arbejdet.

De vigtigste faktorer kan sammenfattende siges at være

- Tilgængelighed

- Fleksibilitet

Væsentlig er at minicentrene indgår som en naturlig del af virksomhedens udviklingsstrategi.

At læringsaktiviteterne i mini-læringscentrene er forbundet med væsentlige personaleudviklingsaktiviteter i virksomheden, f.eks. medarbejderudviklingssamtaler.

Effekter af læringen skal også kobles til arbejdspladsens situation f.eks. således at øget kompetence fører til arbejdsopgaver med større krav og udfordringer, eller større muligheder for indflydelse.

Minilæringscentrene skal være støtte af eksterne formelle uddannelsesinstitutioner.

Ny lærerrolle til at støtte læreprocessen er væsentlig. Det fremhæves endvidere at studievejledning, personlige handlinsplaner og vejlederens funktion er væsentlig. 
Resultater og effekter.

Læringsaktiviteterne skaber mulighed for at kombinere praktik og teori og skaber hermed høj motivation for læring.

Der udvikles også en fleksibilitet hos deltagerne i forhold til læring bundet af tid og rum.

Væsentlig er en øget interesse for uddannelse og læring og initiativer til at lære af hinanden.

\section{Model 5: Arbejdspladsen som ramme og læringsmiljø for medarbejdernes kompetenceudvikling. Udvikling af et læringssystem på arbejdspladsen.}

I denne model finder kompetenceudvikling af medarbejderne ikke sted gennem efter- og videreuddannelse, ikke gennem kurser og ikke gennem den lineære to trinsmodel hvor kompetencer først erhverves og siden anvendes. Der er derimod tale om, hvad der er kaldt den interaktive strategi, hvor kompetence udvikles og anvendes parallelt. Arbejdspladsen er læringsmiljøet, hvor læring finder sted, ofte i en kombination af mange forskellige former for læreprocesser. Læring kan således finde sted i forskellige former for ikke-formel læring, som f.eks. sidemandsoplæring. Som uformel læring finder læring sted gennem den måde arbejdet er organiseret på, f.eks. et teamorganiseret arbejdsorganisering, gennem den måde arbejdsopgaverne er udformet på, gennem refleksionsprocesser og vidensdelingsprocesser. Refleksion og videndeling kan være institutionaliseret og integreret i produktionsprocesserne, som det kan forekomme i møder og særligt indrettede refleksionsrum indrettet i produktionen. Refleksion og videndeling kan også være organiseret i en særlig udviklingsafdeling, der er en parallel organisation til arbejdsorganiseringen.

Inden for denne model kan vi således se to variationer:

5a. Læringsmulighederne er integreret i arbejdspladsens organisation.

Inden for denne model kan vi generelt sige at følgende karakteriserer et godt læringsmiljø i arbejdet:

- Arbejdsopgaverne. Arbejdsopgaverne er indrettet så de støtter læring ved:

- $\quad$ at der findes variation i arbejdet hvad angår: hvad man gør, hvordan, med hvem, hvor og hvornår

- $\quad$ at arbejdsopgaverne har et udfordrende indhold i forhold til medarbejderens forudsætninger

- at medarbejderne får feed-back på udført arbejde

- $\quad$ at der findes autonomi (frihedsgrader) i tolkningen og udførelsen af arbejdet 
- $\quad$ at arbejdsopgaver delegeres

- $\quad$ at der er mulighed for medarbejderne til at udvikle et helhedsperspektiv

- $\quad$ at det er muligt af lære af fejl

- Støtte for læring i det daglige arbejde, f.eks. gennem:

- møder med erfaringsudveksling og refleksion

- vejledning, kollegial supervision, brug af mentor mv.

- udviklingsprojekter

- efterspørgselstyret uddannelsestiltag

- En arbejdsplads læringskultur er karakteriseret ved:

- $\quad$ åÅbenhed og tillid, snarere end angst og usikkerhed

- iInitiativ og risk-taking understøttes

- $\quad$ tTolerance over for forskelligheder, usikkerhed og fejl

- oOpmuntring til at tænke alternativt og afprøvning af indarbejdede tænkemåder og arbejdsmåder

Virksomheden er organiseret for både produktion og læering (udvikling), hvilket bl.a. kræver at tilstrækkelig tid og ressourcer afsættes til læringsog udviklingsaktiviteter

Ledelsens betydning, ledelseskompetence:

at ledelse på alle niveauer på arbejdspladsen forstår betydningen af og har kompetence til at organisere for og støtte lærings- og udviklingsprocesser

5b. Arbejdspladsen er organiseret som en parallel organisation: en arbejdsorganisation i samspil med en udviklingsorganisation. Udviklingsorganisationen er et lceringssystem på arbejdspladsen.

Eikeland\&Berg (1997) taler - med anvendelse af en metafor fra teaterlivet - om at befinde sig „på scenen“ og „bag senen“ De taler om arbejdsorganisering og udviklingsorganisering. Systematiseringen af arbejdet med udviklingsopgaver kaldes udviklingsorganisering og systematiseringen af arbejdet med driftopgaver kaldes arbejdsorganisering. I de to organiseringer kan medarbejderne befinde sig i forskellige relationer og roller i forhold til hinanden. De to organisationsformer har ikke hvert sit fysiske rum, der er snarere tale om to logikker at organisere sig efter. Arbejdsorganiseringen indebærer en rolleliste og en rollefordeling, og rollerne spilles „på scenen“ i arbejdsorganisationen. I udviklingsorganisationen sættes udviklingsaktiviteterne i system. Dette arbejde stiller andre krav til ledere og medarbejdere og kræver andre kompetencer. Billedligt foregår dette arbejde „bag scenen“. Ledere og medarbejdere træder ud af de roller de spiller i arbejdsorganiseringen og indtager de nye roller. Her undersøger man kritisk det der foregår „på scenen“ i arbejdsorganiseringen. Bag scenen reflekteres arbejdserfaringer og her bruges fejl og utilstrækkeligheder til at lære af. 
Ved læring forstås i denne sammenhæng en systematisk evaluering og forbedring af arbejdsformer, arbejdsdeling, organisering, arbejdsmiljø, ledelse mv. med henblik på målrealisering for både enkeltpersoner og fællesskab og på grundlag af sammenfatning og analyse af egne personlige og kollektive erfaringer fra arbejdet (organisations- og erhvervspraksis). (Eikeland 2006, p. 63).

Eikeland skelner mellem teoretisk læring og erfaringslæring. Begge former for læring inkluderer individuel læring og kollektiv læring.

Læringsformerne er anført i skemaet nedenfor (Ekeland\&Berg, 1997)

\begin{tabular}{lll}
\hline & Individuel læring & Kollektiv læring \\
\hline Teoretisk læring & $\begin{array}{l}\text { Individuelle kurser, læsning af bøger } \\
\text { mv. }\end{array}$ & Forelæsning/fælles lytning og læsning \\
Erfaringslæring & $\begin{array}{l}\text { Læring gennem handling: øvelser, } \\
\text { træning, tilvending }\end{array}$ & $\begin{array}{l}\text { Organisationslæring: fokusering på fælles } \\
\text { praksis. Hvordan arbejder vi i forhold til } \\
\text { hinanden og i forhold til opgaveløsning? }\end{array}$ \\
\hline
\end{tabular}

Den teoretiske læring - både den individuelle og den kollektive, - giver medarbejderen nye ord og begreber gennem hvilke verden tolkes og forstås. På denne måde åbner den teoretiske læring for nye indfaldsvinkler og perspektiver. Erfaringslæring drejer sig til forskel herfra i første række om at udvikle færdigheder.

Når læring finder sted i det etablerede læringssystem på arbejdspladsen sker det gennem en integration af de her fire nævnte læringsformer.

\section{Afslutning}

Ovenfor er beskrevet fem forskellige modeller for læring i arbejdet. Det skal anføres at forskellige kombinationer af de nævnte modeller ofte er de modeller der findes i praksis, og modellerne kan med fordel kombineres.

\section{Referencer}

Andersen, V., Clematide, B. og Høyrup,S.: Arbejdspladsen som læringsmiljø. Learning Lab Denmark, Roskilde Universitetsforlag, 2004. Især:

Steen Høyrup: Læringsformer, refleksionsprocesser og læringsrum i arbejdslivet, p. 73-98.

Eikeland, O. \& Berg. M.(1997) Medvirkningsbaseret organisasjonslæring og utviklingsarbeid i kommunene. Kommuneforlaget.

Steen Høyrup og Pernille Bottrup: Bæredygtighed på arbejdspladsen. Refleksion og læring i arbejdet. LO, april 2004
Steen Høyrup: Reflection as a core process in organisational learning. Journal of Workplace Learning, Vol. 16, No.8, 2004, p. 442-454

Høyrup, S. og Kjærgaard. C.: Nye læringsformer i arbejdslivet. 2. delrapport. Virksomhederne: Læring og udvikling i arbejdet. Erfaringer med det udviklende arbejde. Herunder: kap. 2: Cases. Kelsen A/S, p. 25-37.

Knud Illeris \& samarbejdspartnere: Læring i arbejdslivet. Learning Lab Denmark, Roskilde Universitets forlag, 2004 


\section{Päätelmät ja suositukset}

\section{Päätelmät:}

Mikä on tunnusomaista työpaikan menestyksekkäille oppimisstrategioille?

Päätelmät on jaettu kolmeen osaan:

1. Parhaiden käytäntöjen keskeiset tekijät

2. Konkreettisia malleja parhaista käytännöistä

3. Parhaiden käytäntöjen vaikutukset.

\section{Menestystekijät: parhaiden käytäntöjen keskeiset tekijät}

Päätelmistä voidaan yleisesti todeta, että havaitut menestystekijät ovat hyvin monimutkaisia. Suurin osa menestystekijöistä syntyykin eri tekijöiden välisistä suhteista, kuten virallisen ja epävirallisen oppimisen tai yksilöllisen oppimisen ja työpaikalla tapahtuvien muutosten vuorovaikutuksesta.

Alla olevassa menestystekijöiden yleiskatsauksessa on tiettyjä päällekkäisyyksiä. Tämä johtuu siitä, että tekijät eivät ole erillään toisistaan, vaan läheisessä vuorovaikutuksessa keskenään eri yhteyksissä. 


\section{Menestystekijät: yleiskatsaus}

1. Virallisen ja epävirallisen oppimisen yhdistyminen ${ }^{20}$

2. Työpaikan ja koulutuksen tarjoajan läheinen yhteistyö

3. Työpaikan johdon tuki ja oikeutus työpaikalla toteutettaville osaamisen kehittämistoimenpiteille

4. Henkilöstön osallistaminen

5. Jatko- ja täydennyskoulutuksen ominaispiirteinä

.5.1 opetuksen työpaikkalähtöisyys

5.2. tavoitteellisuus

5.3 joustavuus

5.4 kokemusperusteisen oppimisen käyttäminen lähtökohtana

5.5 teorian ja käytännön yhdistäminen kautta linjan

5.6 mahdollisuus oppimisresurssien hyödyntämiseen

5.7 vuoropuheluun perustuvat ja ongelmalähtöiset työskentelytavat, jotka antavat osallistujille mahdollisuuden aktiivisuuteen, toimintaan ja kokeiluihin sekä kurssitilanteen kytkemiseen oman työtilanteeseen

5.8 osallistujien varhaiset onnistumisen elämykset.

6. Reflektointimahdollisuudet ja niiden luominen

7. Yksilöllisen ja organisatorisen oppimisen yhdistäminen: yksilölliset kehitysprosessit ja työpaikan sosiaaliset muutosprosessit yhdistyvät

8. Jatko- ja täydennyskoulutus ja osaamisen kehittämistoimenpiteet osana työpaikan laajempaa kehitysstrategiaa

9. Työpaikan tuki muutoksille, jotka ovat seurausta osaamisen kehittämisestä, ja osaamisen kehittämisen yhdistäminen henkilöstön kehittämisrutiineihin

10. Henkilöstöllä kokonaiskuva työpaikan toiminnasta

11. Ohjaajien ja mentorien käyttö työpaikalla

12. Oppimista tukevien erityisroolien luominen työpaikalla

13. Työpaikasta luotu ihanteellinen oppimisympäristö, mikä edellyttää

13.1 työtehtäviltä tiettyjä ominaispiirteitä

13.2 arkioppimisen tukemista

13.3 oppimiskulttuuria

13.4 työpaikan toiminnan sellaista organisointia, että se tukee sekä tuotantoa että oppimista (kehitystä)

13.5 johdon panosta ja osaamista.

\section{Virallisen ja epävirallisen oppimisen yhdistyminen ${ }^{21}$}

Virallinen oppiminen on oppilaitoksissa tapahtuvaa institutionalisoitua oppimista. Epävirallisella oppimisella taas tarkoitetaan tässä yhteydessä päivittäisen työn yhteydessä tapahtuvaa arkioppimista. Oppimisympäristönä on tällöin työpaikka, oppimisella ei tarvitse olla erikseen määriteltyä tavoitetta, eikä oppija välttämättä tiedosta oppivansa työskentelyprosessin

\footnotetext{
${ }^{20}$ Käsite ”epävirallinen oppiminen” vastaa tässä englanninkielistä käsitettä ”informal learning”.
} 
yhteydessä. Työn organisointi, sisältö ja hoitaminen määrittävät paitsi sen, mitä kukin tekee ja milloin, myös sen, mitä työntekijät oppivat.

Professori Henrik Holt Larsen kirjoittaa tähän liittyen seuraavasti:

Arkioppiminen (epävirallinen oppiminen, toim.) on ensinnäkin usein parempi, tehokkaampi, joustavampi ja halvempi vaihtoehto uusien asioiden opettelemiseen kuin se, että ihmiset istutetaan koulunpenkkiin (virallinen oppiminen, toim.). Toiseksi lukuisat tutkimukset osoittavat, että parhaat oppimistulokset saadaan juuri arkioppimisesta -- (Henrik Holt Larsen, 2002, s. 12).

Tämän raportin keskeinen päätelmä eroaa kuitenkin hieman äskeisestä:

Työyhteisössä tapahtuva oppiminen on tehokkainta silloin, kun virallinen ja epävirallinen oppiminen eli kurssioppiminen ja arkioppiminen yhdistyvät.

Henrik Holt Larsen toteaa kuitenkin myös, että arkioppiminen ei tee tarpeettomaksi kursseilla tapahtuvaa osaamisen kehittämistä (Larsen, 2002, s. 12). Samaan näkemykseen yhdytään käsillä olevassa raportissa.

Käyttämällä tämän raportin terminologiaa asia voidaan muotoilla seuraavasti: Työpaikalla oppiminen on tehokkainta silloin, kun siinä yhdistyvät lineaarinen strategia - jossa osaamisen kehittäminen on kaksivaiheista, eli osaaminen ensin hankitaan ja sitten sitä käytetään - ja vuorovaikutteinen strategia, jossa osaamisen hankkiminen ja käyttö tapahtuvat rinta rinnan. Toisin sanoen päivittäisessä työssä tapahtuva epävirallinen oppiminen yhdistyy suunniteltuihin koulutustoimenpiteisiin.

Tähän parhaan käytännön monimutkaiseen menestystekijään sisältyy useita yksityiskohtaisempia tunnusmerkkejä, joiden avulla virallisen ja epävirallisen oppimisen välistä suhdetta ja yhdistymistä voidaan havainnollistaa:

- Työntekijät osallistetaan kurssien suunnitteluun käymällä vuoropuhelua, jossa selvitetään heidän koulutustarpeensa sekä näkemyksensä työpaikan kehitystarpeista ja ongelmista. Henkilöstön näkökulmaa, kokemuksia ja oppimistarpeita käytetään keskeisenä lähtökohtana kurssien suunnittelussa.

- Osaamisen kehittämisohjelmat perustuvat työpaikan omaan sisäiseen osaamiseen, joka on selvitetty esimerkiksi kehityskeskusteluissa tai validoimalla saavutettua osaamista. Aikuis- ja jatkokoulutustoimenpiteet on räätälöity työpaikalla yleisesti tunnustettuihin ja muotoiltuihin oppimis- ja kehitystarpeisiin.

- Koulutus tapahtuu työpaikalla tai siihen suoraan kytköksissä olevassa paikassa ja kokonaan tai osittain työajalla. Koulutuksen osallistujat koostuvat joko tiimeistä tai kaikista työpaikan tietyn yksikön työntekijöistä, esimerkiksi tuotantohenkilöstöstä, tai työpaikan kaikista työntekijöistä ja esimiehistä. 
- Koulutus on suunniteltu siten, että kurssijaksot ja harjoittelujaksot vuorottelevat. Kurssijaksojen tulisi olla varsin lyhyitä verrattuna harjoittelujaksoihin, jotka ovat yleensä pidempiä.

- Kurssijaksot perustuvat useisiin pedagogisiin periaatteisiin, joilla pyritään koostamaan ja yhdistämään teoreettista ja käytännön tietoa (työstä saatuja kokemuksia ja sisäistettyä mutta erikseen määrittelemätöntä tietoa, eli ns. hiljaista tietoa).

- Koulutukseen vähiten tottuneiden työntekijöiden tarkoituksenmukaisimmaksi koulutustavaksi on osoittautunut teorian jäsentäminen käytännön avulla. Käytännön tulisi toisin sanoen ohjata teorian ja teoriaopetuksen ajankohdan valintaa sekä teoriaopetuksen laajuutta. Teoriaa tulisi opettaa silloin, kun se on tarpeellista käytännön työn kannalta ja kun teoriatieto on välttämätöntä työtehtävien ja työhön liittyvien vaatimusten ratkaisemiseksi.

- Teoria ja käytäntö voidaan yhdistää työskentelemällä sekä deduktiivisesti (hyödyntämällä teorioita käytännön ongelmien ja työhön liittyvien ongelmien ymmärtämisessä ja analysoimisessa) sekä induktiivisesti (käytännön työstä saatuja kokemuksia ja esimerkkejä yleistetään ja tulkitaan mielekkään teorian pohjalta). Induktiivisista työskentelytavoista voidaan mainita esimerkkitapausten hyödyntäminen, harjoitukset sekä roolileikit. Yksi yleisistä induktiivisista periaatteista on osallistujien kokemusten ja näkökulmien käyttäminen lähtökohtana.

- Jos teoria perustuu yleisaineisiin, opetuksessa on mahdollista yhdistää yleistieto ja ammatillinen erityistieto.

- Osaamisen kehittämistä tukevien työskentelytapojen tulisi olla keskustelupainotteisia, ja niissä tulisi rohkaista osallistujia tarkastelemaan asenteitaan ja arvojaan aktiivisesti, tutkivasti, kokeilevasti, avoimesti ja vuorovaikutteisesti. Osallistujille tulisi myös antaa mahdollisuus toimintaan, joka voi olla joko kurssitilanteessa toteutettavaa „kuvitteellista“ toimintaa (esimerkiksi harjoitukset ja roolileikit) tai suunniteltua toimintaa, joka toteutetaan myöhemmin työtilanteessa.

- Harjoittelujaksoihin tulisi kuulua olennaisena osana pohdiskelu, jossa työntekijät tarkastelevat työhön liittyviä seikkoja ja ongelmia sekä muotoilevat ajatuksia tai tekevät aloitteita työhön tehtävistä parannuksista ja muutoksista. Nämä kurssiosiot tulisi yhdistää myöhemmin muuhun opetukseen pyrkimällä muokkaamaan, ymmärtämään, tarkastelemaan ja yleistämään niitä yhdessä. 


\section{Työpaikan ja koulutuksen tarjoajan läheinen yhteistyö}

Edellä esitelty parhaan käytännön menestystekijä on seurausta tekijän institutionaalisesta tasosta, eli virallisen ja epävirallisen oppimisen yhdistymisestä. Yhdistyminen taas edellyttää työpaikan johdon sekä aikuis- ja täydennyskoulutusta tarjoavien oppilaitosten läheistä yhteistyötä. Tähän monihaaraiseen yhteistyöhön sisältyvät seuraavat osat:

- Yhteistyö, jossa selvitetään työpaikan tilanne, ominaispiirteet, koulutustarpeet sekä ongelmat ja käytetään niitä lähtökohtana osaamisen kehittämistoimenpiteiden suunnittelussa ja toteutuksessa. Oppilaitos voi tässä alkuvaiheessa olla aloitteellinen työpaikkaa koskevien selvitysten toteuttamisessa.

- Yhteistyö, jossa selvitetään osaamisen kehittämisprojektin puitteet, menetelmät ja resurssit.

- Yhteistyö, jossa luodaan työpaikan ja kurssin välisiä läheisiä kytköksiä, vrt. edelliset kohdat. Tässä on erityisen tärkeää johdon oikeutus sille, että kurssilla suunnitellut parannukset sekä hankitut tiedot ja valmiudet voidaan siirtää työpaikalle. Lisäksi johdon on annettava hyväksyntänsä työpaikalla saatujen kokemusten ja ongelmien käsittelemiselle kurssilla.

- Yhteistyö, jossa seurataan suunnitelmien ja parannusten toteuttamista työpaikalla.

\section{Työpaikan ylimmän ja toimeenpanevan johdon tuki ja oikeutus työpaikalla toteutettaville osaamisen kehittämis- toimenpiteille}

Oppimisen edistäminen on johdon vastuutehtävä, kuten Henrik Holt Larsen toteaa (Larsen, 2002, s. 10). Saatavilla on kattavaa näyttöä siitä, että johdolla on keskeinen rooli työyhteisössä tapahtuvasta oppimisesta ja huomattava vastuu siitä. Johdolla on toisaalta keskeinen yleisrooli osaamisen kehittämisen oikeuttajana ja tukijana sekä sen edellyttämien resurssien ja puitteiden tarjoajana. Lisäksi johdon tulee tukea myös konkreettisia henkilöstön osaamisen kehittämistoimia työpaikalla. Tässä yhteydessä voidaan mainita, että johdon tulee avustaa kaikissa seikoissa, joita näissä päätelmissä pidetään keskeisinä työyhteisössä tapahtuvan oppimisen kannalta.

\section{Henkilöstön osallistaminen}

Henkilöstön osallistaminen (participation) on hyvin olennainen menestystekijä. Osallistaminen on työpaikan oppimiskulttuurin osa, koska se osoit- 
taa johdon pitävän työntekijöitä tuotannon ja kehityksen keskeisinä resursseina. Henkilöstön osallistaminen edistää olennaisesti myös motivaatiota osallistua tiedon jakamiseen ja osaamisen kehittämisjaksoihin.

Sekä henkilöstön kokemuksellisen tiedon (epävirallisella oppimisella saavutetun osaamisen) hyödyntäminen ja ilmaiseminen että eri näkökulmien yhdistäminen kokonaisnäkemykseksi edellyttävät huomattavaa henkilöstön osallistumista (Eikeland \& Berg, 1997). Edellä esitetystä ilmenee, että henkilöstön osallistamista sisältyy hyvin moniin yhteyksiin ja että se on siten keskeinen menestystekijä.

Henkilöstön osallistamista voi tapahtua monilla tasoilla ja monissa toiminnoissa, joista mainittakoon jatko- ja täydennyskoulutuksen suunnittelu ja toteutus, työpaikan suuret muutosprosessit, kokeilu- ja kehityshankkeet, tuotantoryhmän työsuunnittelu ja oppimisprosessien suunnittelu, esimerkiksi „oppipoikana“ oleminen (muu kuin virallinen oppiminen) sekä työpaikan kehitysorganisaatiossa mukana oleminen.

\section{Jatko- ja täydennyskoulutuksen ominaispiirteet}

Opetuksen työpaikkalähtöisyys. Opetusjaksot on räätälöity työpaikan tilanteen ja osaamisen kehittämistarpeiden mukaisiksi.

- Tavoitteellisuus. Koulutus on luotu selkeästi muotoiltujen ja työpaikan kehitykseen liittyvien tavoitteiden toteuttamiseksi.

- Joustavuus. Opetusta ja oppimista mukautetaan toteutusvaiheessa jatkuvasti henkilöstön ja työpaikan tarpeiden ja ongelmien mukaisesti. Yksilöllisemmin suunnitelluissa koulutusjaksoissa joustavuus merkitsee oppimisen mukauttamista esimerkiksi kunkin työntekijän edellytyksiin, oppimistahtiin, kokemuksiin ja oppimistyyliin.

- Kokemusperusteisen oppimisen asettaminen lähtökohdaksi. Koulutusjaksoihin sisältyy teoreettisen tiedon ja käytännön tiedon/ kokemusten välistä vuorovaikutusta, mutta työntekijöiden kokemukset ja työtilanne ovat silti keskeinen lähtökohta ja opetusta ohjaava tekijä.

- Teorian ja käytännön yhdistäminen kautta linjan. Teoriaa käytetään linssinä ja näkökulmana käytäntöön; käytännöstä tehdään yleispätevää ja sitä hahmotetaan teorian avulla.

- Mahdollisuus oppimisresurssien hyödyntämiseen. Oppimisresurssit voivat olla esimerkiksi opettajia, ohjaajia ja mentoreita - jotka voivat olla läsnä sekä koulutusjaksoilla että työpaikalla -, vuorovaikutteista oppimateriaalia sekä tieto- ja viestintätekniikkaan perustuvia ja verkkopohjaisia oppimisvälineitä.

- Vuoropuheluun perustuvat ja ongelmalähtöiset työskentelytavat. Tällaiset työskentelytavat antavat osallistujille mahdollisuuden 
aktiivisuuteen, toimintaan, kokeiluihin ja teorian ja käytännön yhdistämiseen sekä kurssien kytkemiseen oman työtilanteeseen.

- Osallistujien varhaiset onnistumisen elämykset. Koulutusjaksoilla pyritään luomaan osallistujille varhaisia onnistumisen elämyksiä. Tällöin osallistujat sitoutuvat oppimisprosesseihin, pitävät opittua hyödyllisenä ja käyttökelpoisena työtilanteensa kannalta sekä kokevat oppimisen mielekkääksi ja sellaiseksi, että opittu voidaan siirtää työpaikalle ja että se voi lisätä vaikutusmahdollisuuksia.

\section{Reflektointimahdollisuudet ja niiden luominen}

Reklektio on monimutkainen prosessi, jossa yhdistyvät ajattelu, toiminta ja kokemukset. Reflektoida voi joko yksin tai yhdessä muiden kanssa, ja reflektoinnin kohteina voivat olla joko oma toiminta ja omat kokemukset tai yhteinen toiminta ja yhteiset kokemukset. Reflektio voidaan määritellä

\footnotetext{
älylliseksi ja mahdollisesti myös sosiaaliseksi toiminnaksi, jossa yksilö tutkiskelee omaa toimintaansa tietyissä sosiaalisissa tilanteissa sekä tarkastelee ja arvioi uudelleen aiempia kokemuksiaan. Hän analysoi sosiaalisen toimintansa ja sosiaalisten tapahtumien sekä tapahtumaketjujen syy-seuraus-suhteita ja voi tehdä päätelmiä tulevasta toiminnasta sekä suunnitella sitä.
}

Reflektio edellyttää "miettimistaukoa” ja sitä, että ihminen ottaa askelen taaksepäin ja tutkiskelee oman toimintansa ja sosiaalisten prosessien välisiä yhteyksiä sekä tarkastelee omia ja yhteisiä kokemuksia. Reflektioon sisältyy menneisyyden ja tulevaisuuden tarkastelua ja tulevaisuuteen suuntautuvaa toimintaa, jolla pyritään ratkaisemaan ongelmia ja saamaan uusia näkemyksiä ja käsityksiä työpaikan olosuhteista.

Monissa oppimisteorioissa korostetaan reflektion olevan oppimisprosessien, ja siten myös arkioppimisen ja kurssioppimisen, olennainen osa.

Kollektiivisen reflektion (sosiaalisissa prosesseissa tapahtuvan reflektoinnin) tärkeitä osatekijöitä ovat

- virheistä oppiminen

- tiedon jakaminen

- tavoitteisiin ja visioihin liittyvä yhteenkuuluvuus (vision sharing)

- tavanomaisen ja rutiininomaisen ajattelun haastaminen (challenging groupthink)

- palauteprosessit, eli palautteen pyytäminen sekä aloitteiden ja kehitysprojektien seuranta

- (Høyrup, 2004).

Onnistuneen työyhteisössä tapahtuvan oppimisen tunnusmerkkinä on hyvien reflektointimahdollisuuksien järjestäminen. 
Opintojaksot voivat tarjota puitteet reflektiolle, ja ne voivat tukea reflektiota sekä useita sen osatekijöitä, kuten kokemusten arviointia ja vertailua sekä kokemusten uudenlaista tarkastelua ja kriittistä arviointia mm. uusien teoreettisten näkökulmien pohjalta. Tulevaisuuteen suuntautuvaa ajattelua ja toimintaa voidaan harjoitella kokeellisesti opetustilanteissa, tai niitä voidaan edistää työpaikan arjessa. Reflektointiprosesseissa voivat siten yhdistyä teoria ja käytäntö, virallinen ja epävirallinen oppiminen sekä yksilölliset prosessit ja työpaikan sosiaaliset prosessit. Tällainen reflektoiva oppiminen on olennaisen tärkeää osaamisen kehittymisen kannalta.

Työpaikoilla reflektiota voi esiintyä erilaisissa yhteyksissä, kuten erityyppisissä kokouksissa ja palavereissa, eli suunnitelluissa ja institutionalisoiduissa kokouksissa sekä spontaaneissa palavereissa. Työpaikalle voidaan perustaa pieniä reflektointihuoneita tuotantotilojen yhteyteen, jolloin pohdiskelu ja työskentely ovat suunnitelmallisia ja toisiinsa kytkeytyviä toimintoja. Reflektiota sisältyy yleensä työpaikan kokeilu- ja kehitystyön suunnitteluun, ja reflektion keskeisenä osatekijänä voidaan pitää kehitystoimenpiteiden seurantaa, joka on keskeinen työpaikan kehitys- ja oppimisprosessien ylläpitäjä.

Reflektio voi olla myös oppivan organisaation työskentelyn kiinteä osa.

\section{Yksilöllisen ja organisatorisen oppimisen yhdistäminen: työpaikan yksilölliset kehitysprosessit ja sosiaaliset muutosprosessit yhdistyvät}

Osaaminen ei ole pelkkää tietoa, vaan se on yhteisnimitys esimerkiksi tiedoille, taidoille, valmiuksille ja asenteille, joita voidaan hyödyntää työhön liittyvien vaatimusten ja haasteiden ratkaisemisessa. Osaaminen muutetaan teoiksi työpaikan muodostamalla sosiaalisella kentällä. Tälle parhaalle käytännölle on luonteenomaista se, että työpaikan arjessa tuetaan osaamisen hyödyntämistä ja annetaan sille tilaa. Seuraavassa on muutamia konkreettisia esimerkkejä:

- Kun työntekijät palaavat työhönsä osaamisen kehittämisjakson jälkeen, he eivät valahda takaisin samoihin vanhoihin työtilanteisiin ja -rutiineihin. Sen sijaan aloitetaan siirtymäkausi, jonka aikana työntekijät voivat kokeilla ja käyttää uutta osaamistaan.

- Osaamisen kehittäminen johtaa työntekijöiden työtilanteen muuttumiseen esimerkiksi siten, että työtehtävistä tulee vaativampia, monimutkaisempia ja vastuullisempia tai että ne edellyttävät entistä vapaampia toimintamahdollisuuksia (enemmän määräämisvaltaa). Omaan työhön liittyvät vaikutusmahdollisuudet kasvavat. Osaamisen kehittäminen yhdistyy urakehitykseen, ja se voi johtaa myös 
palkankorotuksiin tai yleisemmin palkkausjärjestelmään, joka kannustaa kehittämään osaamista.

- Jatko- ja täydennyskoulutusjaksoihin sisältyy päivittäisen työn parantamista koskevien suunnitelmien laatiminen sekä niiden toteuttaminen työpaikalla.

- Työpaikan kehitystä seurataan ja kehitykselle asetetaan selkeät tavoitteet. Lisäksi seurataan koulutusjaksolla laadittujen parannussuunnitelmien tai kokeilu- ja kehitysprojektien toteutumista. Seurannalla on keskeinen rooli organisatorisessa oppimisessa, ja seuranta tarkoittaa sitä, että työntekijät ja johto tarkastelevat yhdessä erilaisten kehitystoimenpiteiden toteutuksen seurauksia työpaikalla. Seurausten määrittelemiseksi ja arvioimiseksi on välttämätöntä, että työpaikalla on selkeät kehitystavoitteet. Näin voidaan kartoittaa halutun ja todellisen kehityksen väliset mahdolliset erot. Tämä taas voi pohjustaa uusia toimenpiteitä tai kehityshankkeita, jotka voidaan nähdä osana organisatorista oppimista.

\section{Jatko- ja täydennyskoulutus sekä osaamisen kehittämis- toimenpiteet osana työpaikan laajempaa kehitysstrategiaa}

Osaamisen kehittämistoimenpiteitä ei pidä suunnitella irrallisiksi, tarkkaan rajatuiksi ja itsenäisiksi projekteiksi, jotka ovat erillään työpaikan toiminnan kokonaisuudesta. Työpaikan parhaille oppimiskäytännöille on tunnusomaista se, että ne ovat työpaikan yleisen kehitysstrategian ja tavoitetyön elimellinen osa ja kytköksissä muihin oppimis- ja kehitysprojekteihin.

\section{Työpaikan tuki muutoksille, jotka ovat seurausta osaamisen kehittämisestä, ja osaamisen kehittämisen yhdistäminen henkilöstön kehittämisrutiineihin}

Yksi keskeisistä rutiineista on tässä yhteydessä kehityskeskustelu. Keskusteluissa voidaan kartoittaa henkilöstön koulutustarpeet ja käyttää niitä työyhteisössä tapahtuvan oppimisen lähtökohtana. Vastaavasti kehityskeskusteluja voidaan käyttää lähtökohtana pyrittäessä suhteuttamaan saavutettu osaaminen esimerkiksi urakehitykseen, uusiin työtehtäviin ja palkankorotuksiin. Työpaikalla voidaan validoida saavutettua osaamista antamalla kirjallisia todistuksia, kuten tiettyjen koneiden käyttöön ja työtehtävien hoitoon liittyviä "ajokortteja”. 


\section{Henkilöstöllä kokonaiskuva työpaikan toiminnasta}

Työpaikan tehokkaat oppimisstrategiat auttavat työntekijöitä saamaan kokonaiskuvan työpaikan toiminnasta. Kokonaiskuvaa voidaan luoda monella tavalla, kuten koulutukseen osallistujien valinnalla ja ryhmittelyllä (muodostamalla eri osastojen välisiä ryhmiä, jolloin syntyy rajat ylittävää kokemustenvaihtoa).

Lisäksi kokonaiskuvaa voidaan luoda töiden organisoinnilla, mikä vaikuttaa olennaisesti oppimisympäristöön. Esimerkiksi tuotantoryhmien vastuualueet voidaan rajata siten, että ryhmällä on vastuuta paitsi itsestään myös kokonaisuudesta, kuten yhteistyöstä suunnittelu- ja laadunvarmistusosastojen kanssa. Kokonaiskuvan saamista edistää myös työntekijöiden osallistaminen työpaikan kokeilu- ja kehitysprojekteihin sekä vastaavaan toimintaan. Yhtenä keinona on myös kokouksissa ja opetuksessa tapahtuva reflektointi sekä reflektion hyödyntäminen työn organisoinnin olennaisena osana. Kokonaisuus syntyy juuri reflektion avulla. Eikeland \& Berg huomauttavat, että kenelläkään - sen paremmin johdolla kuin työntekijöilläkään - ei ole mahdollisuutta ottaa kokonaisuutta suoraan haltuunsa (Eikeland \& Berg, 1997).

Samalla kokonaisnäkemys on olennaisen tärkeä: työntekijöillä on usein tietoa siitä, miksi jotkin asiat eivät toimi, sekä hyviä ideoita ongelmien ratkaisemiseksi. Viestinnän ja yhteistyön tärkeyttä organisaatiolle selittääkin osittain se, että kunkin työntekijän ja esimiehen oma näkökulma on rajallinen, jolloin tarvitaan kokonaiskuvaa. Kokonaiskuvan luominen edellyttää keskustelua ja toisten ihmisten näkökulmien ymmärtämistä sekä pyrkimystä eri näkökulmien yhdistämiseen (Eikeland \& Berg, 1997). Tämä voi tapahtua mm. reflektion avulla.

\section{Ohjaajien ja mentorien käyttö työpaikalla}

Tämä on myös yksi tapa, jolla työpaikka voi tukea työntekijöiden osaamisen kehittämistä. Ohjaajien ja mentorien tehtäviä ja rooleja voidaan kuvailla monin tavoin. Tässä voidaan lyhyesti mainita, että ohjaajalla on ammatillista asiantuntemusta alalta, jolla osaamisen kehittäminen tapahtuu, ja hän voi siten antaa suoraa ammatillista tukea ja toimia työntekijän oppimisresurssina. Mentori taas on henkilö, joka auttaa työntekijää hallitsemaan ja koordinoimaan käytössä olevia lukuisia oppimistilanteita, mahdollisuuksia ja -resursseja. Sekä ohjaajan että mentorin lähtökohtana on työntekijän näkökulma koulutukseen. 


\section{Oppimista tukevien erityisroolien luominen työpaikalla}

Esimerkiksi henkilöstöpäällikkö tai luottamushenkilö voidaan velvoittaa käsittelemään henkilöstön kehittämiseen liittyviä asioita säännöllisesti sopivissa kokouksissa ja tekemään säännöllisesti ehdotuksia kehitysprojekteiksi sekä ennen kaikkea huolehtimaan työpaikan koulutushankkeiden ja kehitystyön seurannasta. "Tulisieluilla” on työpaikalla epävirallinen mutta tärkeä rooli, ja tulisieluja voi syntyä esimerkiksi tiettyjen roolien institutionalisoimisen myötä. Esimerkiksi henkilöstöpäällikkö tai luottamushenkilö voi saada tehtäväkseen puhaltaa elämää tiettyihin (jatko- ja täydennyskoulutuksessa tai kehityshankkeissa esitettyihin) ideoihin, viedä niitä eteenpäin järjestelmässä ja huolehtia niiden toteutuksesta arjessa.

\section{Työpaikasta luotu ihanteellinen oppimisympäristö}

Tällä viitataan arkioppimiseen, eli vuorovaikutteiseen strategiaan, jossa osaamista kehitetään ja käytetään rinta rinnan. Vaikka tässä ei ole kyse esimerkiksi kursseilla tapahtuvasta aikuisten jatko- ja täydennyskoulutuksesta, projektissa havaittiin, että työpaikalla tarvitaan ulkopuolelta ja koulutuksista tulevaa tietoa myös silloin, kun työpaikasta on luotu mitä ihanteellisin oppimisympäristö, jossa on kehittyneet tiedonvaihdon rakenteet ja toimintatavat.

Yleisesti voidaan Henrik Holt Larsenin (2002, p. 12) tapaan todeta, että tämä oppimismalli korostaa kuhunkin työhön, ihmisten ja töiden vuorovaikutukseen sekä ihmisten ja organisaation vuorovaikutukseen sisältyviä oppimismahdollisuuksia.

Seuraavat tekijät ovat luonteenomaisia työpaikan hyvälle oppimisympäristölle:

1 Työtehtävät on järjestetty niin, että ne tukevat oppimista, eli

- työssä on vaihtelua sen suhteen, mitä, miten, keiden kanssa, missä ja milloin työtehtäviä suoritetaan

- työtehtävät ovat haasteellisia suhteessa työntekijän edellytyksiin

- työntekijät saavat palautetta tekemästään työstä

- työn tulkinnassa ja suorittamisessa on autonomiaa (vapausasteita)

- työtehtäviä delegoidaan

- työntekijöillä on mahdollisuus luoda kokonaiskuva

- työntekijät voivat oppia virheistään.

2 Jokapäiväiseen työhön liittyvää oppimista tuetaan esimerkiksi

- kokouksissa, joissa vaihdetaan kokemuksia ja reflektoidaan

- opastuksen, kollegan, mentorien ja vastaavien avulla 
- kehitysprojekteilla

- kysyntälähtöisillä koulutustoimenpiteillä.

3 Työpaikalla on oppimiskulttuuri, jolle on luonteenomaista

- avoimuus ja luottamus ahdistuneisuuden tai epävarmuuden sijasta

- aloitteellisuuden ja riskinoton tukeminen

- erilaisuuksien, epävarmuuden ja virheiden sietäminen

- vaihtoehtoisten ajattelutapojen tukeminen sekä omaksuttujen ajatteluja työskentelytapojen haastaminen.

4 Työpaikan toiminta on organisoitu sekä tuotantoa että oppimista (kehitystä) tukevaksi, mikä edellyttää mm. sitä, että oppimis- ja kehitystoimintoihin varataan riittävästi aikaa ja resursseja. Jotkin organisaatiot työllistävät vakituisesti enemmän ihmisiä kuin varsinainen tuotanto vaatisi, sillä tietty osa työvoimasta osallistuu jatkuvasti jatko- ja täydennyskoulutuspanostusten toteuttamiseen. Organisaation rakenteeseen voi myös kuulua osasto, joka vastaa koulutustoimenpiteiden seurannasta tai kehitystoimenpiteistä. Keskeistä on reflektion ja tiedon jakamisen mahdollistaminen työpaikalla.

5 Johto antaa työlle tukensa, ja sillä on riittävästi osaamista. Johdon tulisi ymmärtää työpaikan kaikilla tasoilla oppimis- ja kehitysprosessien tärkeys, ja sillä tulisi olla osaamista, jota näiden prosessien organisointi ja tukeminen edellyttävät.

Konkreettisina esimerkkeinä voidaan mainita työtehtäviin liittyvien vaatimusten toteuttaminen organisoimalla työ tuotantoryhmien kesken. Tiimiorganisaation avulla voidaan taata vaihtelu, haasteellisuus, autonomia (itsenäisyys), palauteprosessit ja mahdollisuus virheistä oppimiseen. Henkilöstön osallistaminen työpaikan kehitysprojekteihin edistää vaihtelua, haasteellisuutta, autonomiaa sekä oppimiskulttuurin kehitystä ja antaa työntekijälle mahdollisuuden saada kokonaiskuvan työpaikan toiminnasta.

Vaihtelua ja haasteellisuutta tukee yleensä myös työkierto.

\section{Konkreettisia malleja parhaista käytännöistä}

Seuraavassa viidessä mallissa toteutuu huomattava osa keskeisistä menestystekijöistä: 


\section{Malli 1:}

Työpaikan ulkopuolelle luodaan kehitysorganisaatio, joka on vuorovaikutuksessa työpaikan kanssa.

Paras käytäntö: opetus työpaikkaintervention keinona.

\section{Malli 2:}

Koulutus perustuu ammattilähtöiseen oppimiseen (yrkesbaserat lärande). Oppilaitoksen ja työpaikan välille luodaan yhteistyötä, jossa työpaikan käytäntö on lähtökohtana käytännön tiedon ja teoriatiedon yhdistämiselle, ns. Söderhamnin malli.

\section{Malli 3:}

Henkilöstökoulutus perustuu henkilöstökeskusteluissa selvitettyihin koulutustarpeisiin.

\section{Malli 4:}

Työpaikalla mahdollistetaan verkko-oppiminen ja joustava oppiminen ${ }^{22}$. Työpaikalle luodaan pienimuotoisia oppimiskeskuksia.

\section{Malli 5:}

Työpaikka tarjoaa puitteet ja oppimisympäristön, jotka mahdollistavat henkilöstön osaamisen kehittymisen. Työpaikalle luodaan oppimisjärjestelmä.

\section{Malli 5a:}

Oppimismahdollisuudet integroidaan osaksi työpaikan organisaatiota.

\section{Malli 5b:}

Työpaikan organisaatio jakaantuu kahteen rinnakkaiseen osaan: työskentelyorganisaatioon ja kehitysorganisaatioon, jotka ovat vuorovaikutuksessa keskenään. Kehitysorganisaatio on yksi työpaikan oppimisjärjestelmistä.

\footnotetext{
${ }^{22}$ Verkko-oppiminen kattaa sekä tieto- ja viestintätekniikan avulla että sen kautta tapahtuvan oppimisen. Käsite vastaa laajasti ymmärrettynä kansainvälistä käsitettä CSCL: Computer Supported Collaborative Learning.
} 


\section{Parhaiden käytäntöjen vaikutukset}

Parhaille käytännöille ovat tyypillisiä seuraavat vaikutukset:

1. Oppimistuotteet parantavat henkilöstön kykyä suoriutua konkreettisista työtehtävistä (työsuoritus). Ammatillinen erityisosaaminen kehittyy.

2. Henkilöstölle kehittyy sekä toimintaosaamista että innovatiivista osaamista - eli kykyä toimia itsenäisesti, ratkaista ongelmia ja löytää uusia ratkaisuja ongelmiin. Oppimistuotteet ovat sellaisia, että ne kehittävät sekä toimintaosaamista (suoritusosaamista) että innovatiivista osaamista.

3. Henkilöstölle kehittyy paitsi kapeampaa työpaikkasidonnaista osaamista myös laajapohjaisempaa, työntekijän voimavaroja kasvattavaa osaamista. Oppimistuotteet ovat sellaisia, että ne kehittävät molempia osaamisen alueita, eli ne kehittävät ihmistä yleisesti työntekijänä. Laajapohjaisesta osaamisesta, jonka on usein havaittu kehittyneen koulutusten myötä, voidaan mainita

- halu jättää oma jälkensä työpaikalle

- uusi luottamus siihen, että ihminen voi vaikuttaa työpaikkaan, ja kyky tehdä työpaikkaa koskevia parannusehdotuksia

- koulutusasenteiden muuttuminen, lisääntynyt kiinnostus oppimiseen

- oppimisen mieltäminen osaksi työtä

- työpaikkaa koskevan tietämyksen kasvaminen ja työpaikan kokonaisuuden hahmottaminen

- $\quad$ sosiaalisten taitojen kehittyminen, esimerkkinä tiimityön kannalta välttämättömät taidot

- paremmat valmiudet hahmottaa kokonaisuus ja ottaa vastuuta siitä (työpaikasta)

- oma-aloitteisuuden ja itseohjautuvuuden kehittyminen, jotka ovat tärkeitä ominaisuuksia tiimiorganisaatiossa

- $\quad$ henkilöstön voimaannuttaminen (empowerment), joka voidaan määritellä "oppimis- ja kehitysprosessiksi, joka lisää ihmisten (yksilöiden, ryhmien ja yhteiskunnan) kykyä hallita tekijöitä, jotka mielletään merkityksellisiksi oman terveyden ja elämänlaadun kannalta” (LHA I: Eikeland 2006).

4. Oppimisen tuoma osaaminen ei näy vain yksilötasolla, vaan myös organisaation kehittymisenä, mikä voi tarkoittaa esimerkiksi tehokkuuden lisääntymistä, työpaikan oppimiskulttuurin kehittymistä sekä keskustelevan ja vuoropuhelupainotteiden yhteistyötavan syntymistä. Esimerkkeinä voidaan mainita 
- avoimuuskulttuurin kehittyminen, jolloin työntekijät suhtautuvat avoimesti työpaikan tulevaan kehitykseen sekä siihen osallistumiseen ja sitoutumiseen

- työpaikan koko tuotannon ja talouden kehittyminen

- työn sekä oppimis- ja kehitysprosessien yhdistyminen

- keskustelevan ja vuoropuhelulähtöisen työskentelytavan kehittyminen

- $\quad$ työpaikan tavoitteiden selkiytyminen koko henkilöstölle yksittäisen työntekijän mahdollisuus tiedostaa, miten hän voi edistää tavoitteiden toteutumista

- oppimisjärjestelmän syntyminen työpaikalle

- työpaikan optimoiminen oppimisympäristönä.

\section{Suositukset:}

- Aikuiskoulutuslaitosten ja henkilöstön osaamisen kehittämistä suunnittelevien työpaikkojen välille tulisi luoda nykyistä tiiviimpää yhteistyötä.

- Työpaikan osaamisen kehittäminen voi olla hyvinkin monipuolista. Kyseeseen voivat tulla pysyvät panostukset, jolloin aikuiskoulutuslaitos tarjoaa verkko-oppimiseen ja monimuoto-oppimiseen (tietokoneavusteisen oppimisen ja sosiaalisten oppimistoimenpiteiden yhdistelmään) perustuvan pysyvän tukijärjestelmän, jota työpaikalla hyödynnetään. Kyseeseen voi tulla myös yksittäinen opetusjakso, joka toteutetaan interventiotarkoituksessa ja jossa yhdistyvät opetus ja organisaatiokehitys. Lisäksi kyseeseen voi tulla konsultin antama koulutustuki, jolla edistetään optimaalisen oppimisympäristön kehittämistä työpaikalle. Esimiehille voidaan niin ikään tarjota erilliskoulutusta, joka antaa eväitä henkilöstön osaamisen kehittämishankkeiden toteuttamiseen ja ohjaamiseen.

- Aikuiskoulutuslaitoksilla tulisi olla nykyistä paremmat mahdollisuudet tehdä työpaikkojen kanssa yhteistyötä, joka liittyy joustaviin ja työpaikan tarpeisiin rääälöityihin opetus- ja oppimisjaksoihin. Tämä vaatii sitä, että aikuiskoulutuslaitoksille tarjotaan edellytyksiä ja että niitä rohkaistaan kannustinjärjestelmän avulla luomaan joustavia ja työpaikkalähtöisiä oppimisjaksoja ja että laitosten organisaatiota kehitetään uusien tehtävien hoidon tehostamiseksi.

- Aikuiskoulutuslaitosten henkilöstön tulisi itsekin osallistua osaamisen kehittämisjaksoihin, jotka antavat heille eväitä tehdä läheistä yhteistyötä työpaikoilla ja niiden kanssa henkilöstön osaamisen kehittämiseksi.

- Aikuiskoulutuslaitosten tulisi kehittää valmiuksiaan tarjota esimieskursseja, joilla pyritään kehittämään työpaikkojen esimiesten ja 
koulutusvastaavien pedagogisia kykyjä, kuten valmiuksia luoda työpaikan organisaatiosta optimaalinen oppimisympäristö.

- Työpaikan esimiesten ja koulutusvastaavien tulisi suuntautua nykyistä selkeämmin työntekijöiden osaamisen kehittämiseen mm. luomalla verkostoja asiaan perehtyneiden työpaikkojen ja koulutusten tarjoajien kanssa.

- Aikuiskoulutuslaitoksilla näyttää olevan "tavarantoimitusvaikeuksia", kun on kyse organisaatioiden tarvitsemasta uusimmasta teknisestä tietämyksestä. Aikuiskoulutuslaitosten tulisikin tiivistää tekniikkaan liittyvää yhteistyötä teknisten yliopistojen kanssa (tutkimuskytkös) ja vastaavaa pedagogiaan liittyvää yhteistyötä koulutustutkimusta tekevien yliopistojen kanssa. Tutkimuslaitosten, koulutuslaitosten ja työpaikkojen välisen yhteistyön, tiedonjaon ja tiedon tuottamisen lisääminen näyttäisi tarjoavan monia uusia näkökulmia.

\section{Viitteet}

Eikeland Olav ja Anne Marie Berg (1997): Medvirkningsbasert organisasjonslæring og utviklingsarbeid i kommunene. Oslo. Kommuneforlaget.

Eikeland Olav, Liv Hanson Ausland et al. (2006): Har systematisk læring på arbeidsplassen noe med livsfase- og seniorpolitikk å gjøre? Rapportering fra Forsøks- og Utviklingsprosjektene i Nasjonalt Krafttak for seniorpolitikk i arbeidslivet (2001-2005).

Finansministeriet: Livslang opkvalificering og uddannelse for alle på ar- bejdsmarkedet - rapport fra Trepartsudvalget - Bind 1: Den fremtidige voksen- og efteruddannelsesindsats. Julkaistu 7.2.2006.

Holt Larsen, H. et al. (2002). Læring på jobbet. Et Overblick. KL ja KTO.

Andersen, V., Clematide, B. ja Høyrup, S.: Arbejdspladsen som læringsmiljø. Learning Lab Denmark, Roskilde Universitetsforlag, 2004. Varsinkin artikkeli:

Steen Høyrup: Læringsformer, refleksionsprocesser og læringsrum i arbejdslivet, s. 73-98. 